\title{
APLICAÇÃO E ANÁLISE DE UMA SEQUÊNCIA DIDÁTICASOBRE FRAÇÕES NO \\ ENSINO FUNDAMENTAL II
}

\author{
RONEY LIMA DO NASCIMENTO
}

\section{DISSERTAÇÃO APRESENTADA AO INSTITUTO DE MATEMÁTICA E ESTATÍSTICA DA UNIVERSIDADE DE SÃO PAILO PARA OBTENÇÃO DO TÍTULO DE MESTRE EM CIÊNCIAS}

Programa: Mestrado Profissional em Ensino de Matemática

Orientador: Professor Dr. Antonio Carlos Brolezzi 


\section{APLICAÇÃO E ANÁLISE DE UMA SEQUÊNCIA DIDÁTICA SOBRE FRAÇÕES NO ENSINO FUNDAMENTAL II}

RONEY LIMA DO NASCIMENTO

SÃO PAULO

FEVEREIRO DE 2018 


\section{RESUMO}

NASCIMENTO, R. L. Aplicação e análise de uma sequência didática sobre frações no ensino fundamental II. 2018. Dissertação (Mestrado) Instituto de Matemática e Estatística, Universidade de São Paulo, São Paulo, 2018.

O presente trabalho tem como objetivo trazer uma proposta de aplicação de uma sequência didática para o ensino de frações no fundamental II, utilizando uma narrativa com elementos históricos para motivar os alunos a participarem da sequência. Apresentamos tambem algumas discussões sobre a pertinência do ensino das frações na atualidade, tendo como argumentos de partida alguns trabalhos apresentados por matemáticos, como Peter Hilton e Carlos Roberto Vianna. que discutiram existir a possibilidade da retirada das frações do currículo escolar. Utilizaremos uma abordagem histórica e conceitual das frações, através de duas dimesões temporais, a historiográfica e a dos tempos atuais, mostrando assim sua importância histórica. Baseamo-nos nos diferentes significados das frações: parte-todo, medida, quociente e operador multiplicativo. Por fim, oferecemos uma estratégia para que a aprendizagem de frações aconteça de forma conceitual e significativa. Tal estratégia foi elaborada através da análise teórica e da construção de uma sequência didática (SD), baseada nos princípios das situações didáticas de Guy Brousseau ("Teoria da Situação Didática”). A sequência foi utilizada em turmas do $6^{\circ}$ ano do ensino básico. Buscamos, com isso, criar um ambiente de motivação para aprendizagem da matemática e, ao mesmo tempo, conceder significado aos conhecimentos relacionados às frações.

Palavras-chave: Ensino de Matemática, Frações, História das frações. 


\begin{abstract}
NASCIMENTO, R. L. Application and analysis of a didactic sequence on fractions in elementary education II. 2018. Dissertation (Master degree) Institute of Mathematics and Statistics, University of São Paulo, São Paulo, 2018.

The present work aims to bring a proposal for the application of a didactic sequence for the teaching of fractions in the fundamental II segment, using a narrative with historical elements to motivate the students to participate in the sequence. We present some discussions about the pertinence of the teaching of fractions in the present time, starting with research presented by mathematicians such as Peter Hilton and Carlos Roberto Vianna, who discussed the possibility of the removal of fractions from the school curriculum. We will use a historical and conceptual approach of the fractions, through two temporal dimensions, the historiographic one and the one of the present times, thus showing its historical importance. We are based on the different meanings of fractions: part-whole, measure, quotient and multiplicative operator. Finally, we offer a strategy for the learning of fractions to happen in a conceptual and meaningful way, being so that such strategy was elaborated through the theoretical analysis and elaboration of a didactic sequence (SD) based on the principles of didactic situations offered by Guy Brousseau (Theory of Didactic Situation). The sequence was used in classes of the 6th grade of the elementary school.. We seek to create a motivational environment for learning mathematics, at the same time giving meaning to the knowledge related to fractions.
\end{abstract}

Key-words: Mathematics teaching, Fractions, History of fractions. 


\section{SUMÁRIO}

MOTIVAÇÃO. 07

1, INTRODUÇÃO

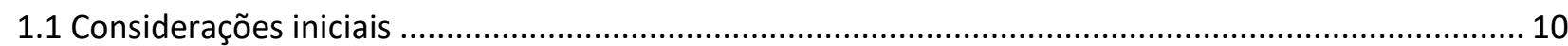

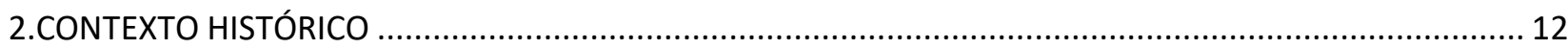

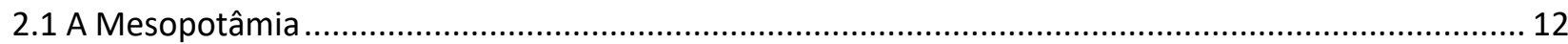

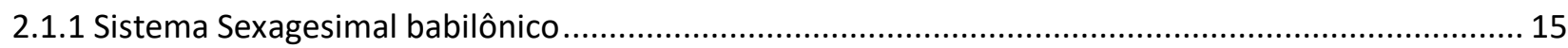

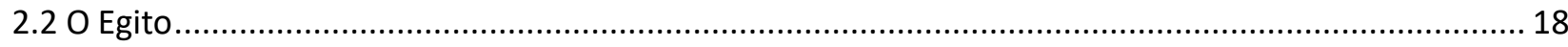

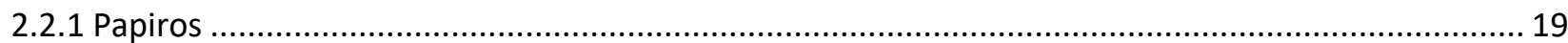

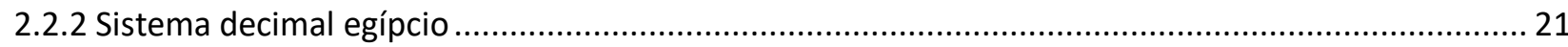

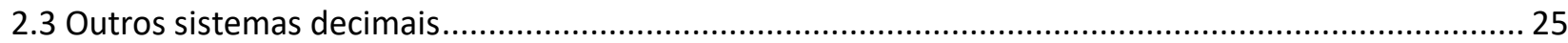

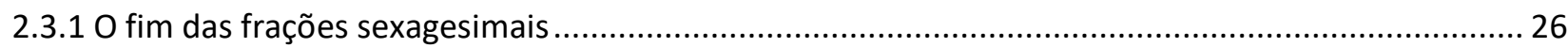

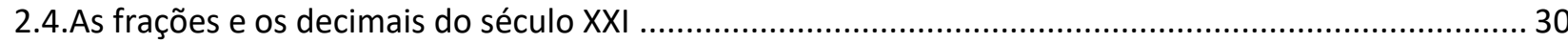

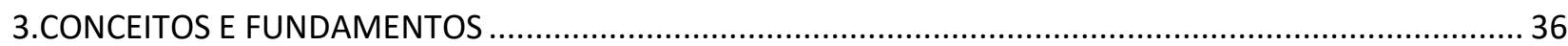

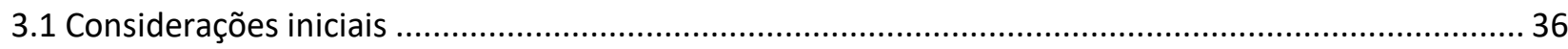

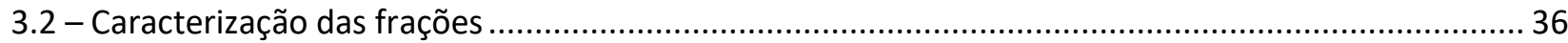

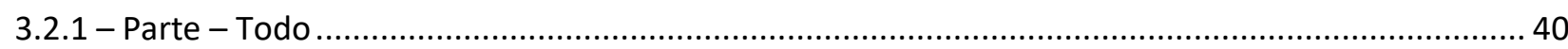

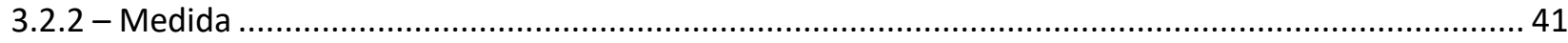

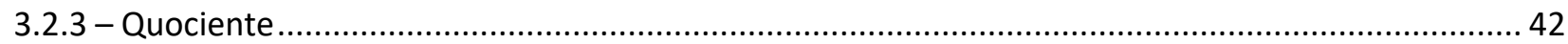

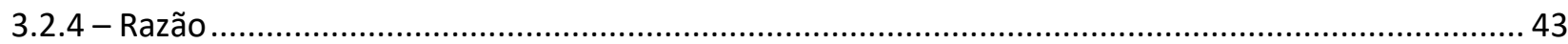

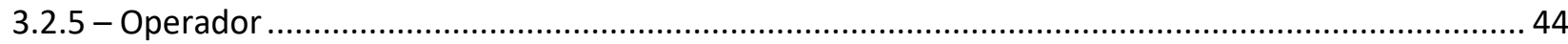

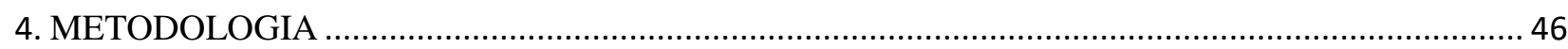

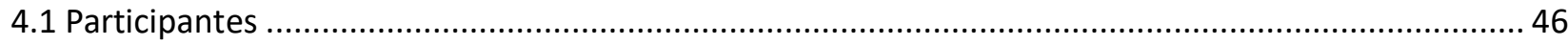

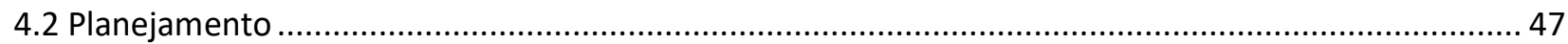

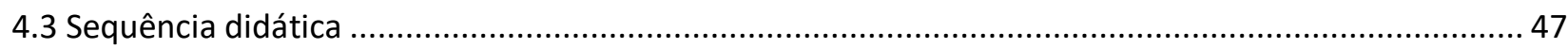

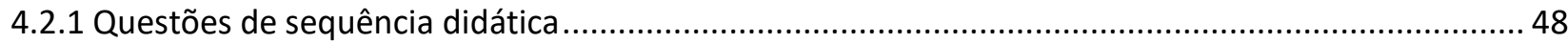

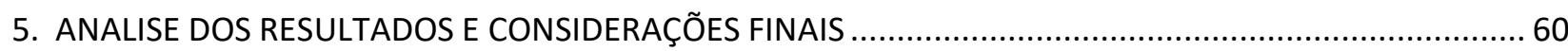

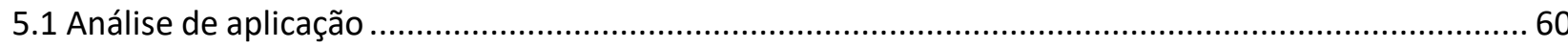

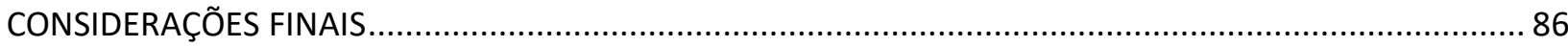

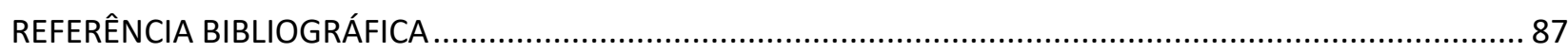

ANEXOS 


\section{LISTA DE FIGURAS}

Figura 1: O tablete Plimpton 322

Figura 2: Sistema Sexagesimal babilônico

Figura 3: Tablete sumério YBC7289

Figura 4: Papiro Rhind

Figura 5: Sistema de numeração egípcio

Figura 6: Representação das frações egípcias.

Figura 7: François Viéte

Figura 8: Simon Stevin

Figura 9: Decimais no posto de gasolina

Figura 10: Arredondamento ABNT

Figura 11: Cálculo de PTAX

Figura 12: Notas do Tesouro Nacional

Figura 13: Receita de bolo de chocolate

Figura 14: Exploração dos significados de fração PCN

Figura 15: Esquema de gênese histórica dos números fracionários

Figura 16: Fração 7/9

Figura 17: Fração 1/2

Figura 18: Problema envolvendo a noção de medida

Figura 19: Concepção de quociente, problema dos chocolates e das crianças

Figura 20: Uso de razões em problemas com fração

Figura 21: Problema com concepção de operador

Figura 22: Questão 1

Figura 23: Questão parte-todo

Figura 24: Questão 2

Figura 25: Questão parte-todo proposta por Silva

Figura 26: Questão 3

Figura 27: Questão de medida proposta por Silva

Figura 28: Questão 4

Figura 29: Questão de medida - reconstituição da unidade

Figura 30: Questões 5 e 6

Figura 31: Questão de concepçao de quociente

Figura 32: Questões 7 e 8 
Figura 33: Questão determinar uma razão

Figura 34: Questão 9

Figura 35: Operador fracionário

Figura 36: Questão 10

Figura 37: Resolução do aluno D questão 1

Figura 38: Resolução do aluno B questão 1

Figura 39: Resolução na lousa aluna $S$

Figura 40: Resolução da questão 2 - aluno C

Figura 41: Resolução da questão 2 - Aluno A

Figura 42: Resolução na lousa questão 2

Figura 43: Resolução da questão 3 - Aluno G

Figura 44: Resolução da questão 3 - Aluna $S$

Figura 45: Resolução da questão 3 - Aluno M

Figura 46: Resolução da questão 4 - Aluno E

Figura 47: Resolução da questão 4 - Aluno H

Figura 48: Resolução da questão na lousa

Figura 49: Resolução das questões 5 e 6 - Aluno D

Figura 50: Resolução das questões 5 e 6 - Aluna $S$

Figura 51: Resolução na lousa da questões 5 e 6 - Aluno B

Figura 52: Questões 7 e 8 - Papiro

Figura 53: Resolução das questões 7 e 8 - Aluna L

Figura 54: Resolução das questões 7 e 8 - Aluna C

Figura 55: Resolução das questões 7 e 8 na lousa - Aluno D

Figura 56: Resolução da questão 9 - Aluno G

Figura 57: Resolução da questão 9 - Aluno F

Figura 58: Resolução da questão 10 - Aluno H

Figura 59: Resolução da questão 10 - Aluno L 


\section{Motivação}

Ao ensinar matemática na escola básica, o professor se depara com situações bastante intrigantes. Em 2014, enquanto professor em uma escola pública localizada na periferia de São Paulo, após selecionar alguns exercícios para os alunos, um grupo me solicitou pois haviam terminado os exercícios. Isto foi uma surpresa, pois haviam resolvido em tempo muito menor do que o estimado. Buscando entender como haviam procedido, recolhi e observei as anotações; percebi que os alunos não tinham utilizado em nenhum dos exercícios as ideias de operações com frações oferecidas previamente, mas faziam a divisão imediatamente mentalmente e se propunham a resolver tudo com a forma decimal. Um exemplo é um exercício no qual os alunos deveriam somar as frações um meio e um terço, procedendo da seguinte maneira:

$$
\frac{1}{2}+\frac{1}{3}=0,500+0,333 \ldots=0,833 \ldots
$$

Alguns alunos começaram a questionar a real necessidade de se trabalhar com a forma de fração já que seria muito mais fácil trabalhar em forma decimal, segundo eles. Estas perguntas foram motivadas por colegas de classe que começaram a exibir seus resultados dizendo que não precisariam pensar em cálculos utilizando ideias de denominador comum e muito menos mínimo múltiplo comum. Apesar de haver alertado anteriormente quanto ao risco de se trabalhar com as dízimas periódicas, ou seja, saber que nós, apesar de fazermos com frequência, não poderíamos somar números que estão na forma de dizima periódica, alguns alunos foram incisivos e decidiram usar somente as frações em números escritos sob a forma decimal. Esta situação me levou a refletir sobre a possibilidade da retirada das frações do currículo escolar, sendo a motivação inicial desta dissertação.

Na maioria das sociedades contemporâneas não encontramos exemplos do uso de frações na nossa rotina, seja nos meios de comunicação, no comércio ou mesmo nas calculadoras. Assim sendo, porque existe uma ênfase no ensino das frações nos currículos de matemática?

Em 1980 o matemático britânico Peter John Hilton publicou o artigo "Do We Still Need Fractions in the Elenmentary Curriculum?" ("Ainda precisamos de frações no currículo do ensino fundamental?”, em uma tradução livre) (Hilton, 1980), traduzido posteriormente pelos pesquisadores Elza Furtado Gomide, que foi professora doutora do Instituto de Matemática e Estatística da Universidade de São Paulo e foi a primeira 
doutora em matemática no Brasil, e pelo professor Seiji Hariki. O artigo, conforme explicitado em seu título, avança em um tema que foi debatido posteriormente por outros pesquisadores como o professor Carlos Roberto Vianna, em cujo artigo "A Hora da Fração: pequena sociologia dos vampiros na Educação Matemática”, explicita objetivamente sua defesa pelo "[...] extermínio das frações, sua retirada dos currículos, dos livros didáticos, das listas de conteúdo escolar." (VIANNA, 2008, p. 162). Complementarmente, a professora doutora Célia Maria Carolino Pires em seu livro "Currículos de Matemática: da Organização Linear a Ideia de Rede" também questiona a relevância das frações na vida cotidiana:

Ultimamente, tem-se discutido que a necessidade de lidar com desenvoltura com as frações na vida comum limita-se às metades, terços, quartos, doze avos etc.; o restante das frações raramente se apresenta e as divisões entre as frações quase nunca aparecem. Além disso, a implantação do sistema métrico decimal nos países anglosaxões aumentou ainda mais a polemica e, de certo modo, reforçou a tese de que o ensino deve dedicar-se às representações decimais. (PIRES, 2000, p. 177).

Diante deste debate acerca da relevância do ensino deste conceito, este trabalho visa elaborar e aplicar uma sequência didática tendo frações como tema central. Conforme será apresentado na metodologia. esta proposta de ensino é apoiada nas instruções oferecidas por Guy Brousseau, e pretende ser trabalhada com alunos de uma escola particular do Estado de São Paulo. Para tal, este estudo se divide em 5 capítulos. O primeiro traz a introdução e os objetivos da pesquisa; o segundo apresenta o contexto histórico do uso e ensino das frações; o terceiro capítulo trata dos conceitos e fundamentos referentes a frações; o quarto capítulo descreve a metodologia utilizada; enquanto o quinto e último capítulo traz os resultados obtidos e sua análise. 


\section{INTRODUÇÃO}

\subsection{Considerações iniciais}

As discussões sobre ensino e aprendizagem em diversas áreas do conhecimento fazem parte de um capítulo antigo na história da educação. Por exemplo, conforme nos mostra Fernandes (2001), o termo didática (do grego didaktiké), que significa "arte de ensinar foi utilizado pela primeira vez pelo educador e psicólogo alemão Wolfgang Ratke (1571-1635), em 1629, em seu livro "Principais aforismas didáticos". Contudo, o termo foi consagrado pelo bispo, educador, escritor e cientista tcheco João Amós Comênio. Para ele, a educação deve ser universal e deve-se ensinar tudo a todos. Esta ideia é defendida por Comênio em seu livro "Didática Magna”, publicado em 1657.

Entre os séculos XVII e XIX, não encontramos relatos sobre estudos direcionados ao ensino da matemática, com isso trazemos nosso olhar para o ano de 1908, quando o ensino de matemática foi tema do IV Congresso Internacional de Matemática, realizado em Roma.

Neste encontro quadrienal foi criada a Comissão Internacional para o Ensino de Matemática (CIEM), cuja missão envolvia

a aprovação de uma proposta para que os países participantes informassem como estava o ensino de Matemática, em especial na escola secundária [e cuja criação] marcou o início da primeira fase do movimento pela modernização da Matemática. (CLARAS e PINTO, 2008, p. 4622)

Esta modernização era compreendida como uma necessidade grande de que os trabalhadores tivessem condições de acompanhar o desenvolvimento tecnológico que estava emergindo. Os matemáticos que compunham o comitê organizador da CIEM eram o alemão Felix Klein, o suíço Henri Ferh e o inglês George Greenhill (VALENTE, 2004).

Desde então foram vários os esforços para melhor organizar o ensino de Matemática no mundo, para isso muitos matemáticos participavam dos congressos existentes propondo melhorias no ensino da matemática. O presidente do comitê, Felix Klein (1849-1925), de acordo com relatos de Valente (2004, p. 29) tinha motivação 
particular para se engajar em assuntos escolares. Ele era geômetra, organizador, administrador e reestruturou a matemática alemã.

Não muito tempo depois na França no final da década de 1960, surgia o IREM (Instituto de Investigação do Ensino da Matemática), nas palavras de Pommer,

em seus primórdios o IREM desenvolvia uma complementação na formação de professores de matemática e na produção de meios materiais de apoio para a sala de aula, tais como textos, jogos, brinquedos, problemas, exercícios e experimentos de ensino. (POMMER, 2008, p. 1)

Um dos pesquisadores citado por Pommer (2008) é o matemático francês Guy Brousseau, que contribuiu desenvolvendo a teoria das situações didáticas. Esta teoria é composta por algumas etapas que o professor deve realizar para que aconteça de fato a aprendizagem de algum assunto matemático. Essas fases são: devolução, ação, reformulação, validação e institucionalização. No referencial teórico faremos uma análise mais profunda sobre cada etapa.

Podemos considerar que o ensino da matemática ainda não atingiu níveis de excelência - principalmente observando o caso do Brasil. Pensando na atualidade e tomando como base indicadores como o Programa Internacional de Avaliação de Alunos (PISA) que em sua última realização em 2015 mostra que o país ficou na $66^{\circ}$ posição em matemática, estando abaixo do nível adequado para a compreensão e resolução de problemas de matemática. Com o objetivo de contribuir para o ensino da matemática, esta dissertação oferece e aplica uma sequência didática elaborada com o apoio da teoria desenvolvida por Brousseau, analisando seus resultados. Usaremos a história como motivador para os alunos que precisam compreender os conceitos de frações e suas raízes. 


\section{CONTEXTO HISTÓRICO}

\subsection{A Mesopotâmia}

As histórias que contam a origem das frações podem ser encontradas em diversos autores de livros de história da matemática como Eves, Boyer e Roque. Claramente, antes de surgirem as frações na história tivemos outros acontecimentos, para que então pudéssemos necessitar de tal forma de medida.

Para uma melhor aproximação entre acontecimentos importantes da história da matemática no que posteriormente poderá levar-nos ao surgimento das ideias relacionadas a fração, Roque (2012) nos diz que

\footnotetext{
A palavra "mesopotâmia", que em grego quer dizer "entre rios", designa mais uma extensão geográfica do que um povo ou uma unidade política. Entre os rios Tigre e Eufrates, destacavam-se várias cidades que se constituíam em pequenos centros de poder, mas também passavam por ali povos nômades, que, devido à proximidade dos rios, acabavam por se estabelecer. Dentre os que habitaram a Mesopotâmia estão os sumérios e os acadianos, hegemônicos até o segundo milênio antes da Era Comum. As primeiras evidências de escrita são do período sumério, por volta do quarto milênio a.E.C. Em seguida, a região foi dominada por um império cujo centro administrativo era a cidade da Babilônia, habitada pelos semitas, que criaram o Primeiro Império Babilônico. (ROQUE, 2012, p. 36).
}

Seguindo esse caminho pela história da matemática, nas palavras de Roque (2012) "Os semitas são conhecidos como os "antigos babilônicos", e não se confundem com os fundadores do Segundo Império Babilônico, denominados "neobabilônicos". Data do período babilônico antigo (2000 - 1600 a.E.C.) a maioria dos tabletes de argila mencionados na história da matemática”.

Entre os tabletes que temos os registros nos dias atuais, um dos mais comentados com certeza é o Plimpton 322, que é uma placa que faz parte da coleção da Universidade de Columbia e que foi catalogada com o número 322, acredita-se que esse tablete tenha sido escrito entre os anos (1900 - 1600 a.C.), mas ainda nos dias atuais existem diversos historiadores que divergem sobre o que realmente estaria escrito nesse tablete, na interpretação de Neugebauer (1899 - 1990) “Trata-se de um tablete disposto em quatro 
colunas, sendo a última a numeração das linhas. As outras três colunas representam relações sobre soluções com números inteiros positivos da equação $a^{2}+b^{2}=c^{2}$, ou seja, trata-se do que é denominado ternos pitagóricos. "

No ano de 2017 pesquisadores da University of New South Wales (UNSW), descobriram que o tablete plimpton 322 descreve os formatos de triângulos retângulos utilizando um novo tipo de trigonometria baseada em proporções.

Figura 1 - O Tablete Plimpton 322.

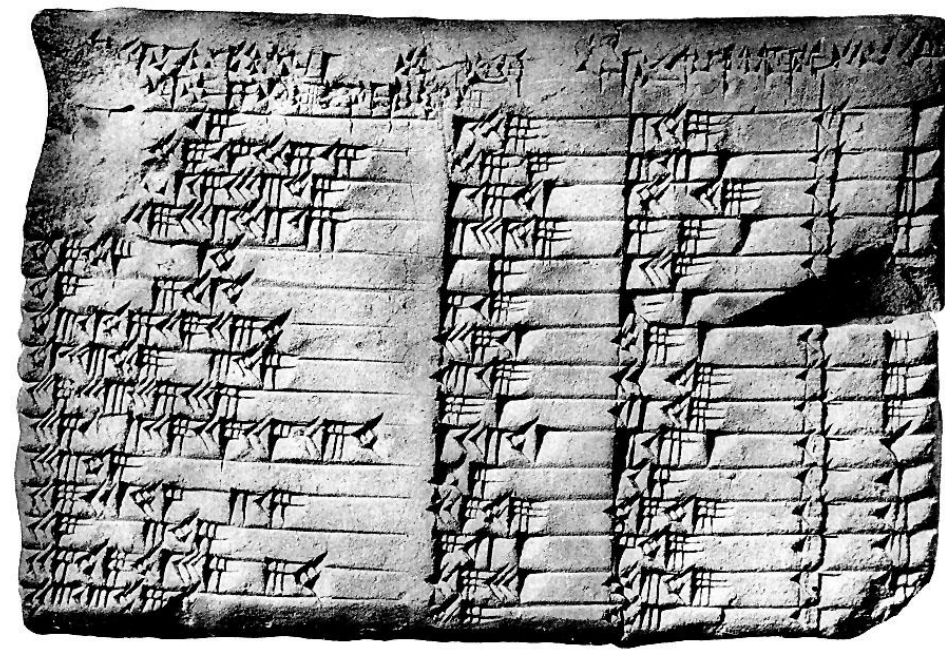

Fonte: Wikimedia, 1800 BCE.

A imagem do tablete plimpton 322 nos fornece uma possível visualização das ideias relacionadas às interpretações do que consta nele.

Daquela época até os dias atuais foram preservados milhares de textos em tabletes cuneiformes e, graças a esses tabletes, hoje podemos nos aprofundar em antigos conhecimentos matemáticos que foram se moldando ao longo do tempo. Os tabletes nos permitem elaborar analises mais detalhadas de momentos históricos,

o surgimento de civilizações caracterizadas pelo uso de metais teve lugar primeiro em vales de rios, como os do Egito, Mesopotâmia, Índia e China; por isso nós designaremos a parte mais antiga do período histórico pelo nome de "estagio potâmico". Os registros cronológicos das civilizações nos vales dos rios Indo e Yangtse não merecem confiança, mas dispomos de informações razoalvelmente seguras sobre os povos que viveram ao longo do Nilo e no crescente fértil dos rios Tigre e Eufrates. (BOYER, 2010, p. 7). 
Acredita-se que nesta época mencionada por Boyer, os homens produziam sua sobrevivência e muito disso advinha da caça e da pesca, eles organizavam-se em grupos e saiam em busca de melhores abrigos e mais comida pelo mundo, pode-se dizer que com a necessidade da agricultura e da criação de animais o homem precisou criar métodos de partir coisas ou talvez métodos para que pudessem fazer divisões de uma forma intuitiva.

A ideia de número é muito mais antiga do que os progressos tecnológicos como o uso de metais ou de veículos com rodas. Precede a civilização e a escrita, no sentido usual da palavra, pois artefatos om significado numérico, [...] vêm de um período carca de trinta mil anos atrás. (Boyer,2010 p.3). Assim como a ideia de número, "o conceito de número inteiro é o mais antigo na matemática e a sua origem se perde nas névoas da antiguidade pré-histórica (BOYER, 2010, p.4).

Nesses estudos mencionados por Boyer (2010), seguiremos dos inteiros citados acima em busca dos racionais, ou de formas em que os racionais fossem apresentados na época. Nas palavras de Boyer (2010):

A noção de fração racional, porém, surgiu relativamente tarde e em geral não estava relacionada de perto com os sistemas para os inteiros. Entre as tribos primitivas parece não ter havido praticamente nenhuma necessidade de usar frações. Para necessidades quantitativas o homem prático pode escolher unidades suficientemente pequenas para eliminar a necessidade de usar frações. Portanto não houve um progresso ordenado de frações binárias para quinarias para decimais, e as frações decimais foram essencialmente um produto da idade moderna da matemática, não do período primitivo" (BOYER, 2010, p.4 )

Com isso Boyer nos leva a entender que as sociedades primitivas não precisavam do uso de frações, corrobora essa ideia Almeida (2011) que diz

De modo geral parece que as sociedades primitivas não necessitam do uso de frações. O problema de dividir 20 conchas por 5 pessoas, ou seja, encontrar $1 / 5$ de 20, pode ser resolvido, construindo-se 5 montes (iguais) com as 20 conchas, obtendo-se 4 conchas para cada um. Para suas necessidades 
quantitativas, o homem prático pode escolher unidades suficientemente pequenas, dispensando o trabalho com frações. Portando as sociedades primitivas podem efetuar contas (adição, subtração, multiplicação e divisão) com o auxílio de contadores, dentro de certo limite, sem terem noção dos fundamentos lógicos desses procedimentos.” (ALMEIDA, 2011, p. 39).

Sendo assim em algumas sociedades não haviam problemas para os quais fosse necessário a criação das frações, pois bastava que se fizesse determinadas divisões para obter soluções inteiras.

\subsubsection{Sistema Sexagesimal babilônico}

Acredita-se que uma das grandes vantagens dos babilônicos era o seu sistema sexagesimal posicional, ou seja, um mesmo símbolo pode significar diferentes quantidades quando colocado em determinada posição, nas palavras de Roque (2012).

Nosso sistema de numeração de base 10 também é posicional. Há símbolos diferentes para os números de 1 a 9, e o 10 é representado pelo próprio 1 mas em uma posição diferente. Por isso se diz que nosso sistema é um sistema posicional de numeração de base 10, o que significa que a posição ocupada por cada algarismo em um número altera seu valor de uma potência de 10 para cada casa à esquerda. (ROQUE, 2012, p.50).

Seguindo a mesma linha de raciocínio Roque (2012) explica uma diferença entre o nosso sistema e o dos babilônicos, conforme citação a seguir.

\footnotetext{
Uma diferença entre o nosso sistema e o dos babilônios é que estes empregavam um sistema aditivo para formar combinações distintas de símbolos que representam os números de 1 a 59, enquanto o nosso utiliza símbolos diferentes para os números de 1 a 9 e, em seguida, passa a fazer uso de um sistema posicional. Em nosso sistema de numeração, no número decimal 125 o algarismo 1 representa 100; o 2 representa 20; e o 5 representa 5 mesmo. Assim pode-se escrever que $125=1 \times 10^{2}+2 \times 10^{1}+$ $5 \times 10^{\circ}$. (ROQUE, 2012, p. 50).
}

Para exemplificar as diferenças mencionadas, vejamos a imagem abaixo: 
Figura 2 - Sistema sexagesimal babilônico

\begin{tabular}{|c|c|c|c|c|c|c|c|c|c|}
\hline Y & 1 & $\pi$ & 2 & $\pi$ & 3 & Af & 4 & W & 5 \\
\hline m & 6 & W & 7 & $\mathrm{~mm}$ & 8 & & 9 & 4 & 10 \\
\hline $4 \mathrm{I}$ & 11 & $4 \pi$ & 12 & $4 \mathrm{~m}$ & 13 & $4 \pi$ & 14 & $\triangleleft \Psi$ & 15 \\
\hline$<m$ & 16 & $4 m$ & 17 & $4 \mathrm{~m}$ & 18 & 4 开 & 19 & 44 & 20 \\
\hline$\ll<T$ & 21 & $44 \pi$ & 22 & $44 \mathrm{~m}$ & 23 & 44 & 24 & 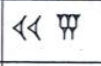 & 25 \\
\hline$\ll<m$ & 26 & $44 \mathrm{~W}$ & 27 & $44 \mathrm{~mm}$ & 28 & 44 & 29 & 低 & 30 \\
\hline 低 Y & 31 & 低 II & 32 & \&A IT & 33 & \& & 34 & 《K & 35 \\
\hline 低 $\mathrm{m}$ & 36 & 低 & 37 & 低 & 38 & 低开 & 39 & $\$$ & 40 \\
\hline 《U & 41 & 将 $\pi$ & 42 & 将 II & 43 & $\$$ & 44 & 蒋W & 45 \\
\hline 出州 & 46 & 然界 & 47 & 多 & 48 & $\$$ & 49 & 梦 & 50 \\
\hline 糸 Y & 51 & 然 $\pi$ & 52 & 然 III & 53 & 梦 & 54 & 然 W & 55 \\
\hline 热 & 56 & 然 & 57 & 然 & 58 & 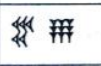 & 59 & I & 60 \\
\hline
\end{tabular}

Fonte: Retirado de (Roque, 2012, p. 49)

Na figura não notamos diferenciação entre a escrita do número 1 e do número 60 do sistema babilônico, na época eles usavam diferentes tamanhos para representar os diferentes valores, depois de algum tempo eles colocaram um símbolo para separar as posições criando assim uma espécie de zero.

O tratamento das frações, no que diz respeito à Mesopotâmia, foi superado de forma prática, pois o sistema posicional dos babilônicos os ajudavam a computar com diversos números inteiros e fracionários assim como nós os tratamos hoje em nossa base 10. Boyer (2010) relata o seguinte

[...] os que viviam "entre os dois rios" deram um passo muito feliz de estender o princípio da posição as frações. [...]. Significava que os babilônios dominavam o poder de computação que a moderna notação decimal para as frações nos confere. Para o estudioso babilônio, como para o engenheiro moderno, a adição ou a multiplicação de 23,45 e 9,876 não eram essencialmente mais difíceis que as mesmas operações entre os inteiros 2.345 e 9.876; e os mesopotâmios rapidamente exploraram essa grande descoberta. (BOYER, 2010, p.19). 
Com isso, não haveria, a não ser pela escrita numérica, diferenças significativas nos cálculos que foram apresentados na época e nos que são realizados nos dias atuais. Complementando essa ideia, Hogben (1958) nos diz que,

[...] Outro traço essencialmente moderno da matemática babilônica era o de não especificar os denominadores das frações. Eles usavam frações sexagesimais como hoje usamos as decimais; apenas não dispunham de nenhum sinal (como a vírgula) que pudesse assinalar a significação precisa de uma série de números". (HOGBEN, 1958, p. 71-72).

Sendo assim, eles conseguiam desenvolver o uso dos números racionais e seus cálculos dispondo de notações que foram suficientes para a época. Como exemplo do uso dos números racionais pelos babilônicos, temos a tableta Yale (N. ${ }^{\circ}$ 7289) que faz parte da Coleção Babilônica de Yale. Dos registros atuais acredita-se que esse seja o da representação mais antiga do valor da raiz quadrada de dois Boyer (2010). Essa peça foi descoberta em 1912 e faz parte do acervo da Universidade de Yale.

Os valores que aparecem na tableta Yale (N. ${ }^{0}$ 7289) têm uma aproximação de resultados com uma diferença de erro da ordem de $10^{-6}$. Vemos diante desses resultados que os babilônios já possuíam uma familiaridade com as frações e uma maneira de lidar com problemas envolvendo números fracionários que poucos conseguiram enxergar até os anos antes do renascimento.

Figura 3 - Tablete sumério YBC7289

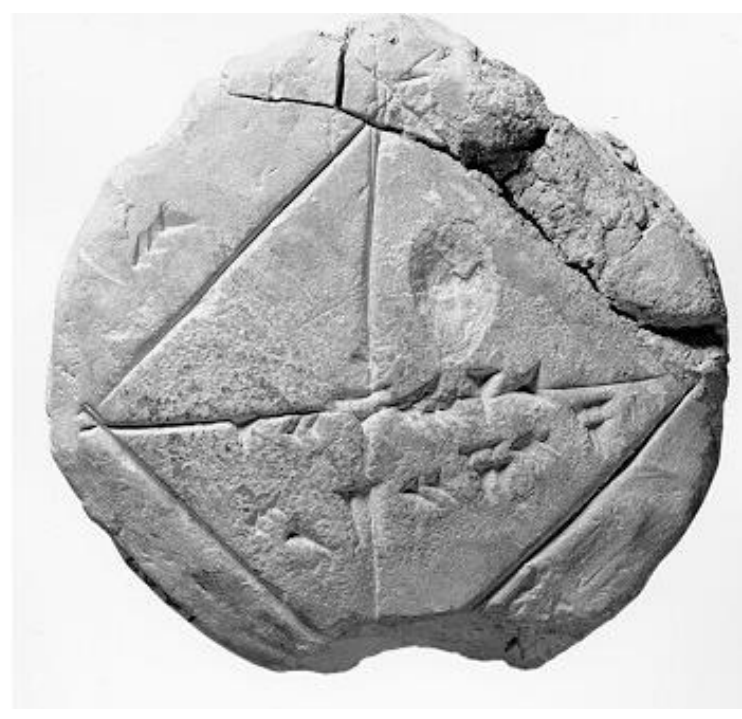

Fonte: Yale Babilonian Colection 
$\mathrm{Na}$ imagem as várias marcações representam o cálculo da raiz quadrada de dois com erro menor do que $10^{-6}$ como afirmou Boyer em seus estudos.

Os babilônios certamente fizeram uso de situações diversas envolvendo frações e por isso merecem destaque para o conhecimento das frações e também para a sua notação sexagesimal que como veremos posteriormente demorou a ser substituída por outra.

\subsection{O Egito}

A civilização egípcia antiga desenvolveu-se no nordeste africano, margens do rio Nilo (BARASUOL, 2006). O Egito é uma região com muitos desertos e por isso o rio Nilo era tão necessário para via de transportes, mercadorias e pessoas, tendo importância central na agricultura, e sendo também utilizado para consumo e pesca. Barasuol diz que:

a sociedade egípcia era dividida em várias camadas (faraó, sacerdotes, militares, escribas, camponeses, artesãos, pequenos comerciantes e os escravos). A escrita egípcia permitiu a divulgação de ideias, comunicação e controle de impostos. Existia duas formas de escrita: a demótica (mais simplificada) e a hieroglífica (mais complexa e formada por desenhos e símbolos). Utilizou-se para escrever uma espécie de papel chamada papiro que era produzida a partir de uma planta de mesmo nome. Além disso, a civilização egípcia destacou-se nas áreas de ciências, sendo a matemática usada nas construções das pirâmides, diques, canais de irrigação e estudos de astronomia. (Barasuol, 2006, p. 3).

Percebe-se a necessidade de uso da matemática no Egito através da administração, que como relatado era subdividida em vários grupos que precisavam fazer diversas anotações e medições. Pode-se dizer que o aprimoramento de determinados cálculos dos egípcios se deve também ao fato de que um erro pudesse levar a uma grande perda. Mlodinow (2006) explica que

os egípcios começaram a estabelecer comunidades fixas sobre montes de terra que se tornavam pequenas ilhas ligadas por caminhos elevados durante as 
cheias [...]. Como muita coisa estava em jogo, os egípcios desenvolveram métodos bastante confiáveis, embora tortuosos, para calcular a área de um quadrado, de um retângulo e de um trapezoide. (MLODINOW, 2010, p.53).

Então devido a essa necessidade de medir com precisão, os egípcios foram construindo melhores formas de cálculos de áreas e volumes.

\subsubsection{Papiros}

Os papiros eram a forma que os egípcios usavam para registrar as coisas, como foi para nós o papel em algum momento, e que depois foi substituído por computadores e smartphones.

Nos estudos de Roque (2012) ela relata que "os registros disponíveis são mais numerosos para a matemática mesopotâmica do que para a egípcia, provavelmente devido à maior facilidade na preservação da argila usada pelos mesopotâmicos do que do papiro, usado pelos egípcios." (ROQUE, 2012, p. 37).

Dando continuidade às ideias apresentadas, Eves (2011) comenta que,

Os antigos egípcios inventaram um primitivo material de escrita parecido com o papel - o papiro, que por volta do ano 650 a.c. já havia sido introduzido na Grécia. Esse material era feito de um junco aquático chamado papu. Os talos desse junco eram cortados em longas e delgadas tiras que eram colocadas lado a lado para formar uma folha. Outra camada de tiras era colocada por cima e a peça era então embebida em água, após o que era imprensada e posta a secar ao sol. É provável que devido a uma goma natural da planta as camadas mantivessem-se unidas. Após a secagem as folhas eram preparadas para a escrita mediante um laborioso processo de alisamento feito com um objeto redondo e rígido. O papiro era demasiado valioso para ser usado abundantemente como simples papel rascunho. (EVES, 2011 p. 38)

Assim, poucas coisas relacionadas à matemática egípcia sobreviveram ao tempo para nos ensinar sobre seu desenvolvimento. Entre os materiais que ainda estão 
disponíveis, destaca-se o papiro Rhind (também conhecido como papiro de Ahmes Figura 4).

Figura 4-Papiro Rhind

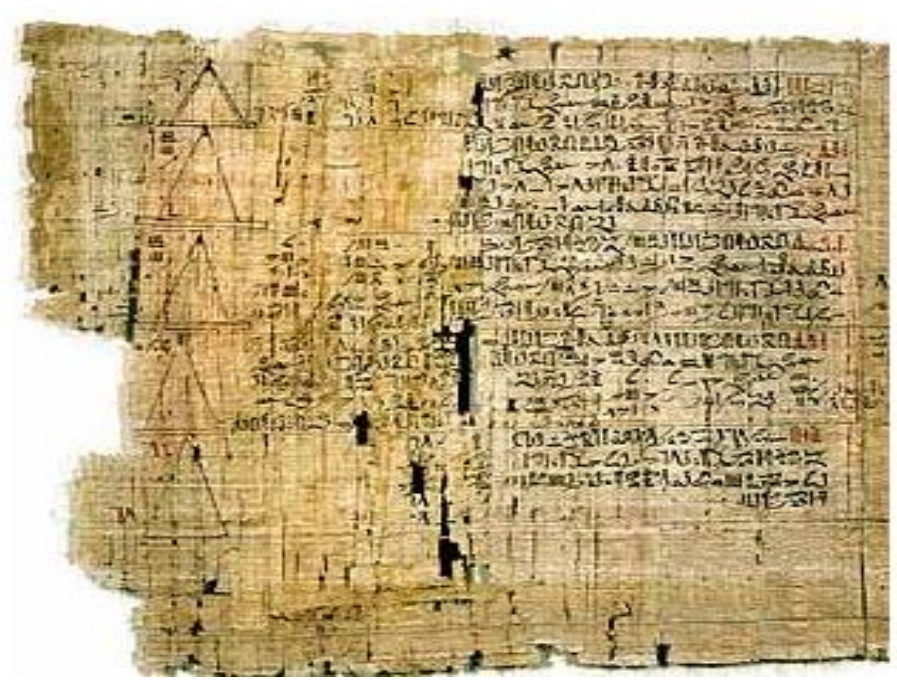

Fonte: LUCHETTA (2008)

Mostrando a história do papiro, Almeida (2011) nos diz que,

O papiro de Rhind, nossa mais importante fonte sobre a matemática egípcia, foi descoberto na metade do século passado, ao que parece nas ruinas de pequeno edifício, perto do templo mortuário de Ramsés II em Tebas. Foi adquirido em Luxor, juntamente com outras antiguidades egípcias, pelo advogado escocês Alexandre Henry Rhind, que, por suas razões de saúde, foi obrigado a passar o inverno no Egito durante as temporadas de 1855-6 e 18567. Rhind faleceu quando retornava para casa de outra visita ao Egito, em 1963, e o papiro de Rhind, bem como outro documento matemático conhecido como o rolo de couro, foram adquiridos do seu testamento em 1865 pelo Museu Britânico. O papiro de Rhind, no seu estado original, formava um rolo constituído de quatorze folhas de papiro, cada qual com cerca de $40 \mathrm{~cm}$ de comprimento e $32 \mathrm{~cm}$ de altura, coladas nas extremidades. (Almeida, 2011, p. 54). 
Os papiros então eram de difícil produção e preciosos para a população egípcia. Eves (2011) menciona que o papiro de Rhind é um texto matemático que contém 85 problemas, copiados em escrita hierática pelo escriba Ahmes a partir de um trabalho mais antigo. Eves aponta ainda para o fato de o papiro de Rhind ser uma fonte primária rica sobre a matemática egípcia antiga; descreve os métodos de multiplicação e divisão dos egípcios, o uso que faziam das frações unitárias, seu emprego da regra da falsa posição, sua solução para o problema da determinação da área de um círculo e muitas aplicações da matemática a problemas práticos.

O papiro de Rhind não foi o único a ser encontrado e estudado por historiadores de matemática: também se teve acesso aos papiros de Berlim e de Moscou. O papiro de Berlim foi comprado pelo escocês Alexandre Henry Rhind, assim como o papiro Rhind mencionado acima por Almeida (2011). Atualmente, aquele está no Museu Estatal em Berlim; já o de Moscou foi comprado pelo egiptólogo V. S. Golenishchev, que o adquiriu em 1893. Em 1917, este foi comprado pelo Museu de Belas Artes de Moscou.

O papiro de Moscou contém 25 problemas, dos quais muitos se parecem com os do Papiro Rhind - possibilitando comparações. No entanto, alguns problemas são bastante distintos, como um que se refere à área de uma superfície curva e outro que se refere à área de uma pirâmide truncada, além de problemas que resultarão na equação $2 \mathrm{x}$ $+\mathrm{x}=9$. (BECK, 2015, p. 51).

\subsubsection{Sistema decimal egípcio}

Os homens da Idade da Pedra não usavam frações, mas com o surgimento de novas culturas durante a Idade do Bronze, parece ter surgido a necessidade do conceito de fração e de notação para frações. (BOYER, 2010 p. 9).

Em relatos de historiadores acredita-se que os egípcios já haviam desenvolvido o seu sistema decimal em meados do ano 3000 a.C. o que para Roque (2012) teria acontecido antes da unificação do Egito sob o regime dos faraós. Os egípcios não possuíam um sistema de numeração posicional, diferente dos babilônicos que conseguiram criar um sistema posicional.

No entanto haviam coisas a serem aprendidas como os números egípcios, Roque (2012) afirma que,

Os números egípcios tinham características interessantes, por exemplo, o número 1 era representado por uma barra vertical, os próximos números serão 
como a soma do número de barras que corresponda ao número procurado, por exemplo o número nove será representado por nove barras verticais. em seguida os números eram múltiplos de 10, por essa razão, diz-se que tal sistema é decimal. O número 10 é uma alça; 100, uma espiral; 1 mil, a flor de lótus; 10 mil, um dedo; 100 mil; um sapo; e 1 milhão, um deus com as mãos levantadas. (ROQUE, 2012, p.21)

Figura 5 - Sistema de numeração egípcio.

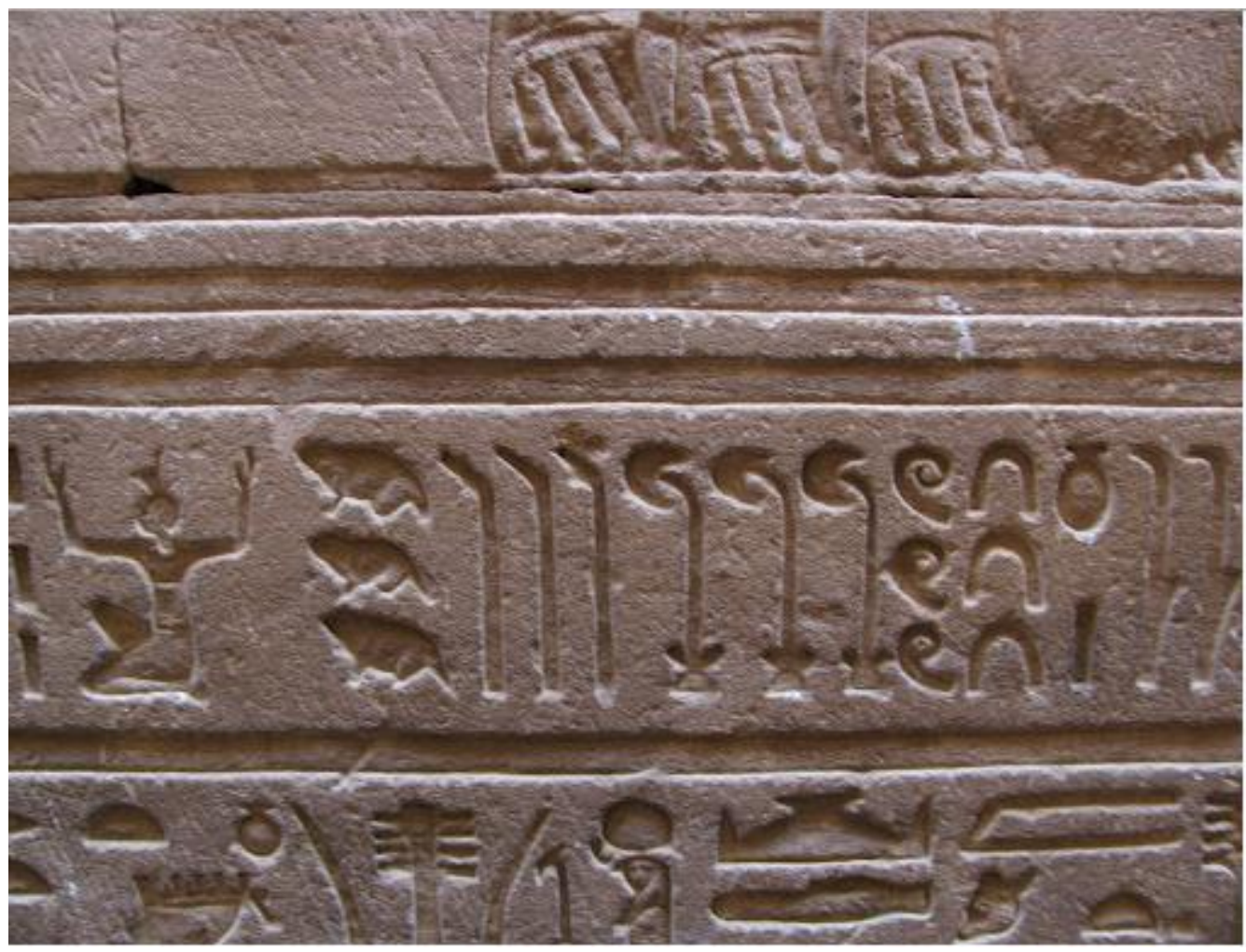

Fonte: BOSE (2016)

Os egípcios tinham a necessidade de medir periodicamente os seus terrenos, uma vez que a cada cheia do rio Nilo, dada a alteração do terreno, poderiam perder ou até mesmo ganhar algum pedaço de terra que não lhe pertencia. Como os egípcios pagavam impostos sobre a terra, seria necessário saber com exatidão as medidas do terreno para calcular o imposto devido (Beck,2015). Nos estudos de Oliveira (2004) ele nos conta que ao avançar sobre as margens, o rio derrubava as cercas de pedra que cada agricultor usava para marcar os limites do seu terreno. Usavam cordas para fazer a medição e nessa corda havia uma unidade de medida. As pessoas encarregadas de medir esticavam a corda e 
verificavam quantas vezes aquela unidade de medida continha os lados do terreno. Desta prática se origina o termo "estiradores de cordas". Acredita-se que devido a medidas que não cabiam uma quantidade inteira de vezes dentro do terreno medido, foi necessária uma outra forma de numeração, o que hoje chamamos de números fracionários.

Considerando então a existência desse novo conceito para os números, que agora deveriam ser não somente inteiros, mas também quebrados e ainda as partes que deveriam ser quebradas poderiam ser também variáveis, ou seja, não necessariamente os egípcios teriam uma situação similar na qual eles pudessem recorrer sempre que fosse necessário. O que de fato foi feito:

Os números fracionários eram representados com símbolos diferentes dos usados para os números inteiros, o que não acontecia no sistema babilônico. Havia dois tipos de fração. As frações comuns eram representadas por símbolos próprios, escrito em hierático e hieróglifo, [...], As outras eram escritas colocando-se um marcador em forma oval (em hieróglifo) em cima do que constituía, hoje, o denominador. Ou seja, eram obtidas escrevendo os números inteiros com uma oval em cima. Por exemplo, 1/7 seria escrito com a oval sobre sete barras verticais: [...] Esse tipo de fração corresponde às que escreveríamos hoje como $1 / \mathrm{n}$, ou seja, frações que diríamos ter "numerador 1". Esse símbolo oval colocado acima do número não possui, porém, o mesmo sentido daquilo que chamamos hoje de "numerador". As frações egípcias não tinham numerador. Nosso numerador indica quantas partes estamos tomando de uma subdivisão em um dado número de partes. Na designação egípcia, o símbolo oval não possui sentido cardinal, mas ordinal. (ROQUE, 2012, p. 74).

Os egípcios então possuíam um sentido ordinal em suas frações, para exemplificar a figura (6) nos mostra como eram as imagens relativas as frações egípcias. 


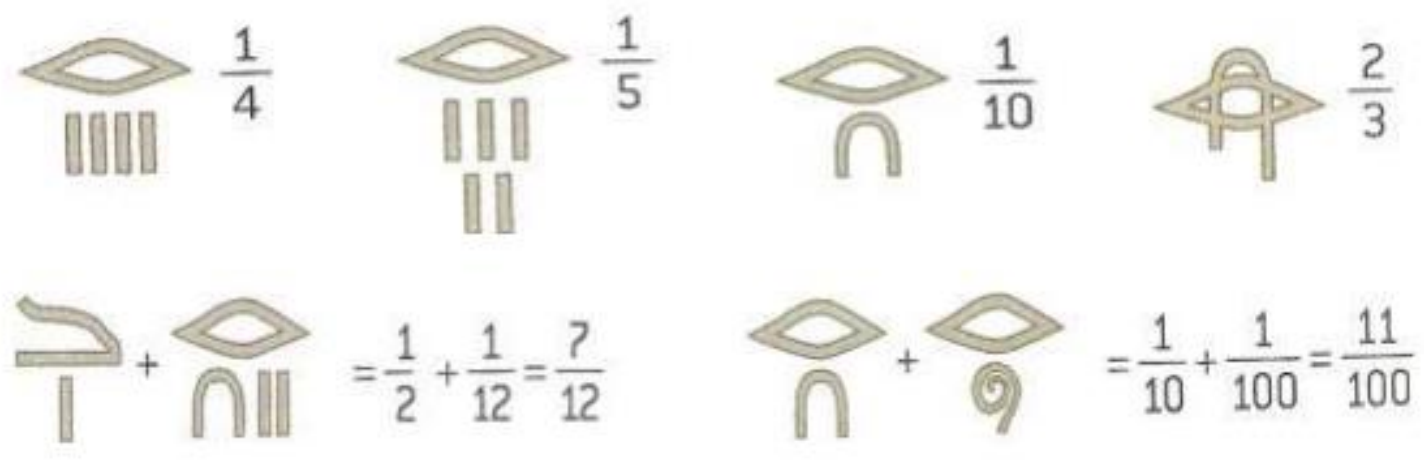

Fonte:RIBEIRO (2010, p. 138)

As imagens da figura 6 nos mostram algumas frações egípcias e seus símbolos que fazem parte de sua construção, e é interessante notar que os egípcios tinham símbolos diferenciados para algumas frações, como por exemplo, dois terços conforme desenho na figura.

Verificamos, assim, que já data de muito tempo a necessidade de medir e contar. Com o aumento das populações e sua organização em grupos maiores e mais complexos, criavam-se novas situações e cenários que demandavam a construção de um sistema para quantificar as coisas do mundo. No próprio papiro de Rhind (Figura 4) temos diversos problemas que tratam dos mais diversos temas matemáticos e em particular do uso de frações.

Os egípcios usavam com frequência as frações unitárias, no entanto existiam algumas frações que eles não precisavam usar denominador unitário, provavelmente por uma questão computacional e prática. Por exemplo, as frações da forma $n /(n+1)$, que seriam os complementos das frações unitárias, uma que é citada em diversos autores de história é a fração $2 / 3$ que não possui o numerador igual a 1 .

Certamente podemos observar uma tendência maior no direcionamento e no ensinamento da matemática nos egípcios. Os problemas que aparecem nos papiros mostram uma preocupação com a continuidade do ensino de matemática para as outras gerações. Não se pode concluir, é claro, que essa fosse de fato a maior preocupação do escriba Ahmes. quando fez a escrita no papiro de Rhind. A continuidade no que diz respeito ao sistema numérico favoreceu muito mais a Babilônia. Pode-se dizer também que graças ao sistema sexagesimal posicional que era utilizado na babilônia. Corrobora essa ideia EVES, que diz que a matemática no Egito antigo nunca alcançou a o nível 
obtido pela matemática babilônica. Esse fato, Eves (2011) afirma que esse fato pode ser consequência do desenvolvimento econômico mais avançado na Babilônia.

Mas pode-se dizer que os egípcios também teriam suas vantagens em sua forma de representar as frações, pois, se tivéssemos, por exemplo, que comparar uma desigualdade de duas, ou mais, frações, precisaríamos primeiramente reduzi-las ao mesmo denominador, ao passo que os egípcios não teriam essa dificuldade pois cada fração seria representada por uma soma de outras frações com numerador igual a 1.

\subsection{Outros sistemas decimais}

Uma das coisas mais relevantes que podemos encontrar em histórias da matemática é o quando as civilizações, mesmo em diferentes locais geográficos, precisavam encontrar uma maneira de quantificar as coisas, buscando assim facilitar vários tipos de relações de administração e comércio. Disse BOYER (2010), "Como Aristóteles observou há muito tempo, o uso hoje difundido do sistema decimal é apenas o resultado do acidente anatômico de que quase todos nós nascemos com dez dedos nas mãos e nos pés".

Ainda complementando a citação Boyer (2010) fala que,

Se o problema da linguagem não fosse tão difícil talvez sistemas rivais do decimal tivessem feito maiores progressos. A base cinco, por exemplo, foi uma das que deixaram a mais antiga evidência escrita palpável; mas quando a linguagem se tornou formalizada, o dez já predominava. (Boyer, 2010 p. 3).

A China, que pode ter sua história dividida de maneira que contemple quatro períodos de maior importância, sendo eles: "China Antiga (c. 2000 - 600 a.C.), China clássica (c. 600 a.C. - 221 d.C.), China Imperial (221 d.C. - 1911) e China Moderna (de 1911 até o presente)" Eves, 2011 p.. 234. Descobriu-se tardiamente que os chineses usavam não somente um sistema de numeração decimal, como também frações decimais para resolver determinados problemas práticos de matemática. De acordo com EVES (2011), "Yanh Hui, cujos livros são uma espécie de extensão dos Nove Capítulos sobre a 
Arte da Matemática, trabalhou habilmente com frações decimais; em essência seu método era o mesmo que se usa hoje".

Uma civilização que marcaria de forma positiva várias notações e utilidades para a matemática é sem dúvida a Árabe. Acredita-se que a civilização árabe surgiu no Oriente Médio, numa península desértica situada entre a Ásia e a África. O conhecimento árabe se deu, muito provavelmente, quando o califa Al-Mansur (714-775 AD), após ter se estabelecido na capital Bagdá, que na época acabou se transformando em um novo centro de estudo de matemática. Outro califa, Al-Rashid (786-809 AD), posteriormente estabeleceu, em Bagdá, a "Casa da Sabedoria” e al-Kashir (1308-1429 AD) de acordo com BOYER, comparável ao antigo Museu de Alexandria. Os califas que fizeram parte desse momento na história árabe buscavam a excelência do conhecimento e nos estudos. (Fonte: Wikipedia, verbetes “Al-Mansur”. “Al-Rashid” e Jamshial Al-Kashi)

Muitos matemáticos árabes e hindus tiveram influência no desenvolvimento da matemática, em particular um matemático e astrônomo que compreendeu e usou números decimais e as frações decimais: o persa Al-Kashi. Boyer (2010) nos diz que "Al-Khashi foi de grande importância para a matemática e astronomia e também para a história das frações decimais, pois “embora até certo ponto tivesse precursores, ele foi talvez, dentre os que usavam frações sexagesimais, o primeiro a sugerir que as decimais são igualmente convenientes para os problemas que exigem muitas casas exatas". Apesar de Al-Kashi ter sugerido o uso de frações decimais no lugar de frações sexagesimais, ele mesmo apresentou diversos trabalhos nos quais usava a notação de fração sexagesimal.

\subsubsection{O fim das frações sexagesimais}

Com o advento dos cálculos astronômicos mais precisos, foi necessário a alteração da base sexagesimal, visto que essa poderia complicar mais do que ajudar os astrônomos de sua época.

Como citado anteriormente o matemático árabe Al-Kashi, contribuiu para a mudança do sistema sexagesimal para o sistema decimal. Na Europa

O desenvolvimento do comércio gerou novas necessidades para a Matemática. Por exemplo, Christoff Rudolff (1499-1545), um polonês que estudou e trabalhou em Viena, na Áustria, é considerado o primeiro a propor 
o uso sistemático de representações decimais na Europa, e o fez pelas necessidades de representação de juros compostos. Também é atribuída a ele a criação do símbolo da raiz quadrada utilizado atualmente. (BROLEZZI; MONTEIRO, 2003, p.23).

Com o aumento dos tipos de tributos da época e com a necessidade de cálculos com mais precisão foi necessário a criação de um sistema que pudesse ser entendido por todos e que fosse de fácil aplicação,

Neste trabalho [Rudolff] havia resolvido um exemplo de juros compostos, e usou a barra precisamente como devemos usar um ponto decimal hoje. Se qualquer indivíduo em particular viesse a ser nomeado como tendo a melhor razão para ser chamado o inventor de frações decimais, Rudolff parece ser o homem, porque ele aparentemente sabia como operar com estas formas, bem como apenas para escrevê-los, como vários antecessores tinham feito. Sua obra, no entanto, não foi apreciada, e, aparentemente, não foi compreendida, e não foi até 1585 que um livro sobre o assunto apareceu. (SMITH, 1925 p. 328. Tradução nossa).

Assim como Rudolf, François Viete (1540 - 1603), sugeriu que se usassem as frações decimais em lugar das frações sexagesimais.

Viete não era matemático por vocação. Na juventude ele estudou e praticou direito, tornando-se membro do parlamento da Bretanha; mais tarde tornou-se conselheiro do rei, servindo primeiro sob Henrique III, depois sob Henrique IV. [...] Só o tempo de lazer de Viete era dedicado a Matemática, no entanto fez contribuições a aritmética, álgebra, trigonometria e geometria. (BOYER, 2010, p. 207).

Em seus estudos Viete, (Boyer, 2010), utilizava as frações decimais no lugar das sexagesimais. Ele disse em uma obra intitulada "Canon-mathematicus", de 1579, que os sexagesimais deveriam ser pouco, ou nunca, usados, e as frações decimais usadas exclusivamente. 
Figura 7 - Fraçois Viéte

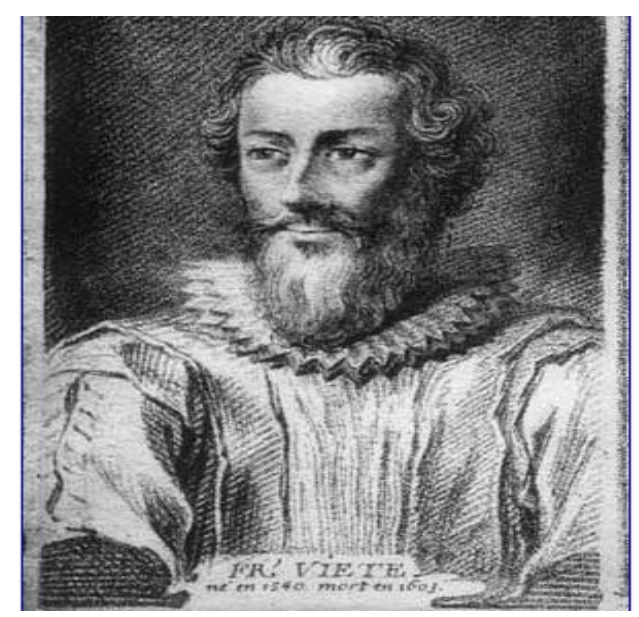

Fonte: FRANÇOIS VIÈTE. In: WIKIPÉDIA.

Crosby (1999, p.. 118) diz que "os europeus foram salvos pelo sistema decimal, que talvez já existisse em forma embrionária desde o início do século XIII, mas que passou mais trezentos anos sem dispor de um sistema de notação útil’. Os europeus não sabiam, mas há muito tempo já se usavam as frações decimais em outras civilizações antigas como a China e a Árabe por exemplo. Um matemático que deu um tratamento quase que final ao tema das frações sexagesimais em decimais foi Simon Stevin (1548 1620), ele buscou uma sistematização para o trabalho com as frações decimais. Eves (2011) o considera o mais destacado e influente matemático dos Países baixos no século XVI. Ainda nas palavras de Eves, Stevin é conhecido principalmente pela contribuição nas antigas teorias das frações decimais. Seu livro que foi publicado em 1545 em Leyden, chama-se De thiende (O décimo na tradução francesa) e que foi traduzido completamente para o francês sob o nome La Disme e publicada no mesmo ano conforme relatos históricos. Sob esse momento Boyer (2010) diz:

Entre o povo em geral, no entanto, e mesmo entre praticantes da matemática, as frações decimais só se tornaram amplamente conhecidas quando Stevin se dispôs a explicar o sistema de modo elementar e completo. Ele queria ensinar a todos "como efetuar, com facilidade nunca vista, todas as computações necessárias entre os homens por meio de inteiros sem frações”. Isto é, 
estranhamente Stevin se concentrava em seus décimos, centésimos e milésimos, etc. (BOYER, 2010, p. 217)

Figura 8 - Simon Stevin

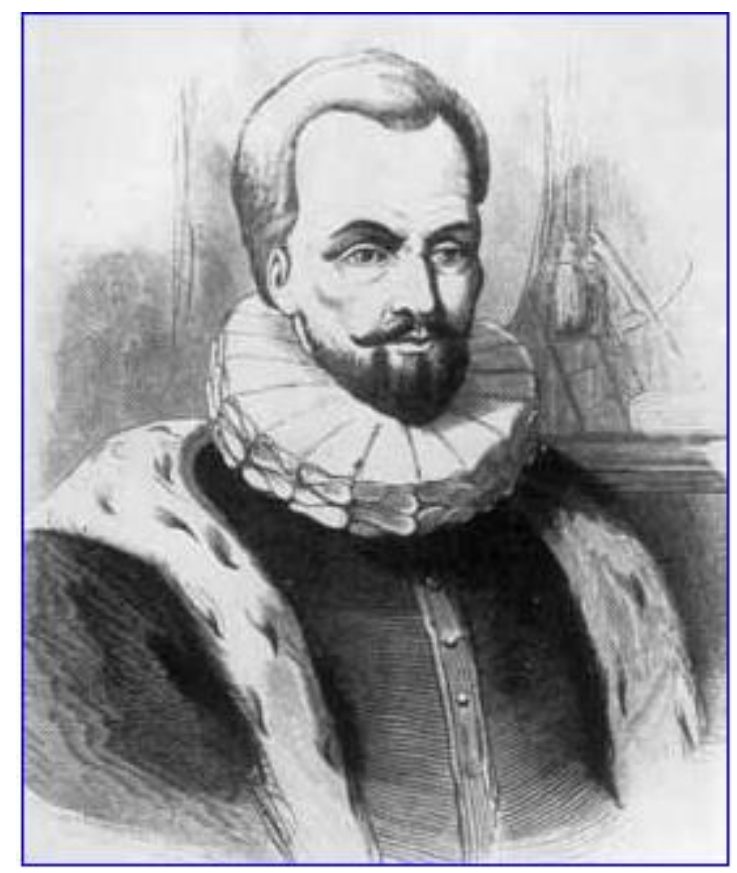

Fonte: WIKIQUOTE (2017)

A maneira com a qual Stevin trabalhava com as expressões decimais não foi a última que se associou aos dias atuais, Stevin usava uma notação que por exemplo para o número 12,351(escrito na notação atual)poderia ser escrito da seguinte maneira.

\section{2(1) 3(1) 5(3)}

Segundo BOYER, Stevin não usava as pavavras "decimais", "centésimos" etc., ele fazia o uso de palavras com mensal a ordinal como por exemplo, "primo", "terceiro" etc., de certa forma bem parecido com a maneiro com a qual eram designadas as frações sexagesimais. A notação que usamos hoje em alguns países não demorou muito a aparecer depois dos esforços de Stevin, John Napier ( 1550 - 1617) um proprietário escocês que também era conhecido como Barão de Murchiston, apesar de não ser um matemático profissional teve grandes contribuições para a matemática, e entre elas publicou um livro intitulado de "Descriptio" que já mostra as frações decimais como as conhecemos hoje em alguns países, com um ponto separando a parte inteira da parte fracionária. É interessante também mencionarmos que vários matemáticos da época 
tratavam os números que estavam em forma fracionária como se fossem números quebrados, talvez desse ponto tenha surgido a ideia de falar que os números que não estavam em forma de fração fossem chamados de inteiros. Corrobora essa ideia Barthelélemy, que em seu livro "2500 Anos de Matemática” escreve o seguinte:

\begin{abstract}
A utilização das frações, entendendo-se por isso a nossa disposição de dois números um por baixo do outro, cedo foi adotada. Quando se começou a atuar sobre as frações, pareceu que os verdadeiros números e frações admitiam ser misturados. [...], desse modo acabámos por falar das frações como de números, qualificando-as com frequência como quebradas. Foi por se adquirir o hábito de considerar os números quebrados que, por contraste, se começou a falar em números inteiros.” (BARTHELÉLEMY, 1999, p. 51)
\end{abstract}

Para a matemática que se desenvolve nos dias atuais, devemos muito aos que trabalharam duramente para transformar os sistemas e as notações de maneira que quando precisássemos trabalhar com elas tivéssemos maior facilidade, devemos certamente aos árabes o uso da barra para separar o numerador e o denominador de uma fração e a Stevin a difusão das frações decimais no período pós renascimento.

\title{
2.6 As frações e os decimais no século XXI
}

Com o intuito de apresentar o uso das frações e dos decimais no século XXI, mostraremos a seguir algumas imagens para a discussão do seu uso e de sua permanência. 


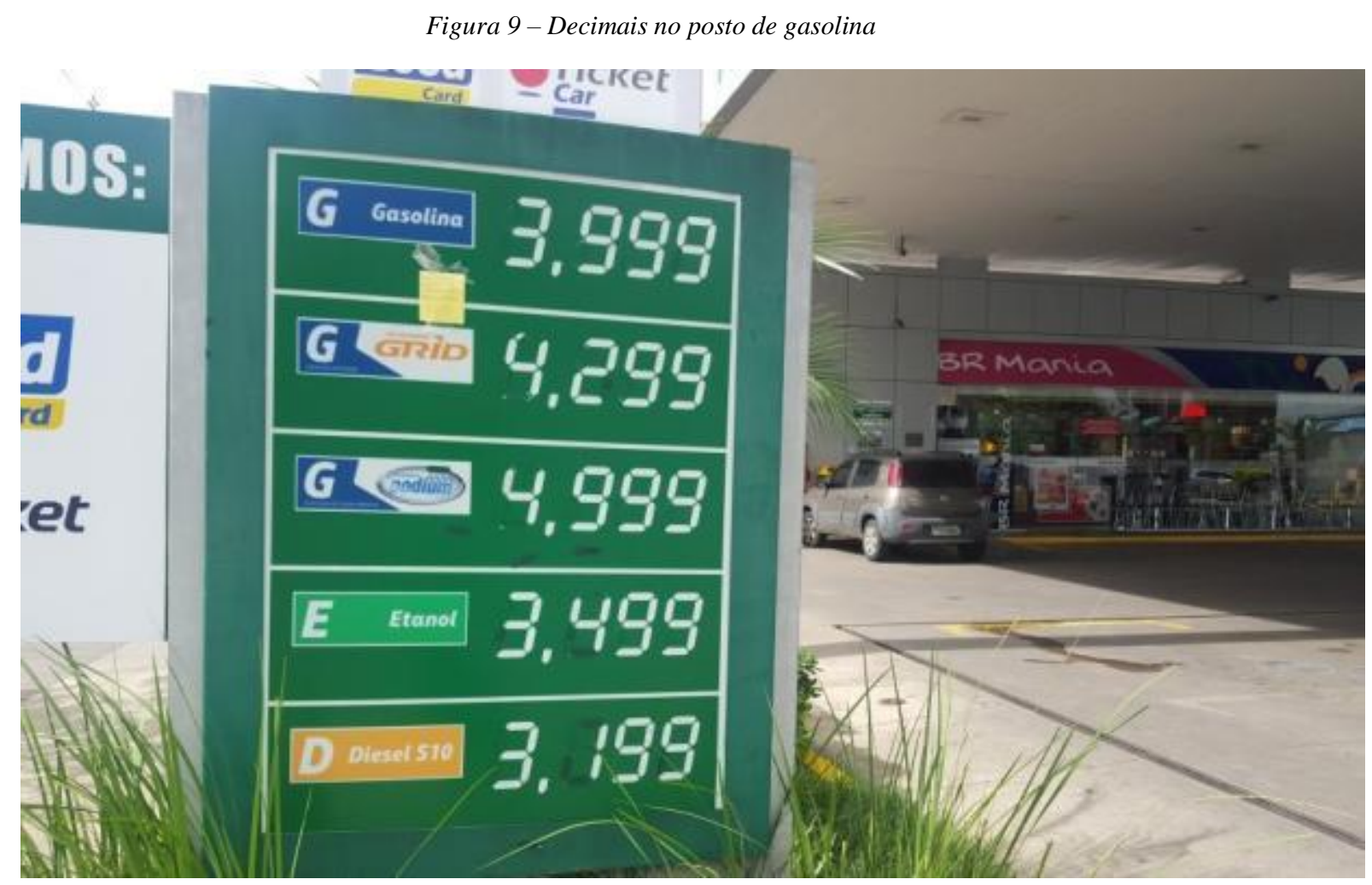

Fonte: FORTUNA (2016)

Na figura (9), observamos o uso dos numeros racionais em forma decimal, incluindo-se até a terceira casa depois da vírgula, ou seja, três casas decimais para fazer a cobrança dos produtos do posto de gasolina.

Existem diversas regras que são estabelecidas pelo governo e por agentes financeiros para a utilização das casas decimais em determinados investimentos, empréstimos, parcelamentos, doação etc. Como, exemplo, coloco a seguir algumas imagens que tratam de regras para uso das casas decimais.

Com o efeito do uso de números racionais em forma decimal acabamos precisando de truncamentos para determinadas situações. A ideia de truncamento é definida "cortando-se" todas as casas decimais a partir de uma casa decimal dada sem qualquer critério estabelecido. Já quando falamos em arredondamento temos um critério que o define que geralmente é usado como segue: 
Figura 10 - Arredondamento ABNT

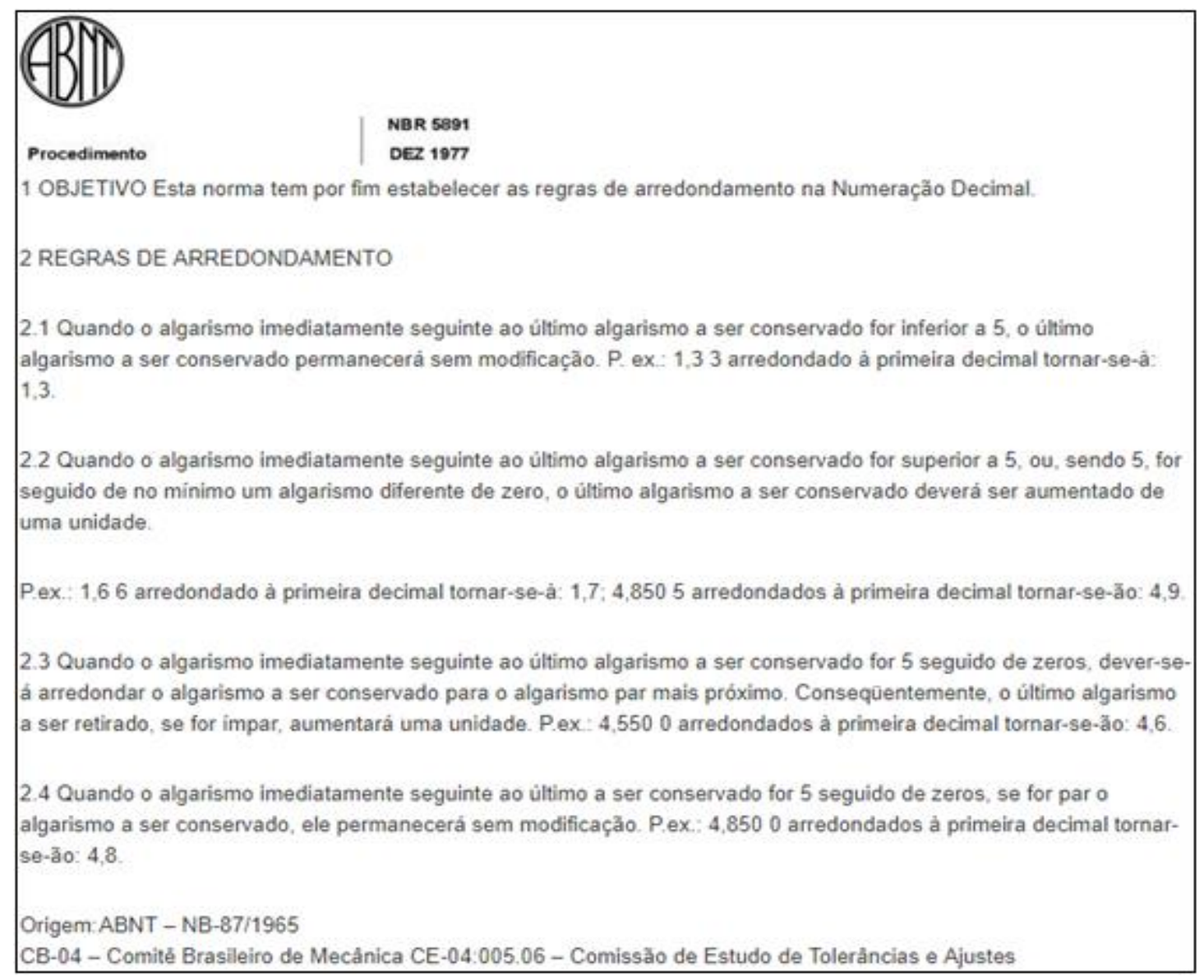

Fonte: $A B N T$ (1977)

Na figura 10 vemos as definições da ABNT para arredondamentos nos cálculos com números decimais, esses calculos de arredondamento fazem parte de um padrão definido de forma a manter-se uma forma de diminuir as diferenças de medidas em diferentes situações. Outro exemplo do uso de números racionais em forma decimal determinado por um padrão á o da taxa PTAX.

A PTAX é a média da taxa de câmbio do dólar norte-americano, calculada diariamente pelo Banco Central do Brasil, com base no movimento diário da moeda. É a média ponderada apurada sobre os volumes negociados no decorrer do dia. Entretanto, com a publicação da Circular Bacen no 3.506/2010, passou a ser calculada como média aritmética tomando por base quatro consultas realizadas em momentos distintos do dia, sempre ouvidas todas as instituições credenciadas como dealer. (LUZ, R. 2012. P. 122). 
Um exemplo do cálculo da taxa PTAX pode ser visualizado na imagem abaixo com uma aplicação.

Figura 11 - Cálculo de PTAX

- Por exemplo: Num determinado dia, é fechado um negócio entre duas instituições no valor de 10 milhões a cotação de 1,90. Logo depois, é fechado um outro negócio de 20 milhões com dólar cotado a $\mathbf{R} \$ \mathbf{2 , 0 0}$. O PTAX é a média ponderada dos dois negócios, Acompanhe o cálculo:

Ptax $=\underline{(\text { US } \$ 10 \text { milhões } \times 1,90)+(\text { US } \$ 20 \text { milhões } \times 2,00)}=1,96$ 10 milhões +20 milhões

- O Bacen divulga PTAX parciais, em intervalos de meia hora, e depois, divulga o PTAX do dia.

Fonte: CAMISA (2014)

Na figura (11) o calculo da taxa PTAX termina com um resultado na forma decimal utilizando-se duas casas decimais. Na figura (12) mostraremos as ideias de truncamento aplicadas pelo calculo de Notas do Tesouro Nacional (NTB). 


\section{Notas do Tesouro Nacional-NTN-B}

- Cálculo da cotação

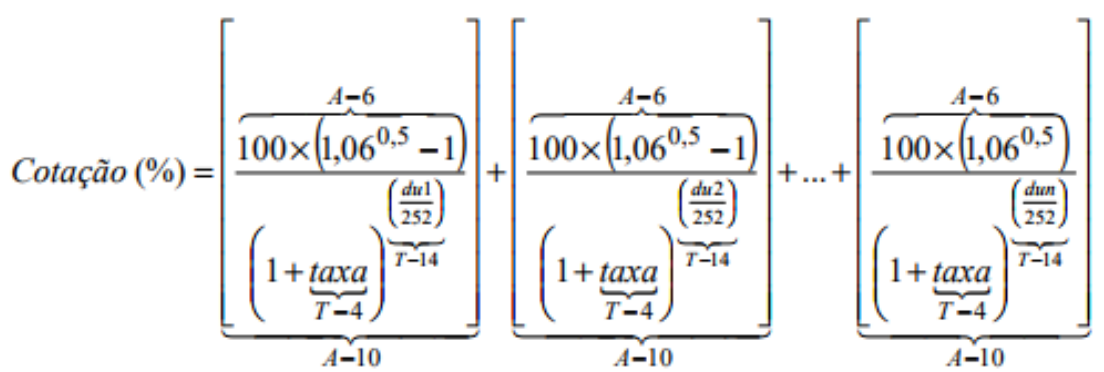

Onde:

taxa $=$ taxa interna de retorno (Padrão du/252 \% a.a. $=>$ truncar na $4^{\mathrm{a}}$ casa decimal); $\mathrm{du}=$ número de dias úteis entre a data de liquidação (inclusive) e a data de vencimento (exclusive).

Fonte: FAZENDA (2002)

Em um detalhe separado por uma linha poligonal vermelha na figura (12) consta o escrito "truncar na $4^{\text {a }}$ casa decimal", ou seja, após o calculo das Notas do Tesouro Nacional toma-se por padrão o truncamento do número decimal.

A sociedade moderna está completamente acostumada com o uso de números racionais em forma decimal, é raro encontrar pessoas que façam o uso de números racionais em forma de fração nos dias de hoje. Como exemplo podemos observar a imagem abaixo de uma receita de um bolo de chocolate. 
Figura 13 - Receita de bolo de chocolate

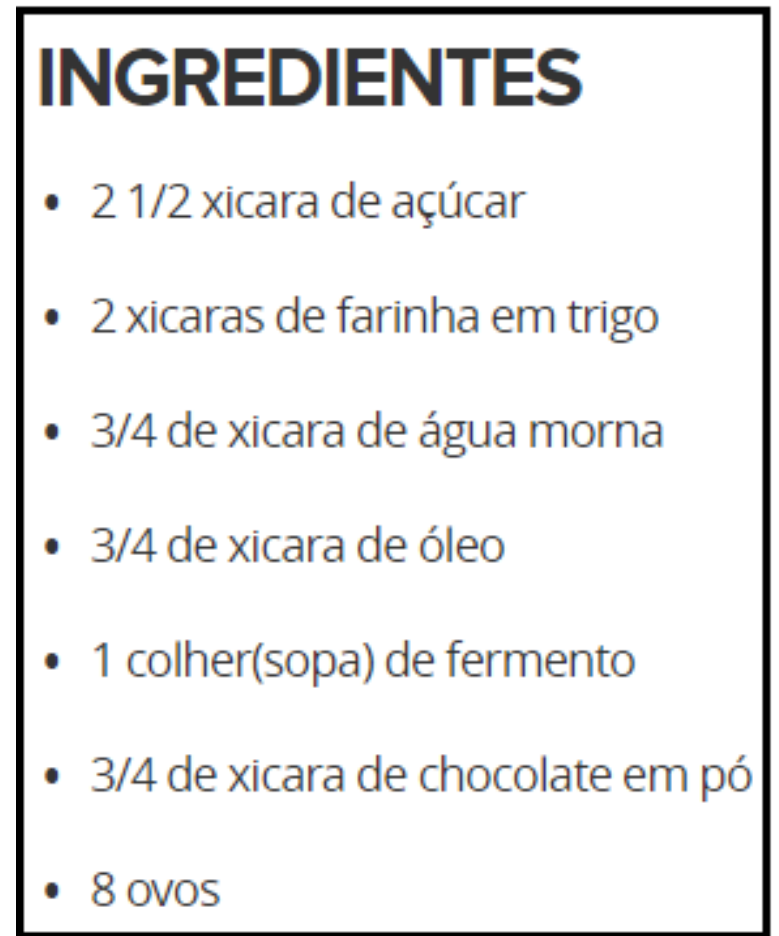

Fonte - VICTORIA (2012)

Podemos observar nessa imagem que o cozinheiro, ou confeiteiro, utilizou medidas envolvendo ideias de números naturais e números racionais em forma de fração. Em uma leitura teríamos o seguinte: duas xícaras de açúcar e meia de açúcar, duas xícaras de farinha de trigo, três quartos de xícara de água morna, três quartos de xícara de óleo, uma colher de sopa de fermento, três quartos de xícara de chocolate em pó e oito ovos.

Acerca do uso dos números racionais em forma de fração em nosso cotidiano, temos uma quantidade menor de aparições em comparação com o uso dos números racionais em forma decimal.

Buscamos neste capitulo mostrar o quanto a história das frações é importante e cheia de riquezas que podem fazer parte do conhecimento de nossos alunos. 


\section{CONCEITOS E FUNDAMENTOS}

\subsection{Considerações iniciais}

Neste capitulo discutiremos os principais conceitos relacionados à ideia de frações sob a luz de alguns autores e pesquisadores que já se debruçaram sobre essa temática. Ressaltamos também algumas possíveis dificuldades na compreensão do conceito de fração, e alguns tratamentos utilizados por pesquisadores em situações semelhantes a desse estudo.

\subsection{Caracterização das frações}

As diferentes concepções de fração fazem parte de uma gama de discussões que começaram há muito tempo. KIEREN (1975) alertou a comunidade cientifica para o fato de os números racionais assumirem diferentes significados dependendo do contexto em questão. Para ele, aprender sobre os números racionais dependeria do seu entendimento sobre suas diferentes interpretações. Os significados básicos para a compreensão dos números racionais de acordo com Kieren seriam: quociente, parte-todo, medida, razão e operador. Não muito tempo depois os pesquisadores POST, BEHR e LESH (1982) mostraram que a forma para que se construa as ideias relacionadas aos números racionais dependeriam de uma série de subconstructos distintos, que em outras palavras seriam eles quociente, parte-todo, medida, razão e operador, fazendo assim uma convergência entre esses pesquisadores e Kieren. Ainda seguindo uma determinada ordem, NUNES (1997) nos mostra sete possíveis significados dependendo das situações sendo eles: medida, razão, taxa, quociente, coordenadas lineares, decimal e operador. Druck (1994) aponta noções semelhantes já partindo-se de uma notação porque segundo ela pode significar uma fração, divisão, razão ou um número racional. Algum tempo depois, e acredita-se talvez que inspirada nos trabalhos de Kieren, NUNES (2003) afirma que para que exista de fato uma aprendizagem nos conceitos pertinentes a fração é necessário explorarmos cinco significados: parte-todo, medida, quociente, operador multiplicativo e número, 
sendo que cada um desses devem ser trabalhados com uma gama diferente de situações ou representações.

Um documento que aponta na mesma direção dos diferentes significados das frações é o chamado de BNCC (Base Nacional Comum Curricular) que foi homologada no dia 20-12-2017 pelo ministro da educação Mendonça Filho.

Segundo a Base Nacional Comum Curricular (BNCC), p.. 426, precisamos no $7^{\circ}$ ano escolar ensinar aos alunos as ideias relacionadas a: compreender, comparar e ordenar frações associadas às ideias de partes de inteiros, de resultado da divisão, razão e operador, identificando frações equivalentes. Ainda na BNCC "Frações: significados (parte/todo, quociente), equivalência, comparação, adição e subtração; cálculo de fração de um número natural; adição e subtração de frações." (BNCC,2017, p. 298).

Antes da homologação da BNCC, tínhamos os PCN (Parâmetros Curriculares Nacionais) e algumas ideias do que está escrito no PCN corrobora o que se espera do ensino das frações no BNCC. Sobre o PCN:

O processo de elaboração dos PCN começou em 1995, sendo que no fim daquele ano já havia a versão preliminar, que foi apresentada a diferentes instituições e especialistas. Em resposta, o MEC recebeu cerca de 700 pareceres, que foram catalogados por áreas temáticas e embasaram a revisão do texto. Para completar, Delegacias do MEC promoveram reuniões com suas equipes técnicas, o Conselho Federal de Educação organizou debates regionais e algumas universidades se mobilizaram. Tudo isso subsidiou a produção da versão final dos PCN para $1^{\mathrm{a}}$ a $4^{\mathrm{a}}$ série, que foi aprovada pelo Conselho Federal de Educação em 1997. Os PCNs foram transformados num conjunto de dez livros, cujo lançamento ocorreu em 15 de outubro de 1997, Dia do Professor, em Brasília. Depois, professores de todo país passaram a recebê-los em casa. Enquanto isso, o MEC iniciou a elaboração dos PCN para $5^{\text {a a }} 8^{\text {a }}$ série." (Roque 2012 p.1). 
Veremos na figura 14 detalhes sobre a página 55 dos PCN e seus diferentes significados de frações.

Figura 14 - Exploração dos significados de fração - PCN

- Formulação de hipóteses sobre a grandeza numérica, pela observação da posição dos algarismos na representação decimal de um número racional.

- Extensão das regras do sistema de numeração decimal para compreensão, leitura e representação dos números racionais na forma decimal.

- Comparação e ordenação de números racionais na forma decimal.

- Localização na reta numérica, de números racionais na forma decimal.

- Leitura, escrita, comparação e ordenação de representações fracionárias de uso fre-qüente.

- Reconhecimento de que os números racionais admitem diferentes (infinitas) representações na forma fracionária.

- Identificação e produção de frações equivalentes, pela observação de representações gráficas e de regularidades nas escritas numéricas.

- Exploração dos diferentes significados das frações em situaçōes-problema: partetodo, quociente e razão.

- Observação de que os números naturais podem ser expressos na forma fracionária.

- Relação entre representações fracionária e decimal de um mesmo número racional.

- Reconhecimento do uso da porcentagem no contexto diário.

Fonte: Parâmetros Curriculares Nacionais, 2008, p. 55

Sobre os conceitos das frações e suas possíveis definições mostraremos algumas formas de interpretação dos mesmos em um aspecto que mostre uma possível gênese histórica de númeos fracionários, a qual foi utilizada no trabalho de tese de doutorado de SILVA (2005). Para explicar os diferentes significados das frações, SILVA se propôs a analisar historicamente as situações que poderiam levar a criação de tais significados e 
elaborou um esquema que pudesse explicar a gênese desses significados. Abaixo a figura 8 nos mostra o esquema elaborado por SILVA (2005).

Figura 15 - Esquema de gênese histórica dos números fracionários.

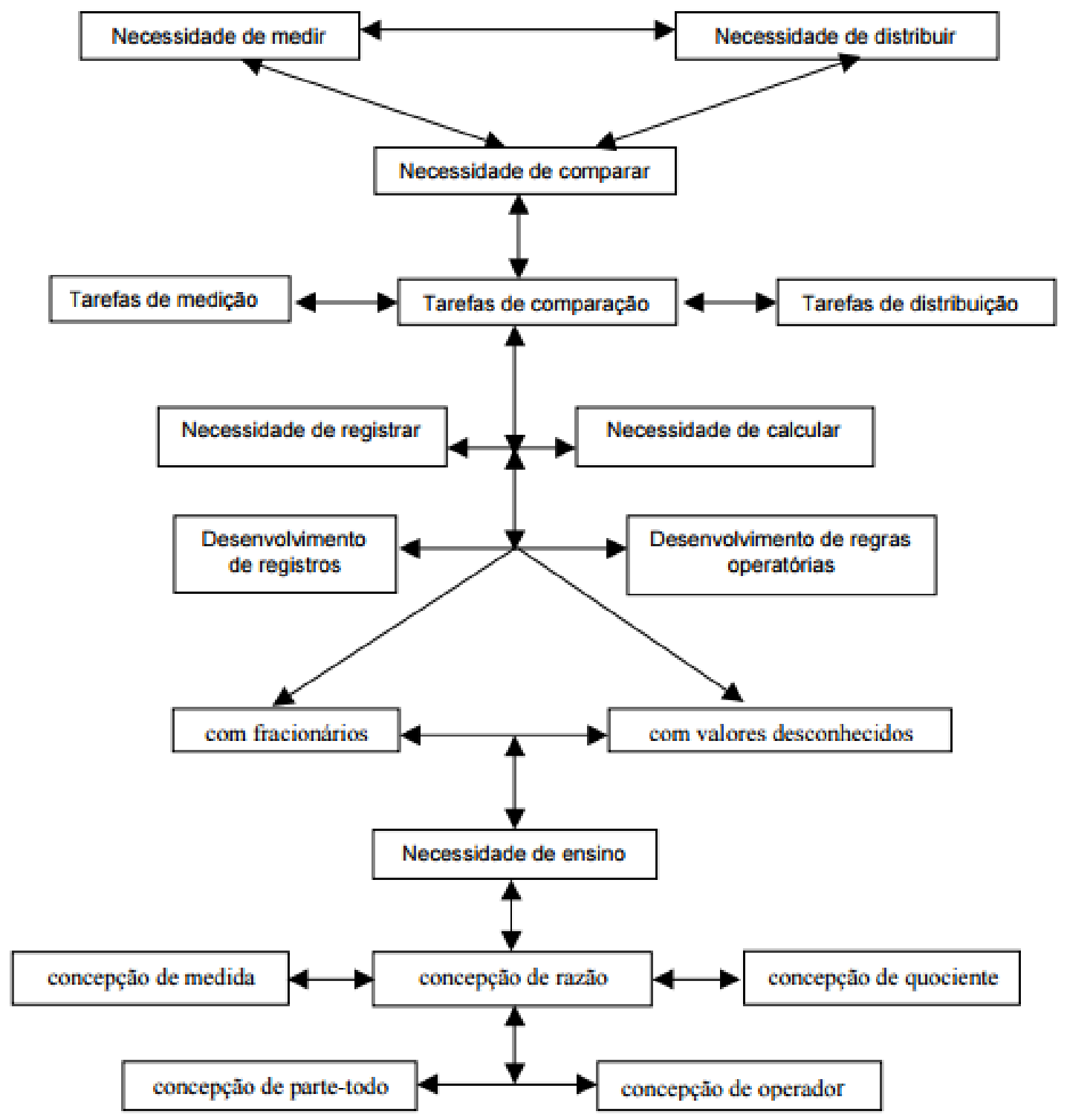

Fonte: Retirado de SILVA (2005) p.. 88

A figura (15) apresenta as ideias da gênese histórica de números fracionários desenvolvida por Silva (2005). No esquema acredita-se que a necessidade de medir, necessidade de distribuir, necessidade de comparar, tarefas de medição, tarefas de 
comparação, tarefas de distribuição, necessidade de registrar, necessidade de calcular, desenvolvimento de registros, desenvolvimento de regras operatórias, com fracionários, com valores desconhecidos, necessidade de ensino, concepção de medida, concepção de razão, concepção de quociente, concepção de parte-todo e concepção de operador, façam parte da construção das frações com relação a suas necessidade e seus períodos históricos relacionados. Nas palavras de Silva (2005)

Embora o esquema dê a impressão de linearidade dos fatos ou de ordem cronológica, isso não é verdade, [...], as necessidades de medir, distribuir e comparar quanto a de buscar as técnicas para cumprir essas tarefas apresentaram-se simultaneamente na Antiguidade. Como consequência imediata, a necessidade de registro de tais técnicas e de cálculos com os novos números encaminham a necessidade do ensino do conhecimento envolvido. Esse ensino, por sua vez, verifica-se por meio de tarefas que enfatizam o cálculo com fracionário e a descoberta de valores desconhecidos e associam as concepções medida, quociente e razão para fracionários que se relacionam entre si e com as concepções parte-todo e operador. (Silva, 2005 p. 88-89).

Façamos agora uma breve análise de cada caso dos possíveis significados de frações, conforme foram definidos nos estudos de Silva (2005), sendo eles: parte-todo, medida, quociente e operador multiplicativo.

\subsubsection{Parte - Todo}

Para entendermos de uma forma básica esse significado, pensemos na partição de um todo em $\mathbf{n}$ partes iguais, cada parte podendo ser representada por $1 / \mathrm{n}$, em seguida, escolhemos $\mathbf{m}$ partes para assim ficarmos com $\mathrm{m} / \mathrm{n}$ partes de um todo.

Esse significado é muito utilizado no ensino de fração no Brasil, principalmente nos anos iniciais, e resume-se a dividir a área em partes iguais, a nomear a fração como o número de partes pintadas sobre o número total de partes e analisar a equivalência e a ordem da fração por meio da percepção. Tais ações podem levar os alunos a desenvolverem seus raciocínios sobre 
fração baseados apenas na percepção em detrimento das relações lógicomatemáticas (Nunes e Bryant, 1997; Nunes et al.,2005).

Poderíamos pensar que somente essa classificação básica para a relação parte-todo de significado das frações fosse o suficiente para aprofundar-nos nessa temática, mas na verdade quando se trata de parte-todo devemos nos ater a outros importantes detalhes. $\mathrm{O}$ que nas palavras de SILVA (2005), “A concepção parte-todo emerge da ação de dividir uma grandeza contínua (comprimento, área, volume, ...) em partes equivalentes ou uma grandeza discreta (coleção de objetos) em partes iguais em quantidades de objetos." Exemplos:

Figura 16 - Fração 7/9

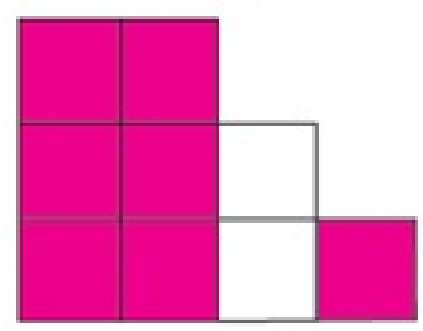

Fonte: Autor
Figura 17 - Fração 1/2

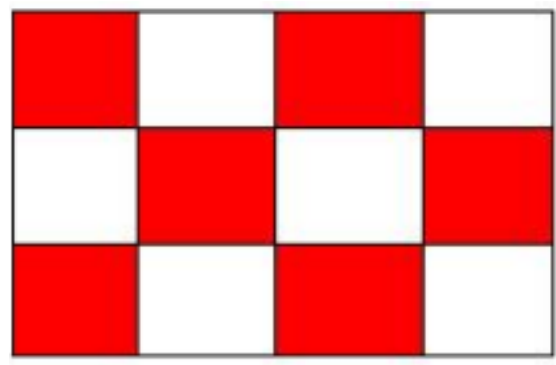

Fonte: Autor

\subsubsection{Medida}

Segundo SILVA (2005), as ideias que envolvem direta ou indiretamente as medições de comprimento, são apropriadas para a percepção da limitação que os números naturais possuem e também da necessidade de encontrar números que possam quantificar determinados comprimentos que a priori não poderiam ser quantificados de maneira inteira.

As tarefas de medição naturalmente associam a concepção de medida, solicitando a manipulação de um padrão, chamado de unidade de medição que, por sua vez, dependerá diretamente da grandeza em jogo. Entendemos que medimos grandezas contínuas e contamos grandezas discretas, embora possamos citar a moeda instituída por uma sociedade como uma unidade que mede suas transações de compra e venda, como no caso de grandeza discreta. 
O poder de compra do cidadão de um certo país é medido por uma unidade monetária que pode ser comparada com a de outros países: um dólar compra mais que um real, por exemplo. No entanto, embora as unidades monetárias sejam divididas em cem partes: os centavos. (Silva F. J. M.,2005 p.. 117).

Para melhor exemplificar seu ponto de vista, SILVA (2005) separa em quatro os tipos de medida e os coloca da seguinte ordem: $1^{\circ}$ Determinar medidas de comprimento de um objeto, $2^{\circ}$ Determinar medidas em segmentos divididos em partes iguais, $3^{\circ}$ Determinar medidas em segmentos não divididos em partes de mesma medida e por último o $4^{\circ}$ Reconstituição da unidade. Como exemplo mostro abaixo uma imagem retirada de SILVA (2005) página 121.

Figura 18 - Problema envolvendo a noção de medida

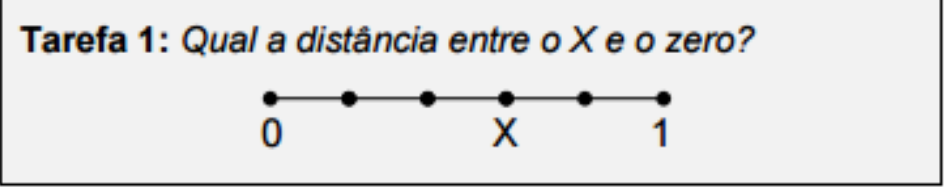

Fonte: Retirado de SILVA (2005), p. 119

\subsubsection{Quociente}

De acordo com CERVANTES (2010), a ideia que representa esse significado de frações está presente em situações que envolvam a ideia de divisão, por exemplo, se precisássemos repartir uma pizza de maneira igual entre cinco crianças. Ela ainda nos afirma que nas situações em que usamos o significado de quocientes devemos levar em consideração duas variáveis, como por exemplo, número de pizzas e número de crianças, sendo que uma dessas variáveis corresponderá ao numerador e a outra dessas variáveis ao denominador, no caso mencionado no início teríamos a representação $1 / 5$, ou seja, cada criança deverá receber $1 / 5$. 
SILVA (2005) no que diz respeito ao uso de situações quocientes nos leva à seguinte reflexão. Se tivéssemos que distribuir igualmente três barras de chocolates entre cinco crianças, quanto de chocolate receberia cada criança? Para essa resposta ela diz que mantendo o aspecto partitivo da divisão, neste caso, teríamos que cada criança receberia 3/5 de um chocolate ou três pedaços de 1/5 de chocolate. Ainda segundo SILVA (2005), poderia no caso dos chocolates mencionado, ocorrer uma fuga para os naturais, se considerarmos que $15 \div 5=3$. É preciso, segundo ela, notar a diferença entre, dividir um inteiro ou unidade em cinco partes iguais e, destas, considerar três partes, da situação de dividir três inteiros em cinco partes iguais, embora os dois casos possam ser representados como na figura 11, retirada de SILVA (2005), p.. 123.

Figura 19 - Concepção de quociente, problema dos chocolates e das crianças.

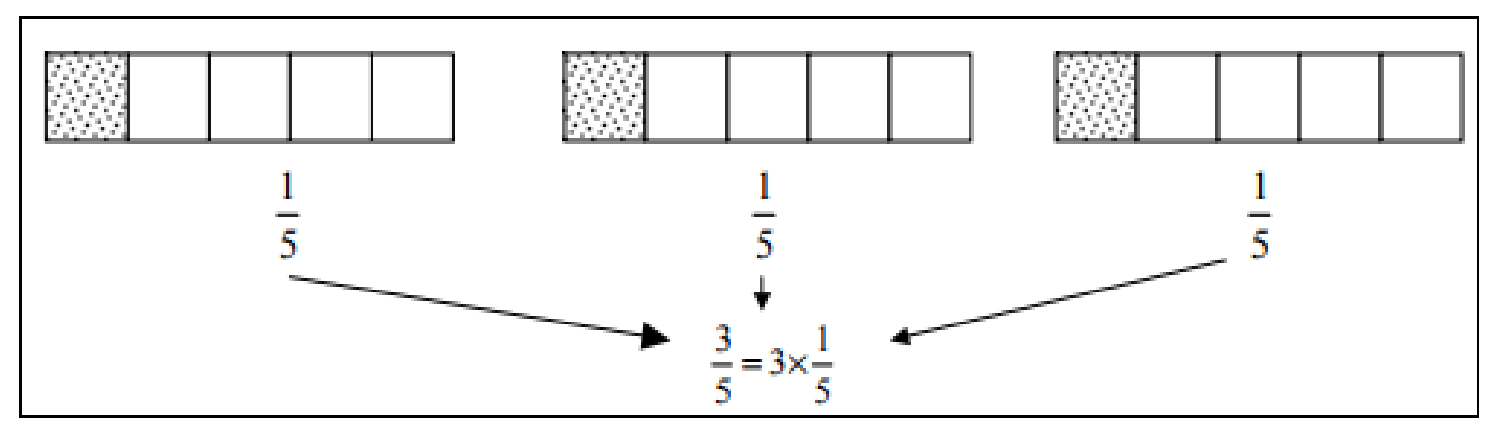

Fonte: Retirado de Silva (2005), p. 123

\subsubsection{Razão}

A concepção de razão nos significados das frações é apresentada por SILVA (2005, p.125-126) da seguinte maneira “As tarefas associadas à concepção de razão, para números fracionários, geralmente, não permitem associar a ideia de partição como nas anteriores, mas a ideia de comparação entre medidas de duas grandezas. Nesse sentido, a apresentação $a / b$ ou a:b, utilizada para esses casos, nem sempre se associa à concepção de quociente, seria entendida como um índice comparativo, sem necessariamente transmitir a ideia de número. Assim, a representação fracionária 2/3, por exemplo, associada à concepção de razão, não permitiria a leitura "dois terços" e, sim, "dois para três". O entendimento da razão como "x para y" encaminharia, naturalmente, para a 
equivalência de razões e para o raciocínio proporcional que, por sua vez, solicita uma representação: $a / b=b / c$. A proporcionalidade envolve diretamente a equivalência de números fracionários e caracteriza-se, como uma ferramenta poderosa para a resolução de problemas. Na descrição inicial da situação, uma constante é apresentada, implícita ou explicitamente, determinada por uma relação particular entre a e b, em que qualquer mudança em a provocará uma mudança previsível em b. As tarefas que associam a concepção de razão podem comparar grandezas de mesma natureza ou não, em contextos contínuos e ou discretos, podendo ainda estar associadas a situações do tipo: todo-todo quando compara as quantidades de dois inteiros; parte-parte - quando compara as quantidades de duas partes de um inteiro ou partes de dois inteiros, ou ainda, parte-todo."

Figura 20 - Uso de razões em problemas com fração

Tarefa 8: Determine a razão entre a quantidade de figuras de coração do conjunto $A$ e a quantidade de figuras de lua do conjunto $B$.

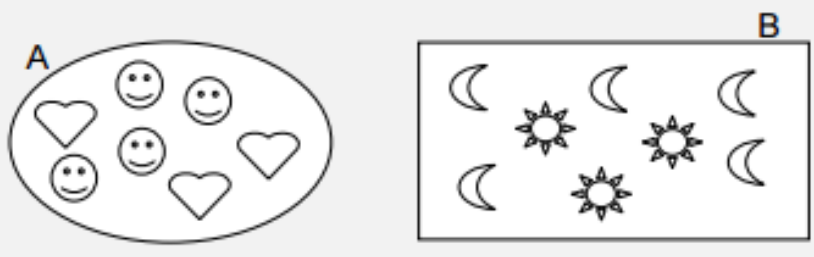

Tarefa 9: Determine a razão entre a quantidade de bolinhas pintadas e a quantidade de bolinhas brancas da figura abaixo:

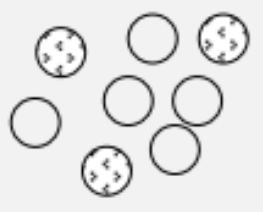

Fonte: Retirado de Silva (2005, p. 128).

\subsubsection{Operador}

SOUZA (2004, p.. 6) "Esse significado está associado o papel de transformação, isto é, uma ação que se deve imprimir sobre um número, transformando o seu valor nesse processo. Exemplo: Pedro tinha uma coleção de 30 soldadinhos de chumbo e deu a seu amigo 2/3 dessa coleção. Com quantos soldadinhos de chumbo Pedro ficou? ". Corrobora essas ideias SILVA (2005, p.. 134), "Nas tarefas que solicitam a mobilização da 
concepção de operador o fracionário a/b é manipulado como "algo que atua sobre uma quantidade" e a modifica produzindo uma nova quantidade". Essa ação pode ser entendida pela ação de operador fracionário que modifica o estado inicial e produz um estado final.

Seriam ainda ideias que poderiam exemplificar o estudo do caso de operador, por exemplo, buscando o referencial em SILVA (2005), construir um quadrado cujo lado tenha $2 / 3$ da medida do lado do outro quadrado dado, ou ainda, se a capacidade de $3 / 5$ de um recipiente é de 36 litros, qual a capacidade do recipiente? Ainda na mesma linha poderíamos analisar, quantos alunos correspondem a 2/3 de uma classe com 36 alunos?.

Figura 21 - Problema com concepção de operador

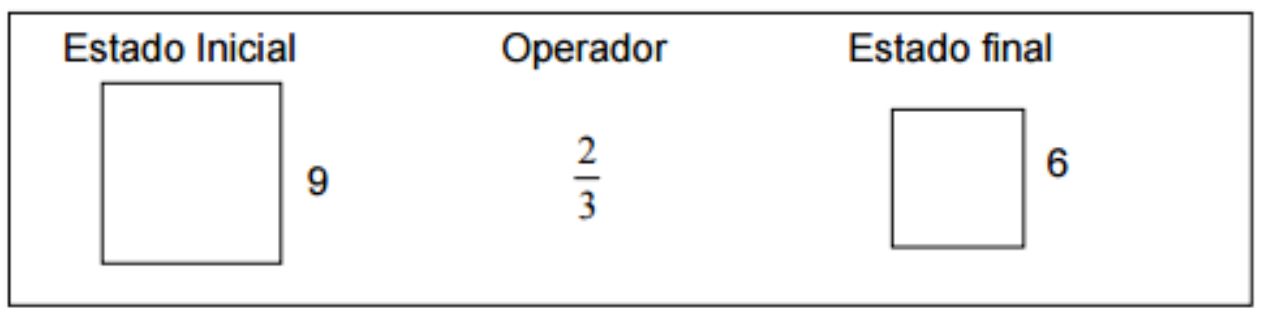

Fonte: Retirado de Silva (2005, p.. 138)

Dadas essas caracterizações e especificidades das frações, observamos uma riqueza de detalhes que podem ser analisadas de uma forma a permitir um maior desenvolvimento no que diz respeito ao aluno que poderia aproveitar todo esse conhecimento e usá-lo de forma simples e conceitual em seu cotidiano.

\section{METODOLOGIA}

Mostraremos neste capitulo nossa abordagem metodológica para a formação do trabalho, elaborada à luz do conjunto teórico apresentado. 


\subsection{Participantes}

Participaram quarenta e cinco estudantes, meninos e meninas, que atualmente são alunos do sexto ano de uma escola privada do estado de São Paulo, cidade de Barueri. Escolhemos as turmas do sexto ano por entender que sendo eles alunos da fase inicial do segundo ciclo do ensino fundamental, ou fundamental II, ainda não tiveram contato significativo com o conteúdo de frações; desta maneira, poderemos apresentar este conceito de forma a ajudá-los a compreender de maneira mais significativa os conhecimentos acerca das frações, facilitando assim seus posteriores anos no último ciclo do ensino fundamental.

No ambiente escolar, os grupos são separados em dois sextos anos (a saber, T6A e T6B). O sexto ano A compreende alunos brasileiros e estrangeiros de ambos os sexos (treze meninos e doze meninas) que tem em média onze anos de idade. O sexto ano B é um grupo formado por treze meninos e sete meninas com a mesma média de idade do grupo A, 11 anos. Uma diferença entre as turmas é o fato de haverem mais alunos estrangeiros no sexto ano B do que no sexto ano A.

É uma escola bilíngue cuja missão é

"Proporcionar aos nossos estudantes uma sólida formação acadêmica, um conhecimento global e a oportunidade de tornarem-se autônomos e capazes de interagir com todas as culturas. E cultivar em nossos alunos:

O respeito às diferenças;

A importância de contribuir com a sociedade e com o meio ambiente;

O espírito de liderança e o empreendedorismo;

Atitudes éticas baseadas em sólidos princípios e valores morais;

A busca de uma excelente qualidade de vida;

A sensibilização em relação a trabalhos comunitários;"

Fonte: site

https://www.escolainternacional.com.br/bra/idx_acontece_int.php?noticias\&id=103

\section{2 - Planejamento}

Buscando ideias novas para desenvolver o ensino de frações e estudando a teoria das situações didáticas propostas por Brousseau (1986), encontramos fundamentos para 
propor uma sequência didática dos conceitos de fração em sala de aula, a qual poderá ser uma ferramenta para o ensino e aprendizagem dos conceitos de fração. Seguimos estudando a Teoria das Situações de Brousseau para elaborar uma sequência didática que levasse em conta as etapas de ação, formulação, validação e institucionalização de modo que pudéssemos utilizar no contexto escolar e analisar os resultados da aplicação dessa sequência com foco nos referenciais teóricos que foram tratados anteriormente.

\section{3 - Sequência didática}

As sequências didáticas podem ser definidas como um conjunto de atividades ordenadas, estruturadas e articuladas para a realização de certos objetivos educacionais, que têm um princípio e um fim conhecidos tanto pelos professores como pelos alunos (ZABALA, 1998, p.18). Corrobora essa ideia Luiz Carlos Pais, que é professor da universidade federal do mato grosso do sul, e diz que as sequências didáticas também podem ser vistas como "certo número de aulas planejadas e analisadas previamente com a finalidade de observar as situações de aprendizagem, envolvendo os conceitos previstos na pesquisa didática" (PAIS, 2012)..

Para elaboração desta sequência didática, levamos em consideração exercícios que pudessem favorecer a compreensão dos conceitos de fração através da Teoria das Situações Didáticas. Nessa sequência temos problemas que envolvem os diferentes conceitos de frações, elaborados a partir dos estudos de Silva (2005), a saber: parte-todo, razão, medida, quociente e operador. Para cada conceito foi criada uma questão envolvendo a ideia central do problema em uma narrativa atraente que objetiva motivar os alunos à leitura e resolução, conforme motivado por Poligicchio ao defender que

A Matemática, como os demais componentes curriculares, está engendrada numa trama que permite tecer narrativas fabulosas sobre: sua origem, seu desenvolvimento no decorrer dos tempos e com as diversas civilizações, o processo de desenvolvimento de um algoritmo ou de uma demonstração, a construção de determinada tabela ou gráfico, inferências estatísticas, o poder de convencimento e argumentação lógica, o funcionamento de invenções cientificas, o movimento dos astros e os cálculos astronômicos, os números da música...E não faltam temas curiosos e instigantes para nos reportar ao falar de um conteúdo matemático" (POLIGICCHIO, 2011, p. 35). 
A ideia de narrativa, conforme mencionada por POLIGICCHIO (2011), nos indica um caminho para a preparação dessa sequência didática, utilizando enredos que possam contemplar momentos históricos que de outra forma não seriam ensinados aos alunos na escola básica, pois não fazem parte do currículo formal (BNCC, Base Nacional Comum Curricular). Complementarmente, Machado afirma que "a construção do significado, em qualquer assunto, sempre se dá por meio de uma narrativa bem arquitetada: um bom professor, especialmente um bom professor de matemática, é sempre um bom contador de histórias" (MACHADO, 2012, p.18).

Sendo assim construiremos as questões de nossa sequência didática de tal forma que possamos usar uma narrativa que motive os alunos a descobrirem a solução das questões propostas.

Para a aplicação da sequência didática utilizaremos cinco aulas de 45 minutos cada, focando em desenvolver em cada aula uma questão diferente que trate de um conceito diferente de frações a cada aula. $\mathrm{Na}$ aula 1 desenvolveremos a ideia do conceito parte-todo através de uma questão com uma narrativa conforme o anexo X, para aula dois buscaremos evidenciar o conceito de medida, na aula três faremos o conceito de razão, na aula quatro o conceito de quociente e por último na aula cinco o conceito de operador, conforme a tabela 1 abaixo.

Tabela 1 - Relação das aulas

\begin{tabular}{|c|c|c|}
\hline AULA & CONCEITO & TEMPO \\
\hline AULA 1 & Parte-todo & 45 minutos \\
\hline AULA 2 & Medida & 45 minutos \\
\hline AULA 3 & Razão & 45 minutos \\
\hline AULA 4 & Quociente & 45 minutos \\
\hline AULA 5 & Operador & 45 minutos \\
\hline
\end{tabular}

\subsection{1 - Questões da sequência didática}


Para desenvolvermos a sequência didática fizemos a escolha de 10 questões que pudessem colocar o aluno frente a uma situação que envolvesse os conceitos de fração conforme o estudo de Silva (2005). As dez questões fazem parte de uma narrativa em que um Arqueólogo que gostaria de conhecer o Egito, em particular a pirâmide de Quéops, precisa solucionar para dar proseguimento em suas descobertas. Faremos uma breve análise das questões e suas justificativas.

Questão 1 (Filipe Raphael Mattos é personagem fictício?)

Figura 22 - Questão 1

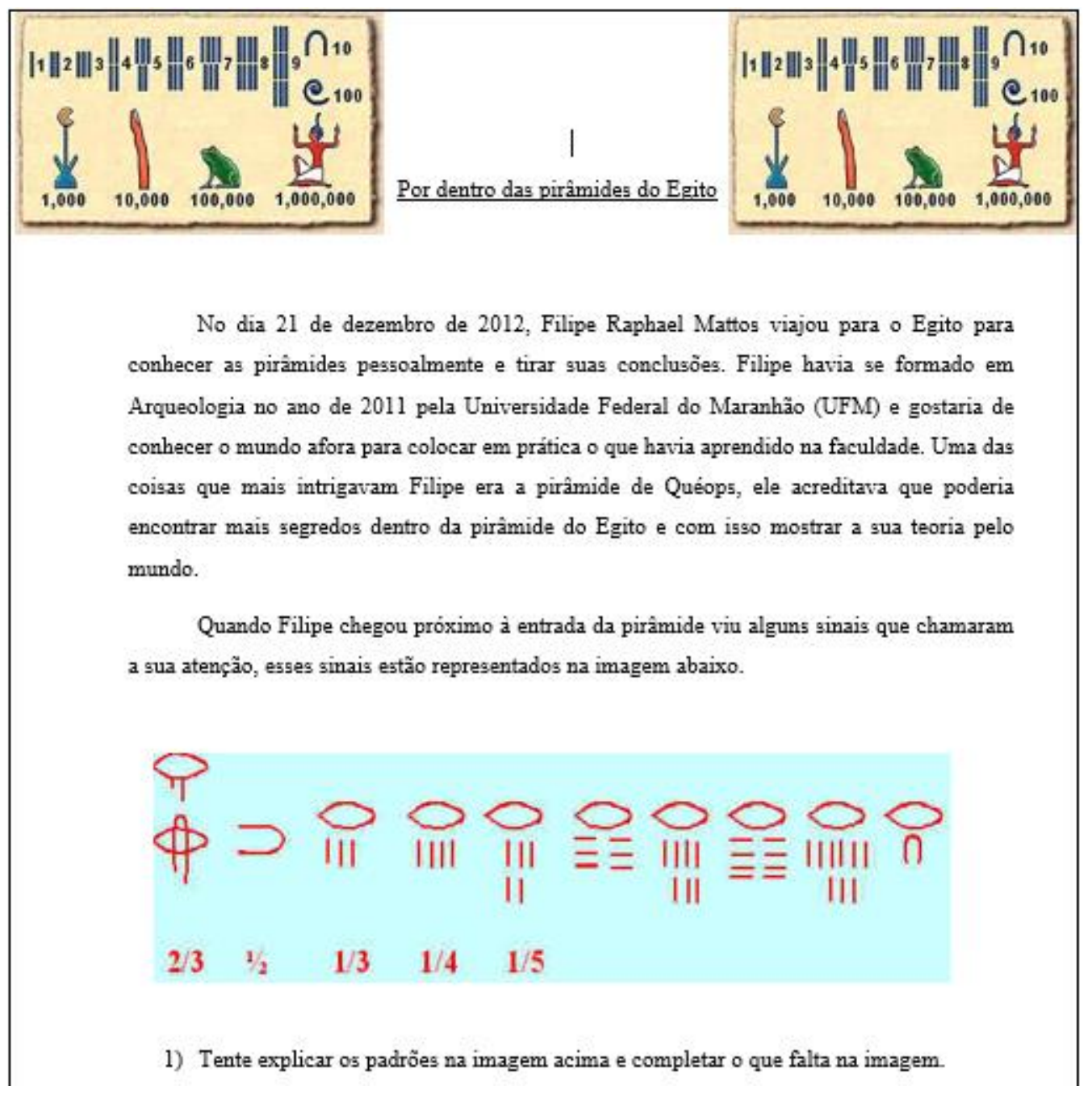

Fonte: Autor

Na questão 1, gostaríamos que os alunos conseguissem determinar, pelo menos em parte, os padrões que formam as frações egípcias. Para isso colocamos na parte de 
cima da questão duas figuras que formavam alguns numerais egípcios, com isso os alunos poderiam verificar os numerais e colocá-los em ordem conforme a questão solicitou. Essa questão deverá fazer com que os alunos possam ter algum contato com a ideia de frações durante uma parte do período histórico, em particular no Egito antigo.

\section{Questão 2}

Para o desenvolvimento da questão 2, levamos em consideração as ideias de parte-todo sugeridas por Silva (2005) e uma questão que pudesse ser usada na narrativa com a sequência didática. A questão sugerida por Silva, foi colocada em outro contexto conforme vemos a seguir.

Figura 23 - Questão parte-todo Silva (2005)

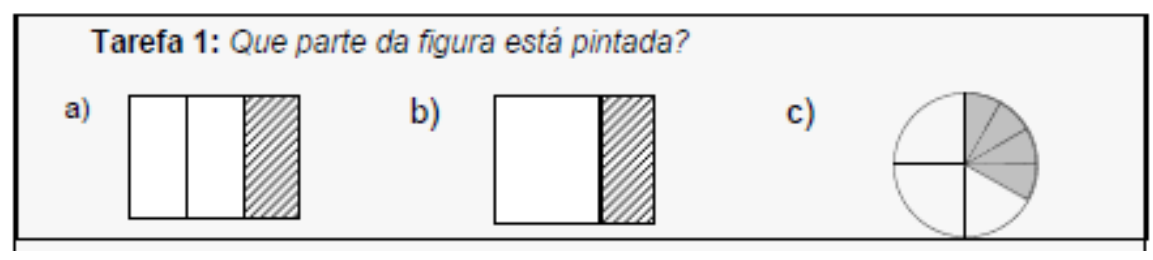

Fonte: Retirado de Silva (2005, p.108)

$\mathrm{Na}$ figura (26) os alunos precisam determinar as partes pintadas e relacionar o número fracionário que corresponde a cada imagem. Fizemos uma adaptação na imagem de Silva (2005) e colocamos como segue na figura (27).

Figura 24 - Questão 2

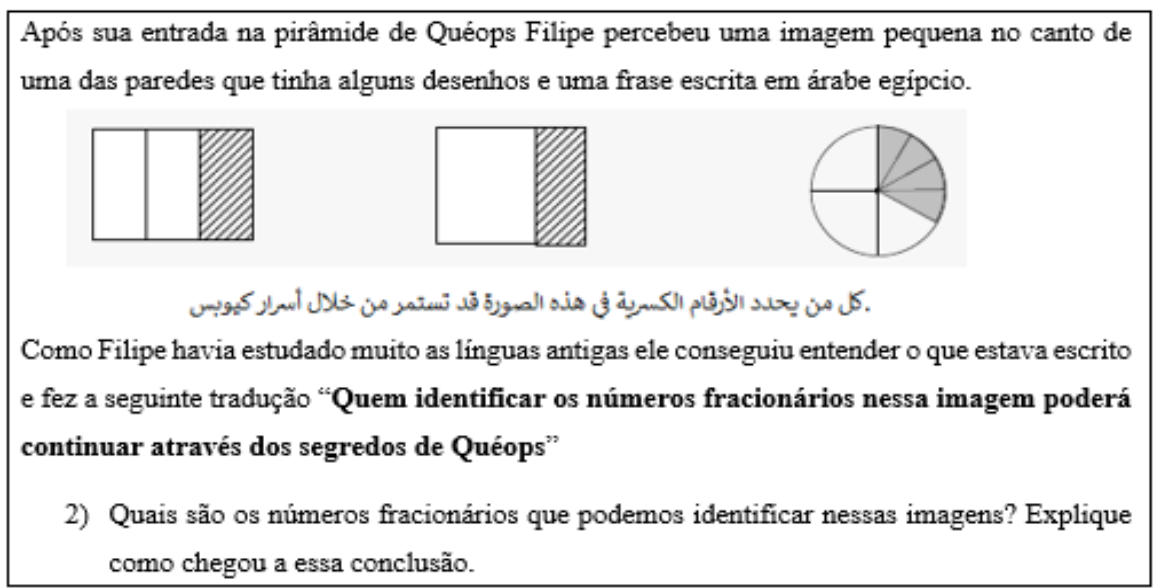

Fonte: Adaptado de SILVA (2005, p. 108). 
Os alunos deveriam encontrar os números fracionários que representavam cada imagem na figura (27) e explicar qual o raciocínio utilizado para a sua resolução. A primeira imagem poderá ser resolvida pelo aluno usando a ideia de dupla contagem das partes, ou seja, basta que ele conte o total de partes que o inteiro foi dividido e as partes pintadas. Para resolver a segunda imagem a ideia é que o aluno consiga identificar que falta um "traço", ou um segmento, que diviria o retãngulo em três partes iguais, fazendo com que ele perceba o número fracionário $\frac{1}{3}$. Na ultima imagem o aluno precisa perceber que a figura não está dividida em partes iguais, é necessário encontrar uma equivalencia entre partes pintatas e não pintadas para que ele consiga fazer a dupla contagem. (SILVA, 2005, p.109).

Complementando as formas de resolução e o pensamento da concepção partetodo, Silva (2005) nos diz que

\begin{abstract}
Nessas tarefas dois conhecimentos são indispensáveis: a natureza do inteiro e como ele pode ser dividido, e o que será considerado como parte desse inteiro. Disso dependerá a construção e ou escolha da técnica adequada para a percepção, inclusive, dos limites da dupla contagem das partes. (SILVA, 2005, P. 108).
\end{abstract}

Então nessa linha de raciocínio bastará aos alunos a compreensão das técnicas de dupla contagem para a resolução dos exercícios de parte-todo.

\title{
Questão 3
}

Para o desenvolvimento da questão 3, utilizamos uma ideia de parte-todo sugerida por Silva (2005), como a reconstituição do inteiro, conforme figura (28).

Figura 25 - Questão parte-todo proposta por Silva (2005).

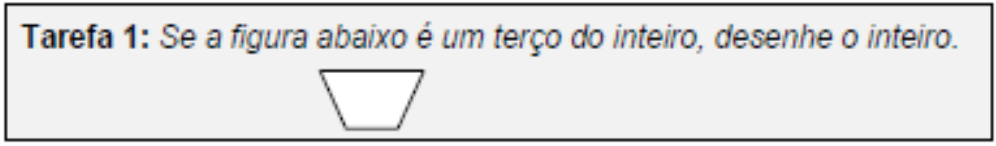

Fonte: Retirado de Silva (2005, p.116). 
Utilizamos a imagem da figura (28) realizando algumas adaptações que possilitasse a tentativa pelos alunos da resolução do problema.

Figura 26 - Questão 3

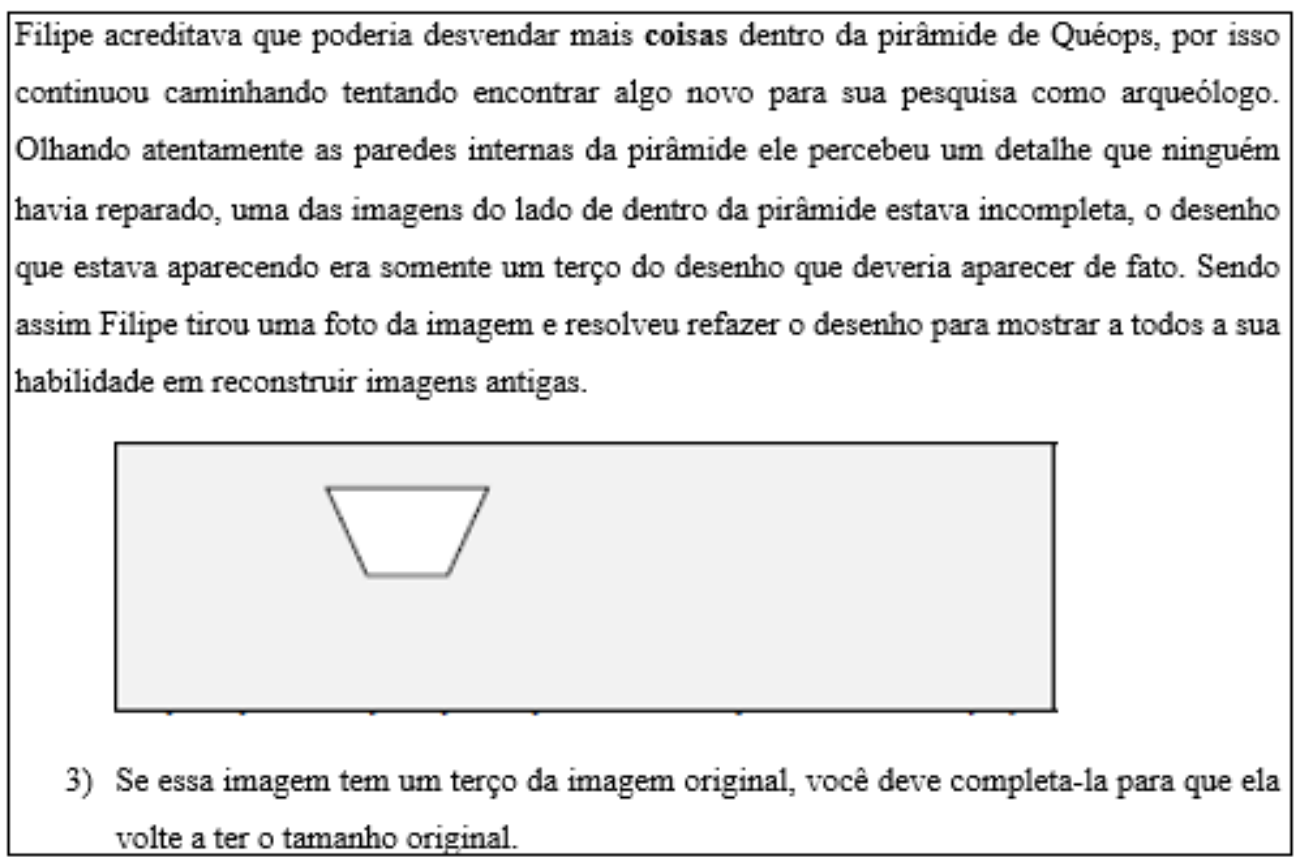

Fonte: Adaptado de SILVA (2005, p. 116).

Após a leitura os alunos deveriam fazer a reconstituição do inteiro, formando assim a figura original. Com relação a como os alunos poderiam resolver o problema Silva (2005) diz

Este tipo de tarefa permitirá a mobilização da reversibilidade da dupla contagem das partes, isto é, se para obter um terço de uma figura, fizermos a divisão em três partes de mesma área, então, quando apenas uma dessas partes for apresentada será necessário percorrer o caminho de volta, obter uma figura com três partes congruentes à figura dada para alcançar o inteiro. Além de auxiliar na percepção visual das figuras e seu tratamento com base na composição, aprofunda a compreensão da concepção parte-todo (SILVA, 2005, p. 116).

Seguindo esse problema os alunos deverão ser capazes de reconstruir a figura dada utilizando qualquer construção que possa remetê-la ao tamanho original, que no caso da questão mencionada será adicionar os dois terços faltantes para completar os três terços 
e assim completar a figura conforme diz o enunciado da questão, fazendo a menção a quantidade de partes em que o todo foi dividido. Essas questões mencionadas anteriormente diziam respeito ao conceito de parte-todo, utilizaremos nos próximos exercícios outros conceitos de fração.

\section{Questão 4}

Para o desenvolvimento da questão 4, utilizamos as ideias de concepção de medida defendida por Silva (2005), em particular a ideia de "determinar em segmentos divididos em partes iguais" que mostraremos na figura 30 a seguir.

Figura 27 - Questão de medida proposta por Silva (2005)

Determinar medidas em segmentos divididos em partes iguais.

Tarefa 1: Qual a distância entre o X e o zero?

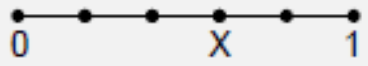

Fonte: Retirado de Silva (2005, p.119).

A principal ideia é que o aluno seja capaz de identificar a medida do zero até o ponto $\mathrm{X}$, para isso o aluno poderá utilizar diversas estratégias diferentes, como uma dupla contagem das partes, considerando que a unidade foi dividida em cinco partes, e que da origem até o ponto X existem três dessas partes. (SILVA, 2005). O que fizemos então foi adaptar a questão quatro para que fizesse parte da narrativa das questões em andamento na sequência didática conforme a figura 31 . 


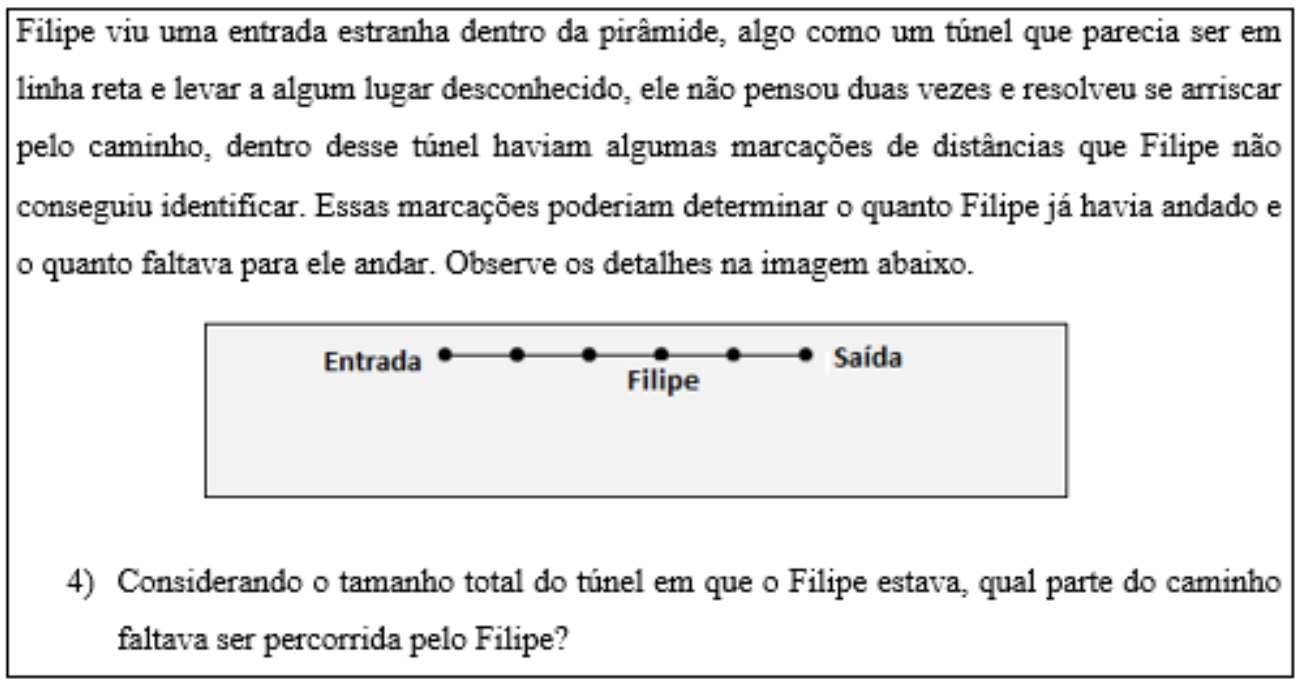

Fonte: Adaptado de Silva (2005, p. 119)

A questão de medida colocada foi adaptada dos estudos de Silva (2005). Continuaremos analisando a questão 5 agora.

\section{Questões 5 e 6}

A questão 5 foi utilizada de acordo com os estudos de Silva (2005), com relação à concepção de medida e a reconstituição da unidade, conforme imagem abaixo.

Figura 29 - Questão de medida - reconstituição da unidade (SILVA,2005)

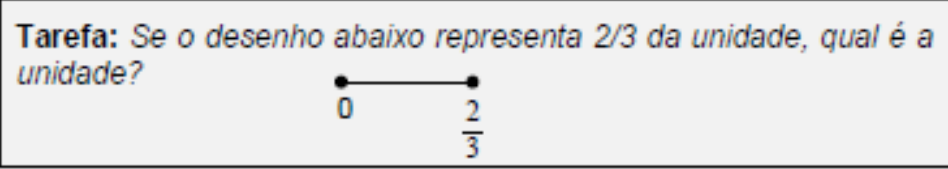

Fonte: Adaptado de Silva (2005, p. 120)

A ideia principal é que o aluno seja capaz de compreender que o segmento representa dois terços, ou seja, o tamanho original da imagem foi dividido em três partes de comprimento igual, sendo que, destas, somente duas são mostradas na imagem. (SILVA, 2005). Fizemos uma adaptação da questão original colocando uma narrativa e outras imagens participando da questão conforme figura (33) abaixo. 
Figura 30 - Questões 5 e 6

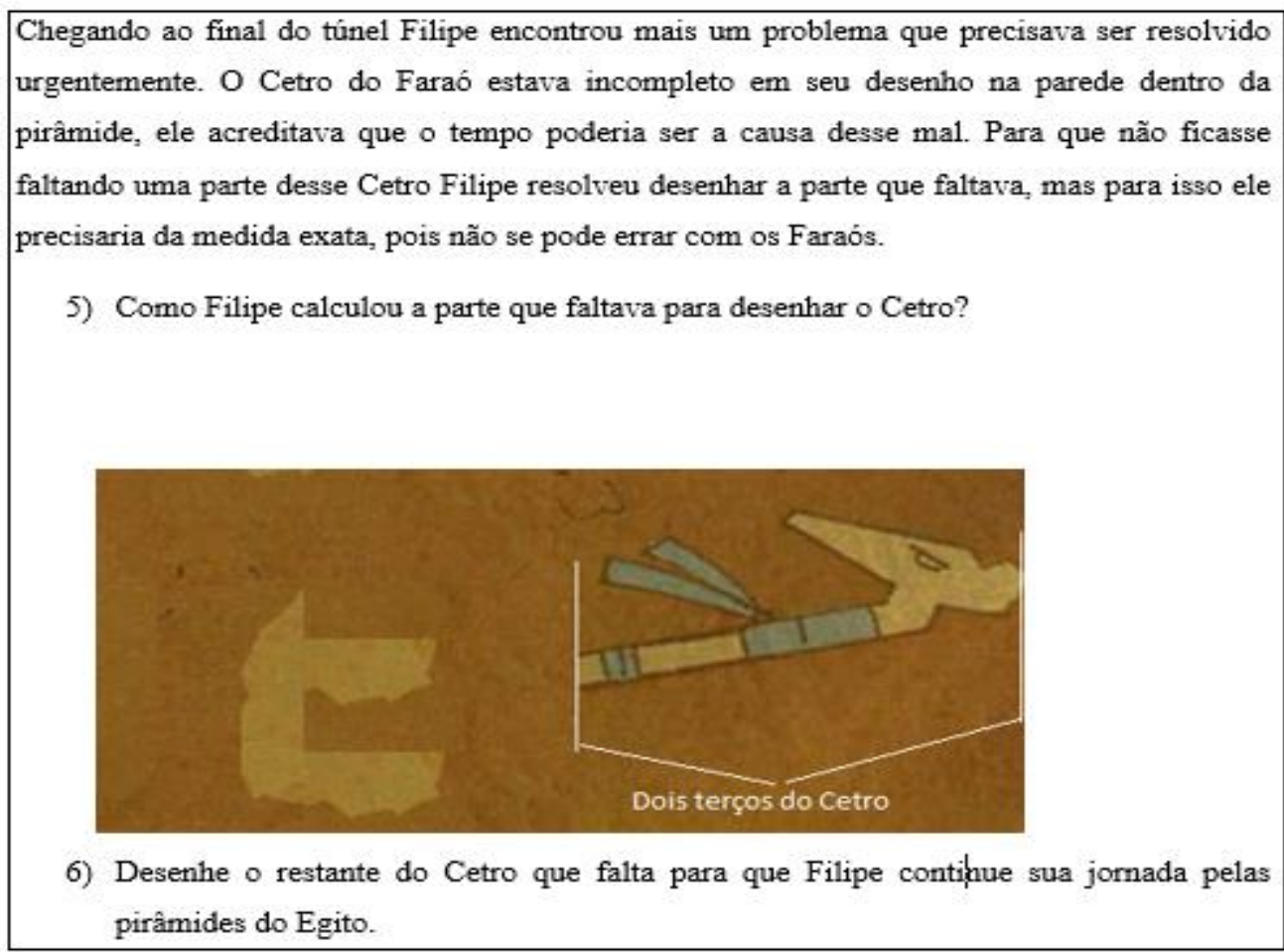

Fonte: Adaptado de Silva (2005, p. 121)

Os alunos deveriam pensar em uma forma de calcular a parte que faltava do "Cetro" e depois desenhar a parte que faltava para completar a imagem inteira, fazendo assim a reconstituição da figura em seu tamanho original.

\section{Questões 7 e 8}

Com o intuito de trabalharmos as concepções de quociente na sequência didática, utilizamos algumas questões propostas pelos estudos de Silva (2005), com a ideia principal de "distribuir igualmente x objetos em um número y de partes". Mostraremos nas imagens que seguem a pergunta original e na sequência a questão adaptada para a narrativa.

Figura 31 - Questão de concepção de quociente proposta por Silva (2005)

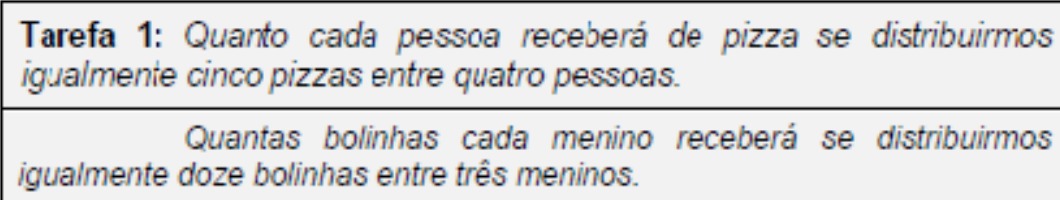

Fonte: Retirado de Silva (2005, p. 122,123) 
Os problemas que aparecem na figura (34), foram readaptados para seguirem dentro da narrativa da sequência didática, o uso desses problemas e suas resoluções são discutidos por Silva (2005) no seguinte.

Este problema refere-se à divisão de grandezas contínuas, em seu aspecto partitivo, cuja quantidade a ser distribuída, igualmente, é maior que o número de partes. Nesse caso, identificamos, pelo menos, duas técnicas, para cumprir a tarefa, ambas relacionadas à concepção parte-todo. Na primeira, o sujeito dividir cada pizza em quatro partes iguais, destinando a cada pessoa cinco dessas partes, concluindo que cada um recebe 5/4 de pizza.[...]. Na segunda, decide distribuir uma pizza inteira para cada pessoa e dividir a última, em quatro partes iguais, concluindo que a cada pessoa corresponde $1 \frac{1}{4}$ de pizza. (SILVA, 2005, p. 122).

Então dentro das possibilidades discutidas por Silva (2005), proporemos as questões 7 e 8 da maneira como está na figura 35.

Figura 32 - Questões 7 e 8

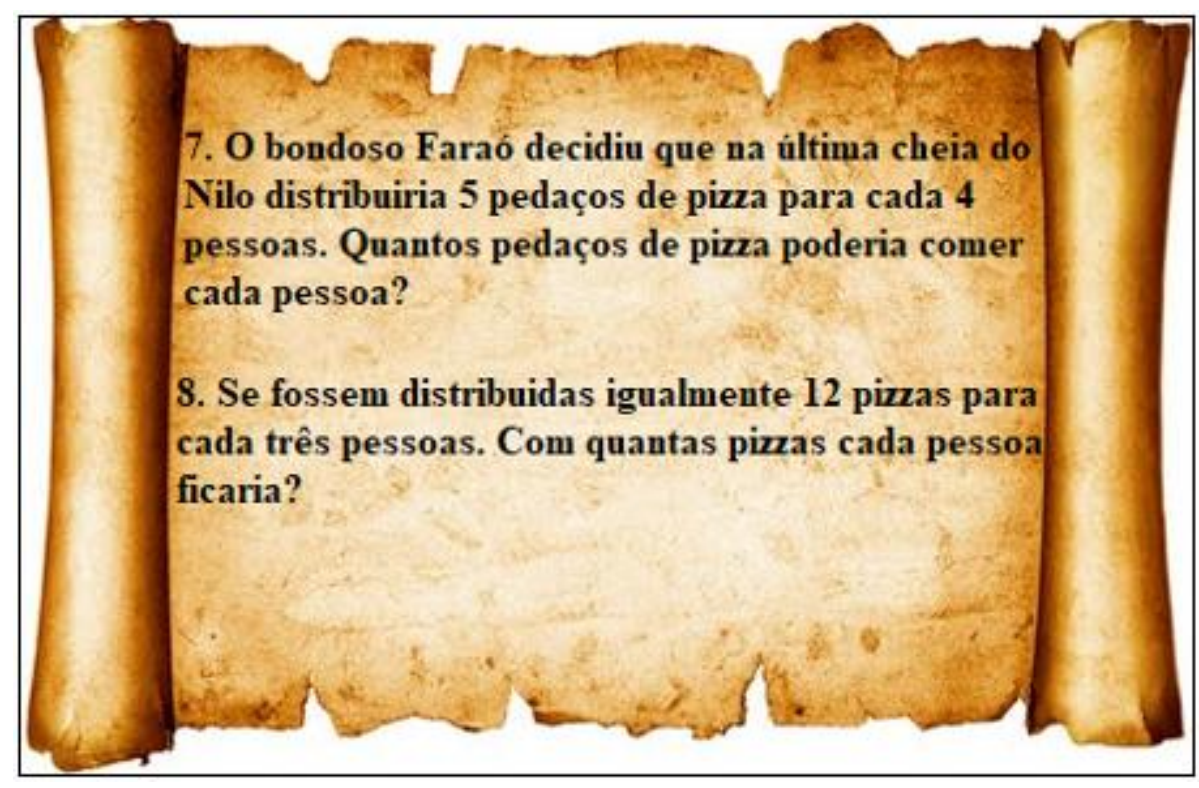

Fonte: Adaptado de Silva (2005, p. 122,123) 
As questões propostas na figura 35 foram adaptadas dos estudos de Silva (2005) fazendo parte de uma narrativa proposta dentro da sequêcia didática aos alunos do fundamental II, mais especificamente, sexto ano. As questões fazem alusão as ideias de quociente.

\section{Questão 9}

A ideia de razão faz parte do desenvolvimento da questão 9. Para elaboração da questão 9 utilizamos uma questão dos estudos de Silva (2005) e fizemos algumas adaptações para a narrativa da sequência didática. Mostramos abaixo a figura (36) que traz a questão original.

Figura 33 - Questão determinar uma razão

A miniatura de um objeto tem $12 \mathrm{~cm}$ de comprimento. Se na realidade esse objeto tem $60 \mathrm{~cm}$ de comprimento, qual foi a escala utilizada?

Fonte: Retirado de Silva (2005, p. 125)

Na questão proposta por Silva (2005), ela diz que “A determinação da razão em tarefas desse tipo permite definição da escala, como sendo a razão entre a medida de um comprimento em um desenho ou miniatura e a medida correspondente no objeto real." (SILVA, 2005, p.126). Com isso utilizamos a questão na sequência didática para aproximar o conceito de razão com os alunos. 
Figura 34 - Questão 9

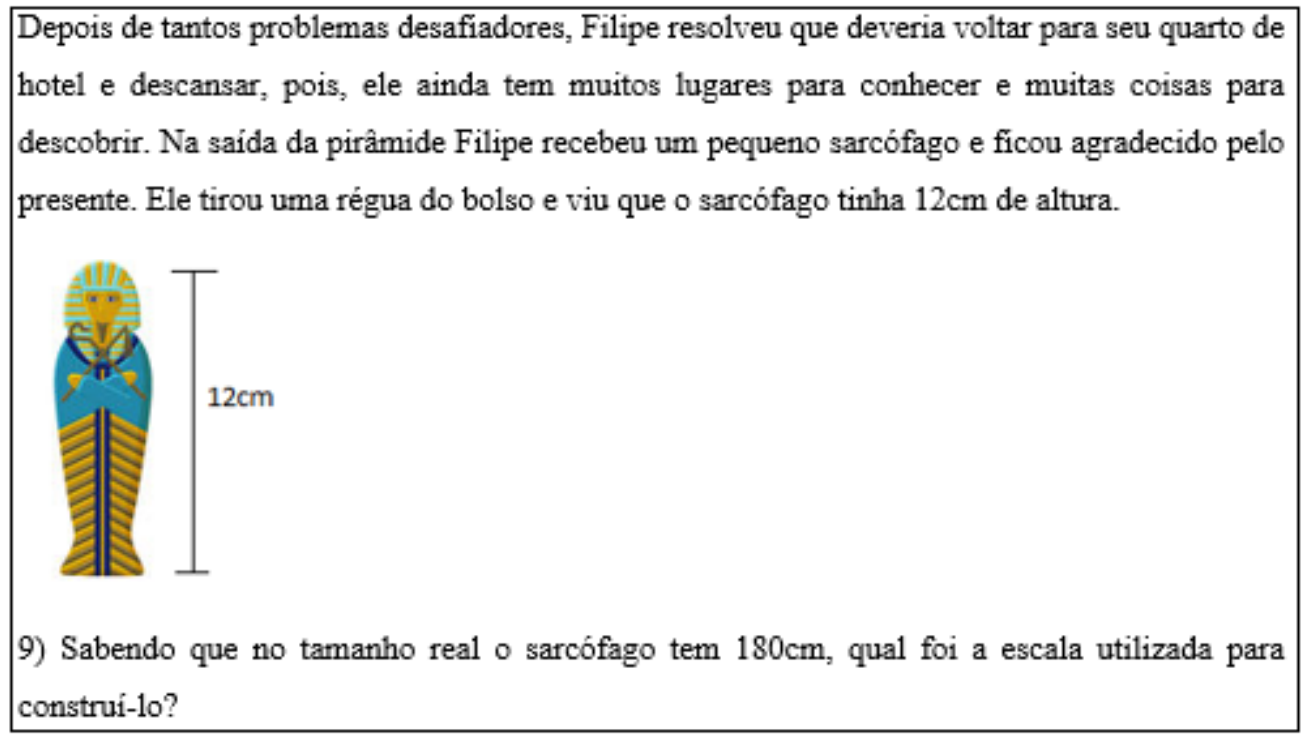

Fonte: Adaptado de Silva (2005, p. 126)

Como a questão foi adaptada de Silva (2005) então buscamos com isso trazer uma discussão sobre os conceitos de razão para a sala de aula.

\section{Questão 10}

Para o desenvolvimento da questão 10 utilizamos as ideias de operador seguindo a proposta de Silva (2005) de "transformar grandezas pela ação de dois operadores fracionários."

Como a ação de um operador fracionário, sobre um inteiro ou unidade, confunde-se, como já vimos, com a concepção de parte-todo de fracionários. A ação de mais do que um operador sobre um inteiro/unidade ou parte dele caracteriza melhor a ação de operadores e sua interpretação, essencialmente numérica. (SILVA, 2005, p. 136).

Buscamos então utilizar a ação de um ou mais operadores fracionários através da adaptação da questão que mostramos na figura 38 .

Figura 35 - Operador fracionário

Se a capacidade de $3 / 5$ de um recipiente é de 36 litros, qual a capacidade do recipiente? 
Fizemos então a adaptação da questão proposta por Silva (2005), para que pudesse ser utilizada na narrativa e compreendida pelos alunos conforme a imagem abaixo.

Figura 36 - Questão 10

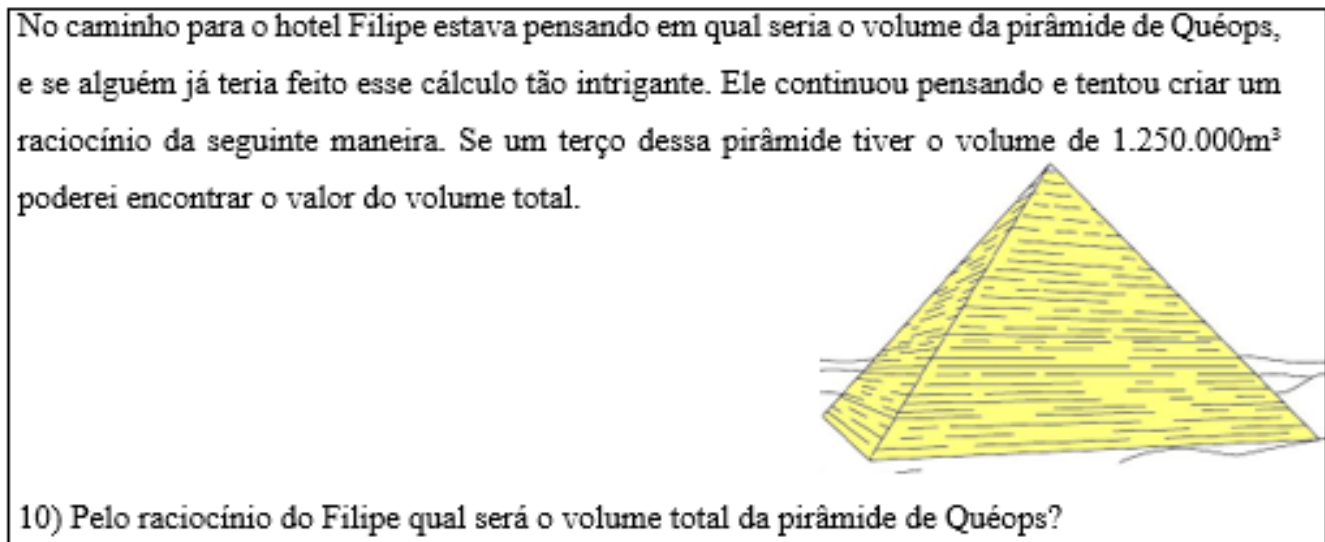

Fonte: Adaptado de Silva (2005, p. 126)

Os alunos poderão resolver essa questão utilizando a concepção de operador fracionário e partindo do princípio de que um terço do volume da pirâmide já foi informado, então o cálculo de três vezes o terço do volume da pirâmide resultará no volume total. 


\section{CAPÍTULO 5 - Análise, Resultados e Conclusões}

Nesse capítulo faremos a análise dos acontecimentos durante a aplicação da sequência didática, discutiremos os resultados do ponto de vista das situações didáticas e por fim faremos as considerações finais e conclusões do trabalho apresentado.

\subsection{Análise da Aplicação}

Investigando os acontecimentos durante a aplicação da sequência didática, usando como base para as aplicações o referencial teórico, podemos analisar o desenvolvimento dos alunos em meio a esses problemas que lhes foram propostos.

A priori, podemos dizer que o momento da devolução ao qual os alunos estiveram sujeitos teve suas expectativas atingidas, ou seja, os alunos aceitaram a responsabilidade de tentar resolver os problemas propostos. Tentamos evitar o paradoxo da devolução apresentado por Brousseau, que diz:

Um primeiro paradoxo da devolução é que, embora o professor deseje que o aluno elabore a resposta com seus próprios meios, também quer - e tem o dever social de querer - que o aluno dê a resposta correta. Deve, então, comunicar esse saber sem precisar revelá-lo, o que é incompatível com uma relação contratual. (Brousseau, 2008, p.91).

Embora em algum momento os alunos tenham acenado em busca de uma ajuda para a questão, consideramos que eles precisavam se envolver completamente nos problemas e buscar pensar de acordo com a situação proposta, ou seja, tentar todas as possibilidades de resolução do problema antes de recorrer ao professor.

Analisaremos agora as questões e as soluções e desafios encontrados e discutidos pelos alunos durante a aplicação da sequência didática.

\section{Questão 1}


Depois que todos os alunos haviam recebido as questões da primeira aula eles pegaram o material (lápis, borracha e caneta) para resolução das questões e sentaram-se de maneira a desenvolver seu raciocínio individualmente. Passados aproximadamente 10 minutos todos os alunos já haviam respondido o primeiro problema. As figuras abaixo mostram algumas resoluções do primeiro problema de diferentes formas.

Figura 37 - Resolução do aluno D questão 1

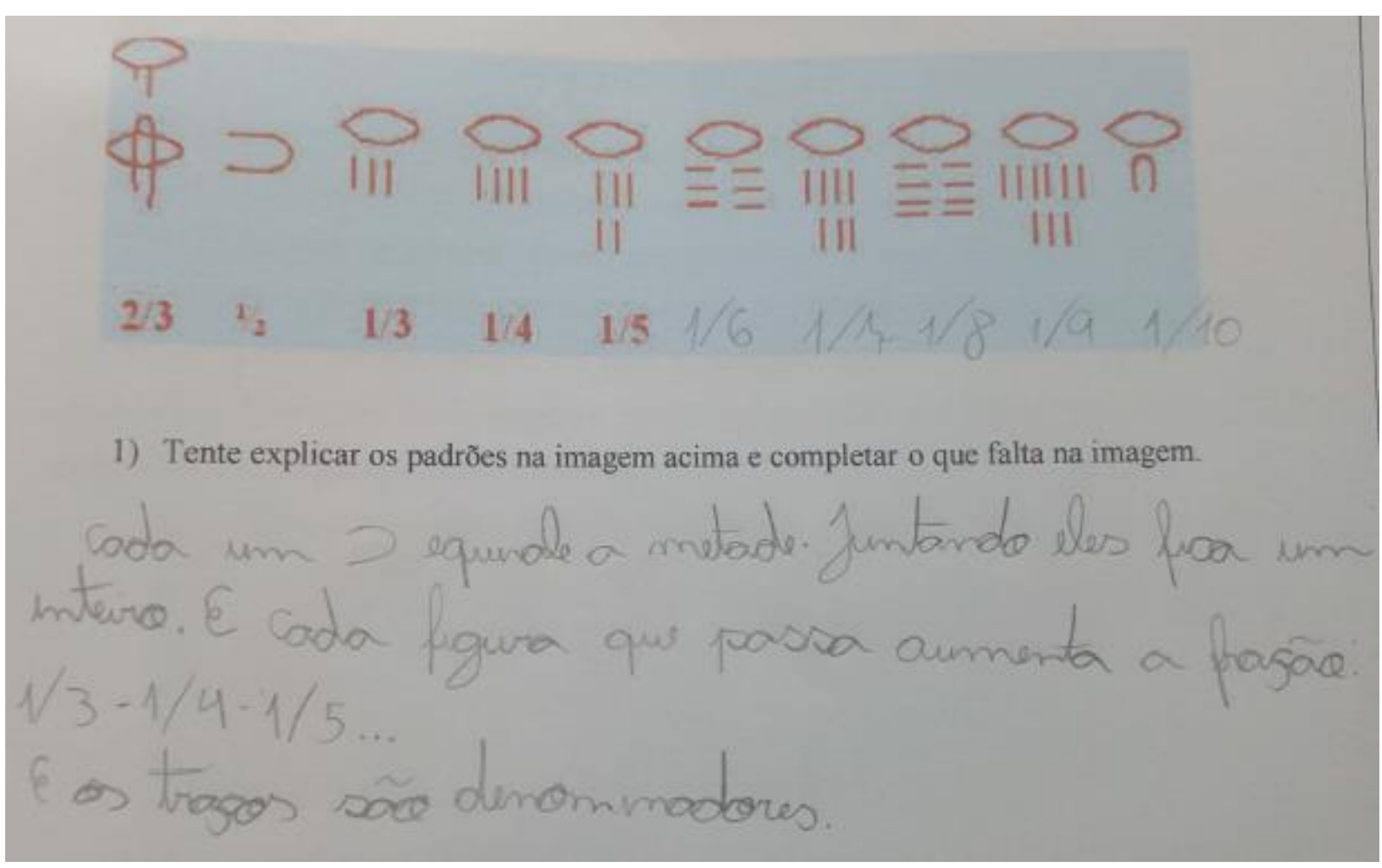

Fonte: Autor

O aluno D desenvolveu seu raciocínio levando em consideração as informações contidas na imagem. Ele desenvolve uma relação entre o símbolo egípcio usado para a unidade do numerador e sua metade, e concluiu afirmando que os "traços" são denominadores.

Nos momentos em que os alunos resolviam a questão de forma individual, muitos alunos tentavam fazer com que o professor fizesse algum sinal de aprovação ou de reprovação do que estava sendo construído em suas respostas, o professor por sua vez deixou a análise dos resultados e suas tentativas para que os alunos pudessem experimentar o momento da ação. Mostro ainda outro exemplo de resolução do problema 1 na figura seguinte. 
Figura 38 - Resolução do aluno B questão 1

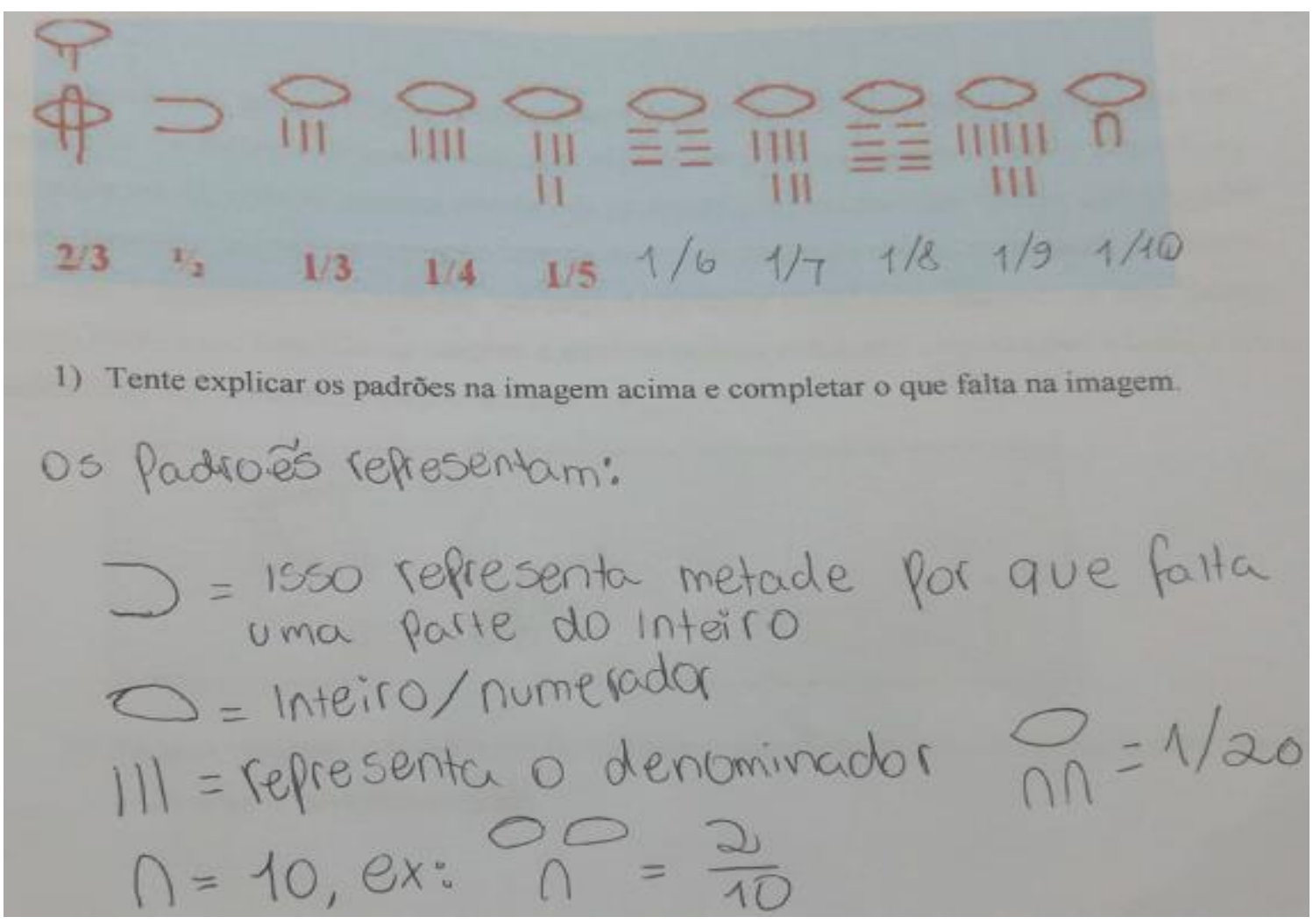

Fonte: Autor

O aluno B segue uma linha de raciocínio que vai ao encontro do aluno $\mathrm{D}$, porém ele tenta generalizar de alguma forma o que seriam os possíveis valores para o numerador. Podemos ver em sua resposta um exemplo da fração egípcia representando a fração $\frac{2}{10}$ de forma a colocar dois símbolos que representariam a unidade e um símbolo abaixo representando a dezena.

Tivemos um total de 36 respostas ao primeiro problema apresentado na sequência didática, muitos alunos seguiram com o raciocínio apresentado pelos alunos D e B, mudando somente a forma de explicar o mesmo problema.

\section{Discussão do primeiro exercício}

Conforme explicado na metodologia, os alunos começaram a discutir em grupos de dois ou mais a resolução do exercício. O aluno que conseguisse convencer os membros do grupo da certeza de seu resultado deveria apresentar a resposta na lousa para que todos 
os alunos pudessem verificar a validade da resposta dada, ou refutá-la iniciando assim uma discussão entre as partes, que pudesse ser oportunamente mediada pelo professor. Abaixo segue a imagem da resolução do problema 1 na lousa.

Figura 39 - Resolução do problema na lousa - Aluna $S$

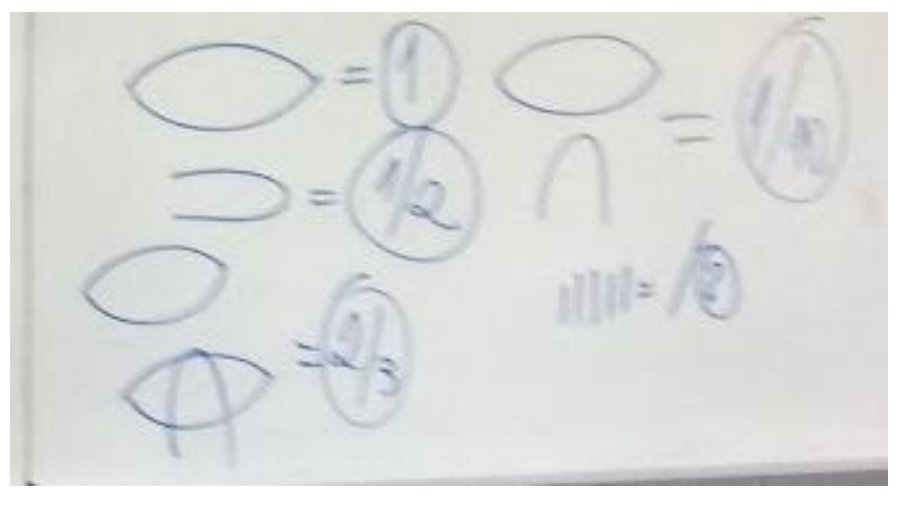

Fonte: Autor

A imagem mostra como a aluna $\mathrm{S}$ resolveu o problema na lousa depois de discutir com o grupo quais as possíveis soluções. No áudio a aluna $\mathrm{S}$ diz o que seguinte:

Aluna $\mathrm{S}-$ Eu acho que isso daqui é metade por que é a metade desse outro aqui, tipo inteiro. Esse aqui é dois terços porque são dois tipo inteiros dividido em três. Cada um desse daqui representa o denominador, e esse daqui representa um dez.

A aluna S começa sua fala comparando o símbolo usado para o numerador nas frações egípcias com um inteiro e a metade desse símbolo iria gerar um inteiro dividido em duas partes, por isso, um meio. Depois a aluna compara novamente o inteiro que dessa vez teria, na opinião dela, dois inteiros divididos em três partes, por isso ela diria os dois terços. Por último a aluna $\mathrm{S}$ diz que cada símbolo em formato de barra em baixo do símbolo do inteiro representa o denominador.

Os alunos vivenciaram situações de ação no momento em que tiveram que pensar e repensar no resultado e em suas possibilidades de resolução, com isso em mãos os alunos começaram a usar as ideias de formulação comparando e verificando para os outros resultados. Para que eles pudessem vivenciar uma situação de validação, os alunos foram agrupados e precisaram discutir seus resultados com os outros colegas para validar suas respostas e a de seus colegas, discutindo as ideias e estratégias para se resolver os 
problemas. Depois da discussão, quando a aluna vem à lousa, o professor sugere que os alunos apresentem contrapontos ao resultado da aluna, nesse caso os alunos não fizeram nenhum comentário.

Nesse momento acredito que faltou uma institucionalização por parte do

professor, para alinhar questões como as que o aluno colocou tentando fazer $\frac{2}{10}$. A falta dessa discussão não contribui para formar os passos da situação didática, o professor poderia ter colocado a resposta de alguns alunos na lousa para comentários e fechamento de maneira a usar a parte da institucionalização nos moldes de Brousseau.

\section{Questão 2}

Na segunda questão estava envolvido implicitamente o conceito de parte-todo de acordo com estudos de Silva (2005). Os alunos continuaram na leitura do problema na sequência didática e resolveram o problema proposto. Colocamos nas próximas figuras algumas das resoluções do segundo problema. 


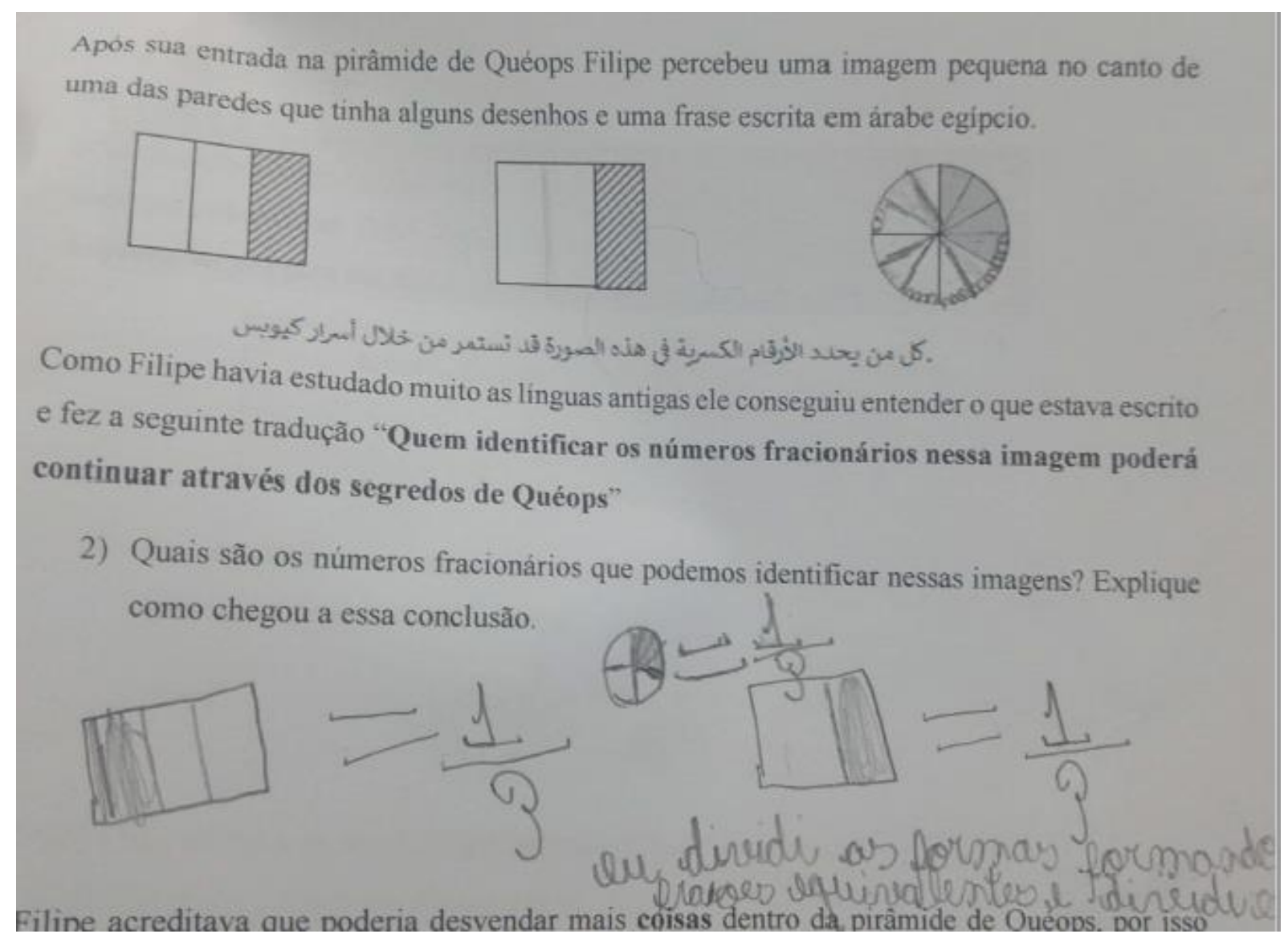

Fonte: Autor

Observamos que o aluno $\mathrm{C}$ foi capaz de elaborar situações diversas para o problema e ficou interessado na sua resolução. Repartindo as figuras para que tivesse uma quantidade igual de espaços para serem preenchidos o aluno desenvolveu seu raciocínio e analisou as possibilidades incluindo possíveis simplificações das frações como na resposta do círculo não dividido em partes iguais, que o aluno buscou primeiro dividi-lo para depois fazer a contagem.

Alguns alunos tiveram outra ideia na resolução da segunda questão. Separaram entre partes visivelmente pintadas e não pintadas indiferentemente do tamanho em questão. 


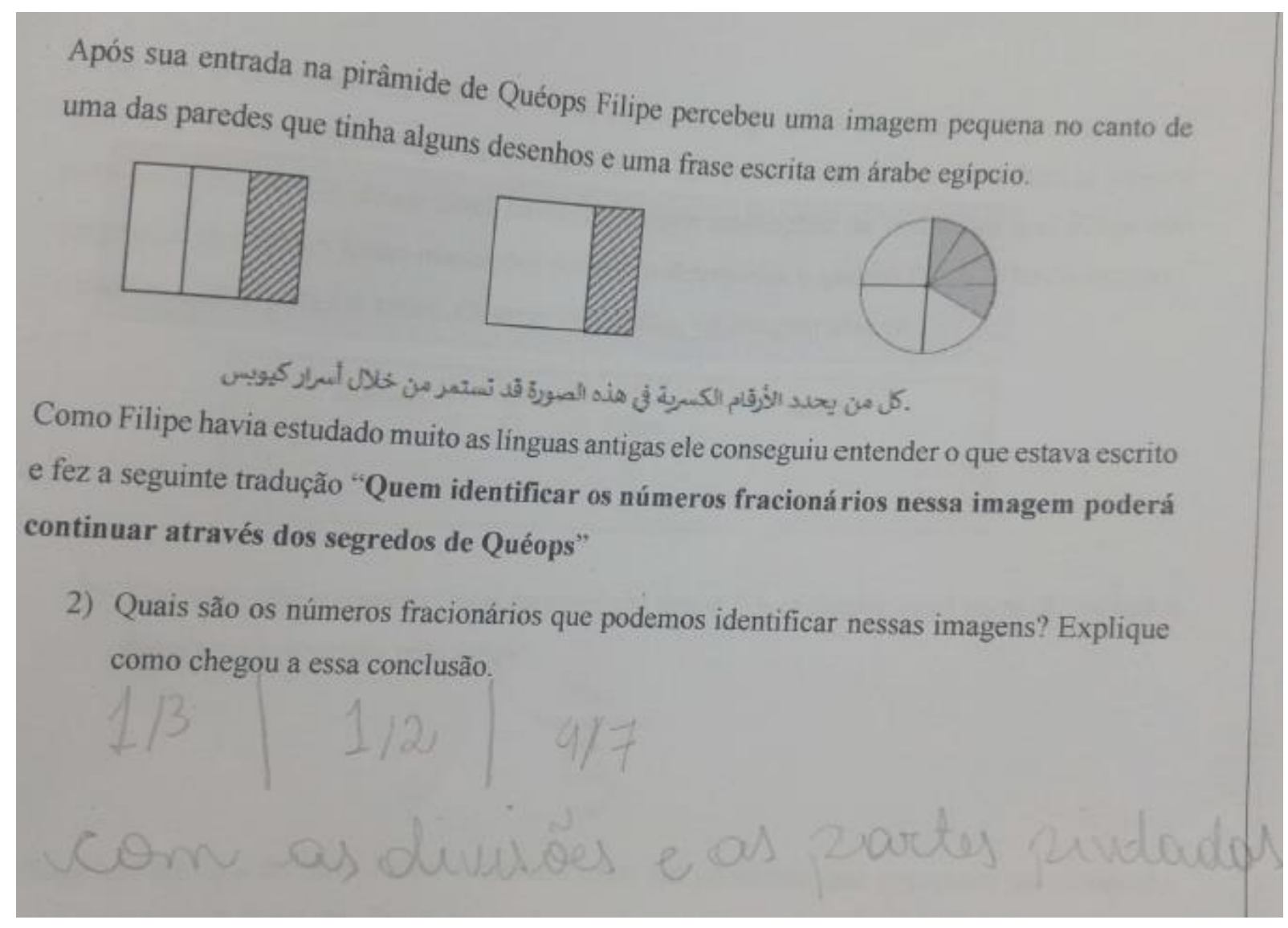

Fonte: Autor

O aluno fez sua resolução do problema utilizando como ponto de partida as divisões que já estavam feitas na figura, então na primeira figura o aluno encontrou $\frac{1}{3}$, na segunda figura $\frac{1}{2}$ e na última figura ele encontrou $\frac{4}{7}$. Nesse caso o aluno não se preocupou com partes iguais, ele usou somente a contagem dupla que seria o número de partes pintadas dividido pelo total de partes da figura.

\section{Discussão da questão 2}

Os alunos sentaram-se em grupos para discutir as estratégias de resolução para a questão

2, discutiram por aproximadamente uns 10 minutos e depois disso um dos alunos foi até a lousa para fazer a resolução dos exercícios, conforme mostra a imagem abaixo. 
Figura 42 - Resolução na lousa Questão 2

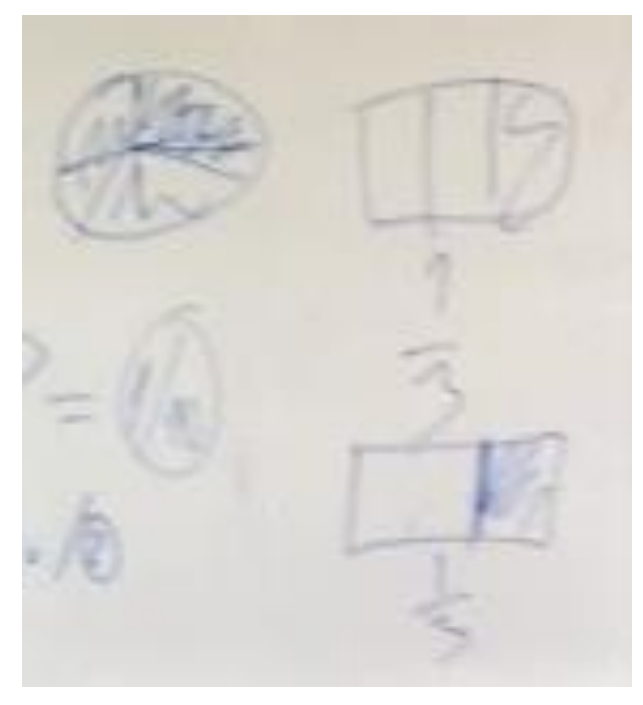

Fonte: autor

Vemos nessa imagem a resolução do aluno T na lousa, após a discussão com seu grupo e colegas de classe sobre as possíveis abordagens e resoluções dos problemas propostos. Durante sua explicação, houve algumas intervenções na sala de áudio conforme a descrição do áudio a seguir:

Aluno T - eu achei que as três imagens representavam um terço de tudo assim neh, tipo um terço.

$\mathrm{R}$ - Certo. E aí?

Aluno T - E aí aqui tem tipo, assim neh, aí ta pintado um terço da imagem porque se colocar outro traço aqui iria ficar 3 . Então para mim isso que tinha que fazer.

Aluno T - aí aqui tem um círculo.

Aluno M - Faz maior.

Aluno T - Aí aqui ó, tá desenhado aqui um terço da imagem.

Aluno M - Explica direito.

Aluno T - Eu não sei, um terço porque é um terço da imagem.

Durante a discussão alguns alunos não ficaram satisfeitos com a explicação do aluno $\mathrm{T}$ da divisão do círculo em partes iguais, então o aluno $\mathrm{M}$ se propôs a explicar a questão como mostramos na descrição do áudio a seguir:

Aluno M - é assim que está pintado, e cada neh negócio assim tá dividido em três partes, então só se acabar de dividir tudo em três partes. Aí você dividiu tudo em três partes, tudo em três partes vão ter doze partes pequenas e essas partes estão pintadas então quatro sobre doze que é a mesma coisa que um 
terço. É só você dividir por dois, vai dar dois de seis depois dividir por dois de novo que vai dar um terço.

Os alunos discutiram bastante a resolução da questão dois, a dúvida sobre igualar ou não igualar as partes que não estavam divididas no círculo fez com que eles pensassem muito sobre essa questão. Quando por fim o aluno M explicou sua forma de resolver a divisão do círculo, os alunos ficaram satisfeitos e preparados para fazer a questão 3.

\section{Questão 3}

Na terceira questão continuamos trabalhando o conceito de parte-todo, porém utilizando a ideia de reconstituição do inteiro parte-todo no contínuo proposta por Silva (2005). Os alunos conseguiam observar somente um terço de uma determinada imagem, e o texto pedia que eles completassem a imagem para que não houvesse somente a terceira parte dela, mas a imagem inteira. Para essa questão muitas soluções diferentes foram propostas, destacamos aqui algumas dessas soluções nas figuras abaixo.

Figura 43 - Resolução da questão 3 - Aluno $G$

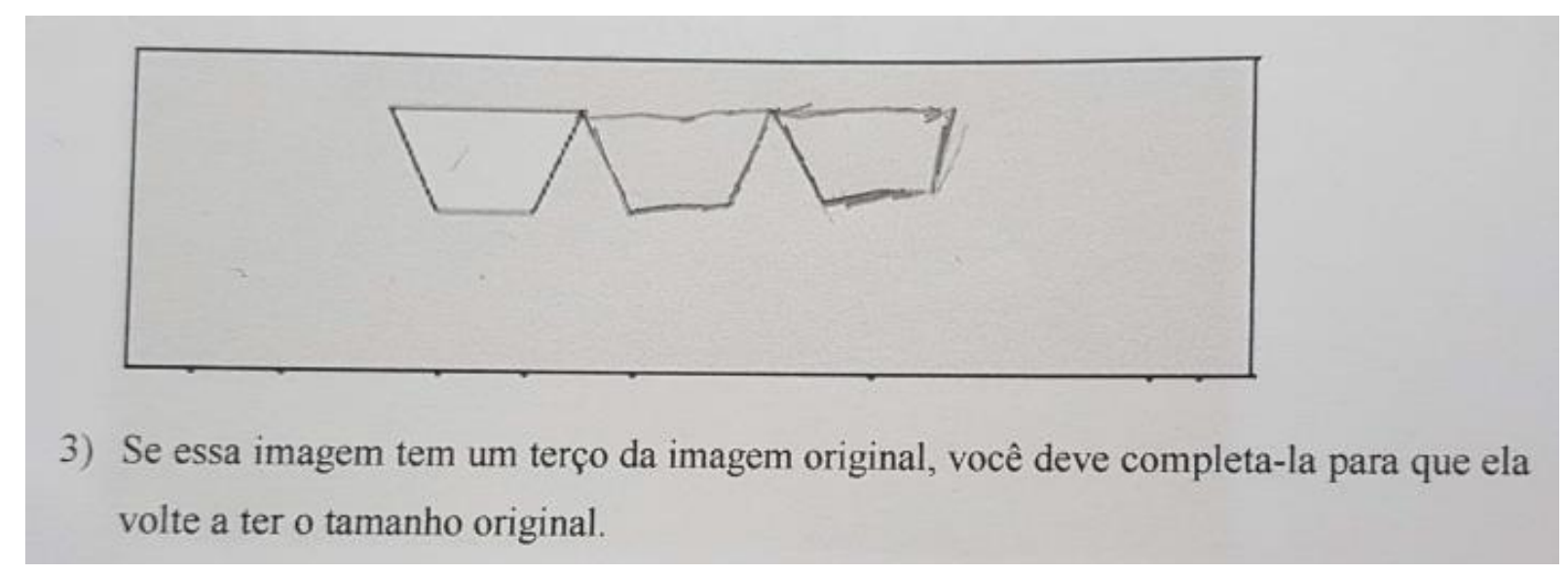

Fonte: Autor

O aluno $\mathrm{G}$ resolveu a questão 3, completando o que faltava para compor o todo. $\mathrm{O}$ aluno $\mathrm{G}$ demonstrou facilidade em lidar com esse problema. Esse problema foi resolvido de diversas maneiras diferentes pelos alunos, o esquema desenhado pelo aluno 
G também foi pensado por outros alunos da sala, outros porém tentaram propor mais de uma solução para o mesmo problema conforme imagem da resolução da aluna S.

Figura 44 - Resolução da questão 3 - Aluna S

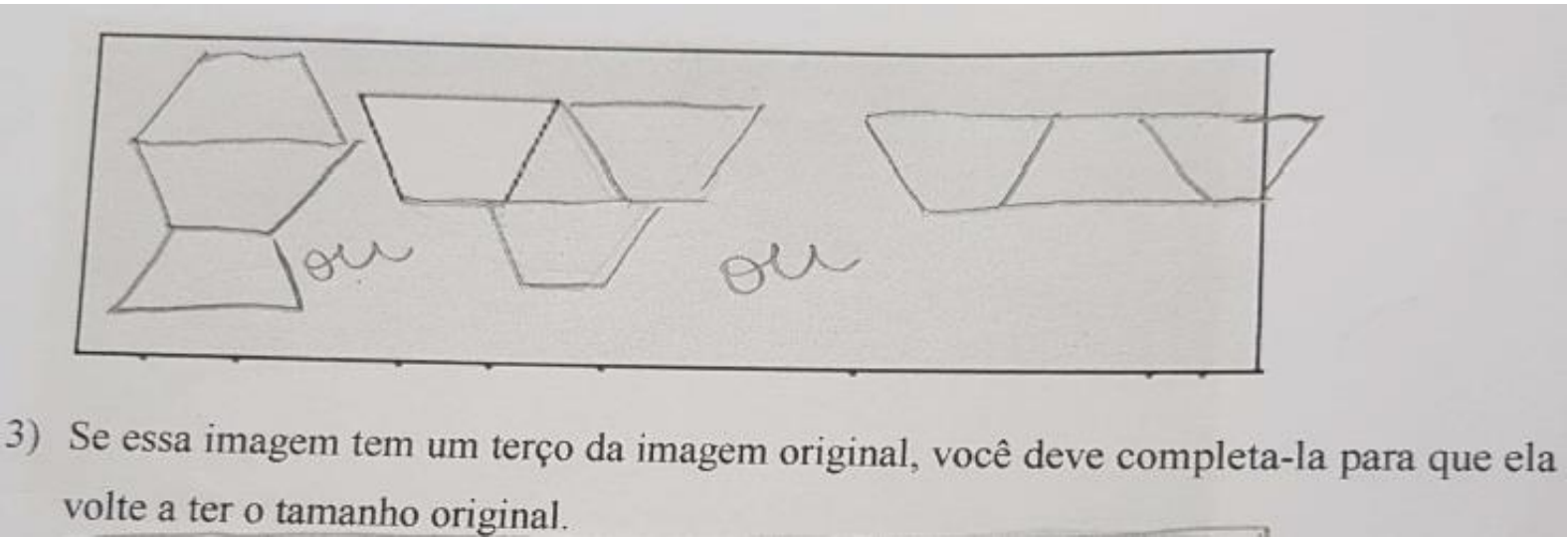

Fonte: Autor

Observamos na resolução oferecida pela aluna S uma bela compreensão do problema e de sua aplicação, a aluna explicou ainda para um grupo de 5 alunos durante o período de discussão do problema e com isso pode validar o que havia aprendido.

\section{Discussão da questão 3}

Os alunos se reuniram em grupos de dois ou mais para discutir a questão e validar as suas soluções e refutar ou validar as soluções dos outros membros do grupo. Depois de 5 minutos de discussão os alunos já estavam preparados para apresentar suas resoluções para a sala. Assim o aluno M veio até a lousa explicar como havia resolvido a questão 3, e abaixo uma imagem com relação a sua resolução. 
Figura 45 - Resolução da questão 3 - Aluno M

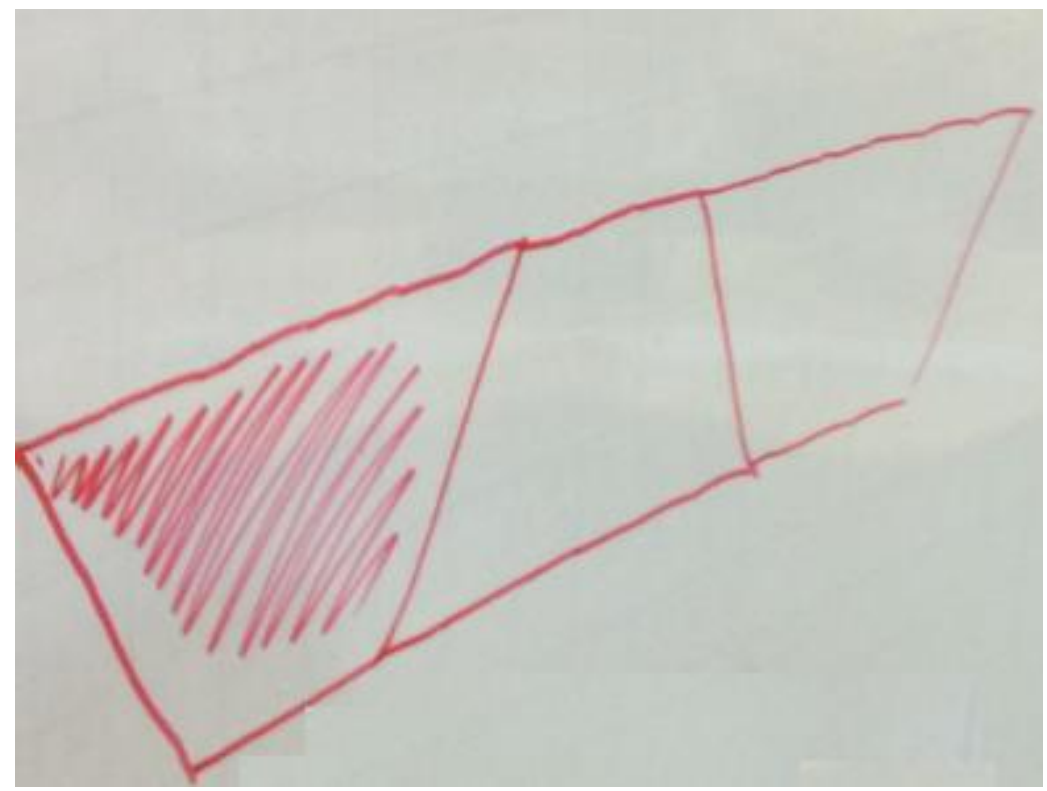

Fonte: Autor

$\mathrm{Na}$ figura $\mathrm{X}$ mostramos a resolução da questão pelo aluno $\mathrm{M}$, o aluno explicou o seu pensamento para resolver essa questão conforme a descrição do áudio a seguir:

Aluno M - Essa imagem aqui já estava lá, e sabem que essa imagem é três vezes menor do que, é um terço neh, como ele já falou, da original. Então você tem que fazer isso aqui vezes três pra dar a imagem certa.

Após a explicação do aluno M, os outros alunos conseguiram pensar melhor e desenvolver outras formas de resolver a questão três, sendo uma etapa importante para a compreensão e assimilação do conceito parte-todo.

\section{Questão 4}

Para a questão 4 devemos lembrar que estamos trabalhando a noção de medida em frações, associada a exercícios propostos nos estudos de Silva (2005). E especificamente nesse caso os exercícios em que a autora propõe determinar medidas em segmentos divididos em partes iguais.

Os alunos precisavam determinar o quanto ainda faltava para que o personagem da história atravessasse um túnel sabendo de sua localização e das marcas de distâncias 
contidas no túnel. Mostraremos aqui algumas imagens relacionadas as soluções dos alunos.

Figura 46 - Resolução da questão - Aluno E

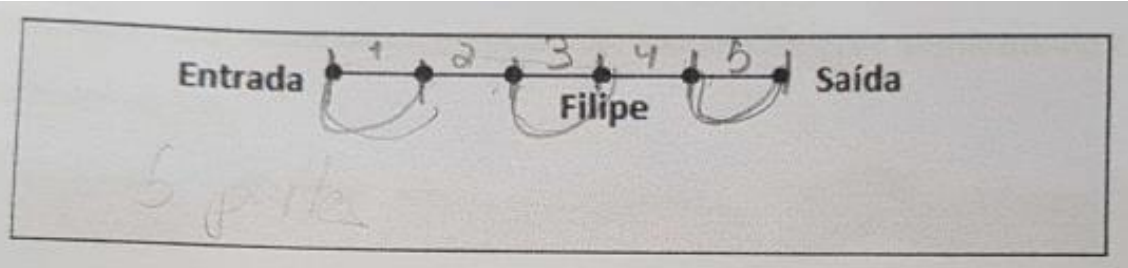

4) Considerando o tamanho total do túnel em que o Filipe estava, qual parte do caminho faltava ser percorrida pelo Filipe?

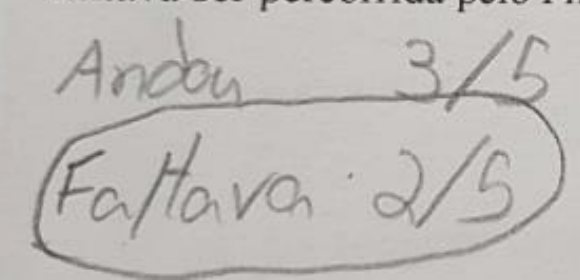

Fonte: Autor

O aluno E resolveu a questão 4, separando um tamanho de unidade para cada dois pontos de localização. Sendo assim, para ele, o segmento era dividido em 5 partes iguais que poderiam compor o segmento todo. Essa questão gerou nas turmas muita discussão devido à razão do que considerar quando se trata de definir distância entre o ponto inicial e o ponto final. Para alguns alunos, deveríamos considerar uma distância como sendo o deslocamento entre dois pontos; para outros, poderíamos contar com os pontos para determinar a distância total.

Mostramos abaixo a resolução do aluno H, que divergia da solução do aluno E: 
Figura 47 - Resolução da questão 4 - Aluno H

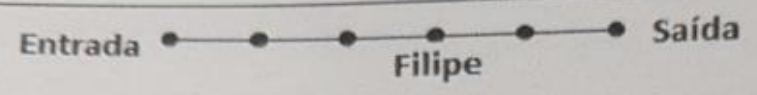

4) Considerando o tamanho total do túnel em que o Filipe estava, qual parte do caminho faltava ser percorrida pelo Filipe?

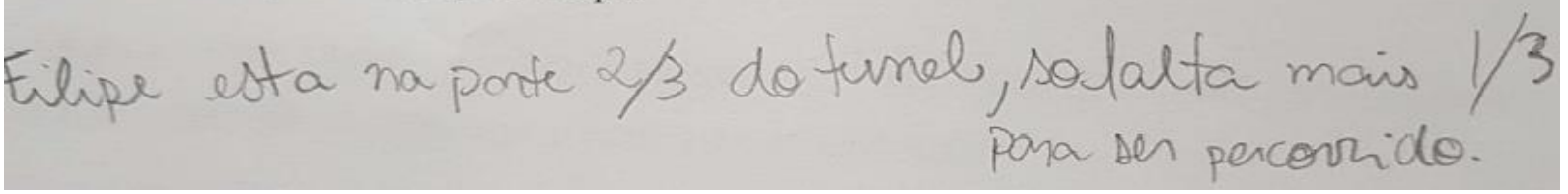

Fonte: Autor

Conforme vemos na imagem, o aluno $\mathrm{H}$ considerou a distância ponto a ponto, ou seja, haviam 6 pontos no caminho, o personagem da história estava no ponto 4 , faltavam então 2 pontos de 6 para chegar a saída.

\section{Discussão da questão 4}

Para discutir a questão 4 os alunos sentaram-se em grupos de dois ou mais alunos e começaram a defender sua resolução. Eles discutiram a questão por aproximadamente 10 minutos, depois apresentaram à sala de aula. $\mathrm{O}$ aluno que apresentou a resolução para ser discutida foi o aluno $\mathrm{J}$, mostramos abaixo a imagem referente à resolução da questão na lousa proposta pelo aluno $\mathrm{J}$. 
Figura 48 - Resolução da questão 4 na lousa

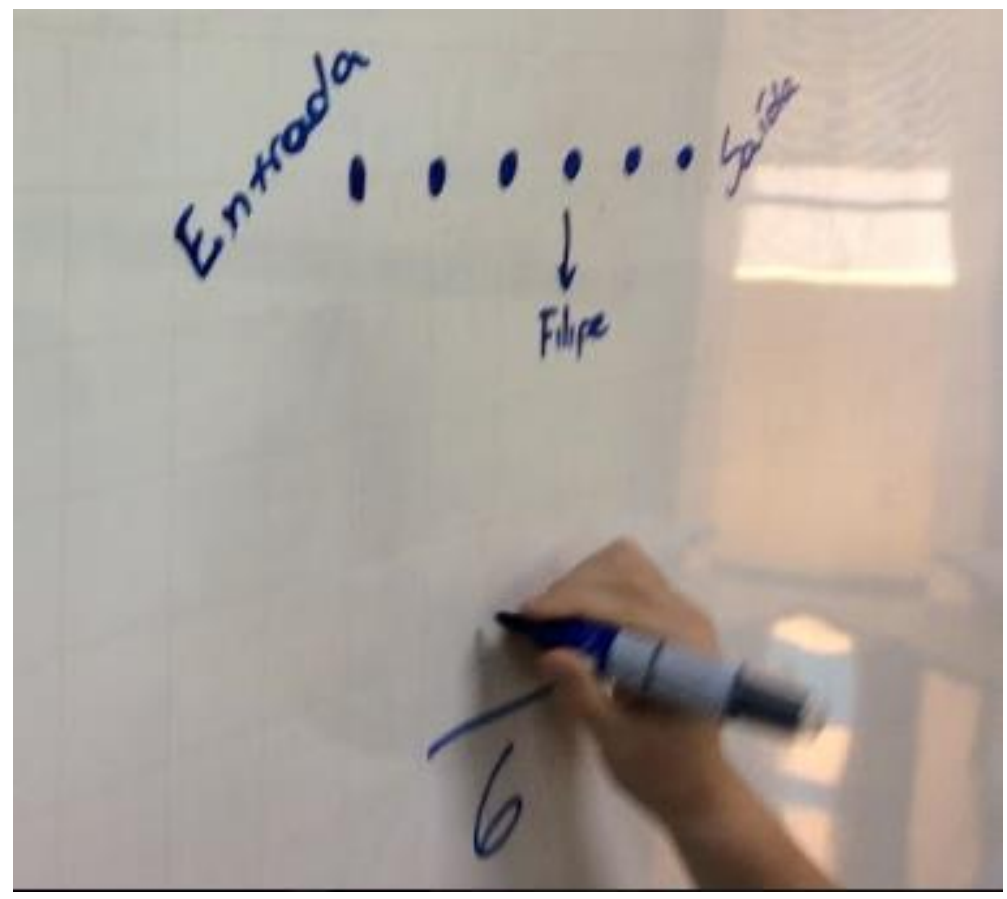

Fonte: Autor

O aluno desenvolveu o seu raciocínio para a resolução da questão utilizando a ideia do ponto a ponto, ou seja, cada ponto deveria representar uma parte do caminho. Durante a sua explicação houveram algumas intervenções feitas pelos outros alunos conforme a descrição do áudio abaixo:

Aluno J - Você tem que contar os pontos para saber o total, é seis. Ai depois você vê onde ele está, quanto falta? Dois. Então dois sextos.

Aluno T - Não é dois sextos.

Aluno $\mathrm{G}$ - é dois sextos.

Aluno M - Calma aí deixa eu explicar, isso é uma parte, essa é outra, essa é outra e essa é outra.

Aluno A - deixa eu explicar ó, não é a bolinha, porque a bolinha é diferente de uma parte, isso daqui é uma parte o espaço entre uma bolinha e outra! Então a resposta é dois quintos.

Depois de um longo momento de discussão os alunos convenceram-se de que a resposta mais adequada à questão seria $\frac{2}{5}$, porque eles deveriam considerar os espaços entre as bolinhas e não as bolinhas entre os espaços. A discussão fez muitos alunos repensarem e até mesmo prestar mais atenção nas próximas questões. 


\section{Questões 5 e 6}

As questões 5 e 6 são baseadas nos estudos de Silva (2005) com relação à reconstituição da unidade. A questão mostra uma situação em que o aluno precisa encontrar a terça parte que falta em uma figura que tem dois terços. Para isso os alunos podiam usar um instrumento de medida ou fazer uma comparação simples pelo próprio tamanho da figura. Mostramos abaixo algumas soluções encontradas pelos alunos.

\section{Figura 49 - Resolução das questões 5 e 6 - Aluno D}

\section{5) Como Filipe calculou a parte que faltava para desenhar o Cetro?}

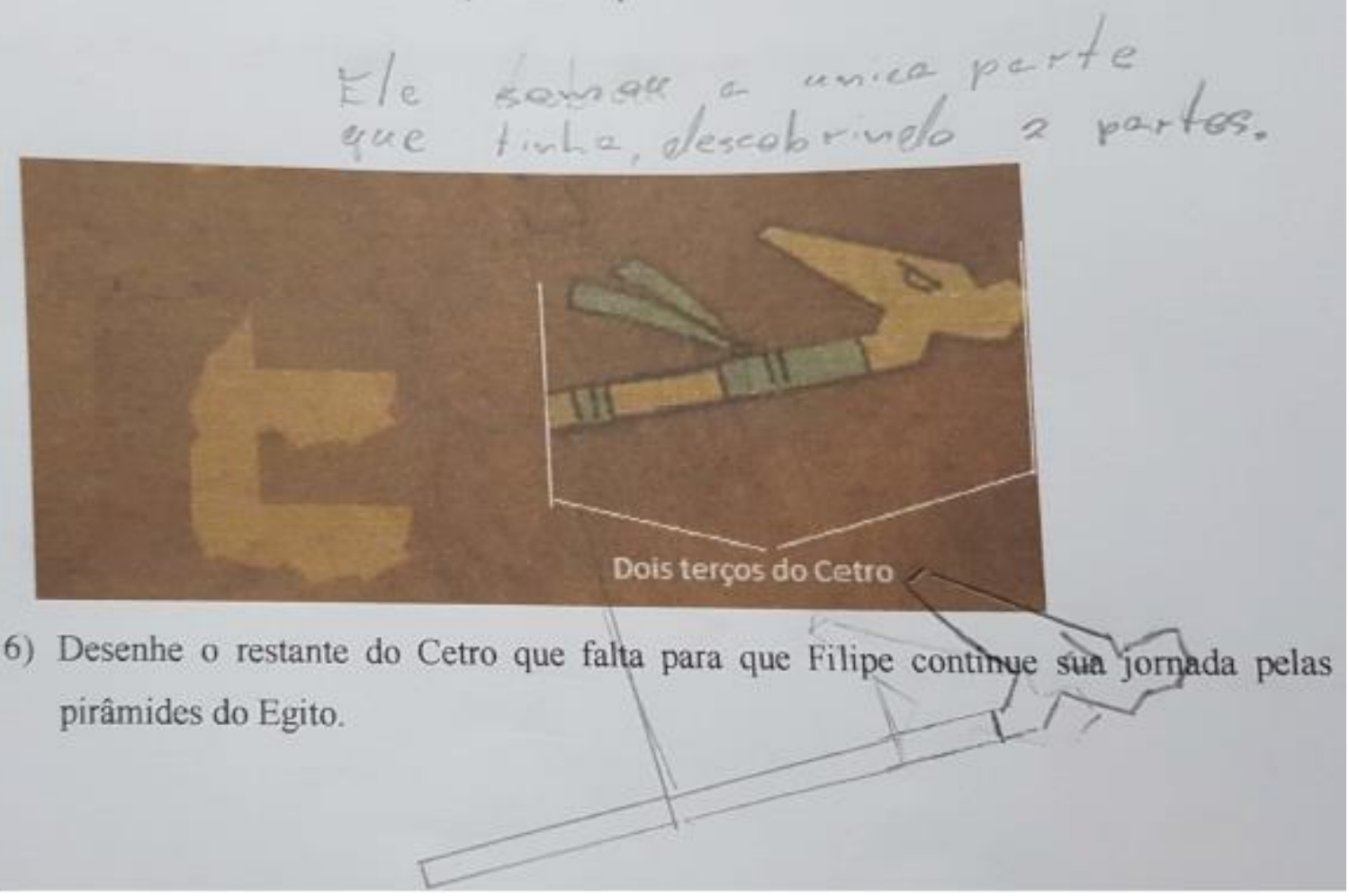

Fonte: Autor

Em sua resposta o aluno D levou em consideração as partes que o personagem da história já sabia que tinha, mais especificamente $\frac{2}{3}$, partindo dessa ideia o aluno conclui que o restante que falta para completar a imagem é de $\frac{1}{3}$. A resolução e o desenho do aluno ajudaram posteriormente outros alunos no momento da discussão do problema. Outra solução foi a que nos trouxe a aluna $S$, conforme imagem abaixo. 
Figura 50 - Resolução das questões 5 e 6 -Aluna $S$

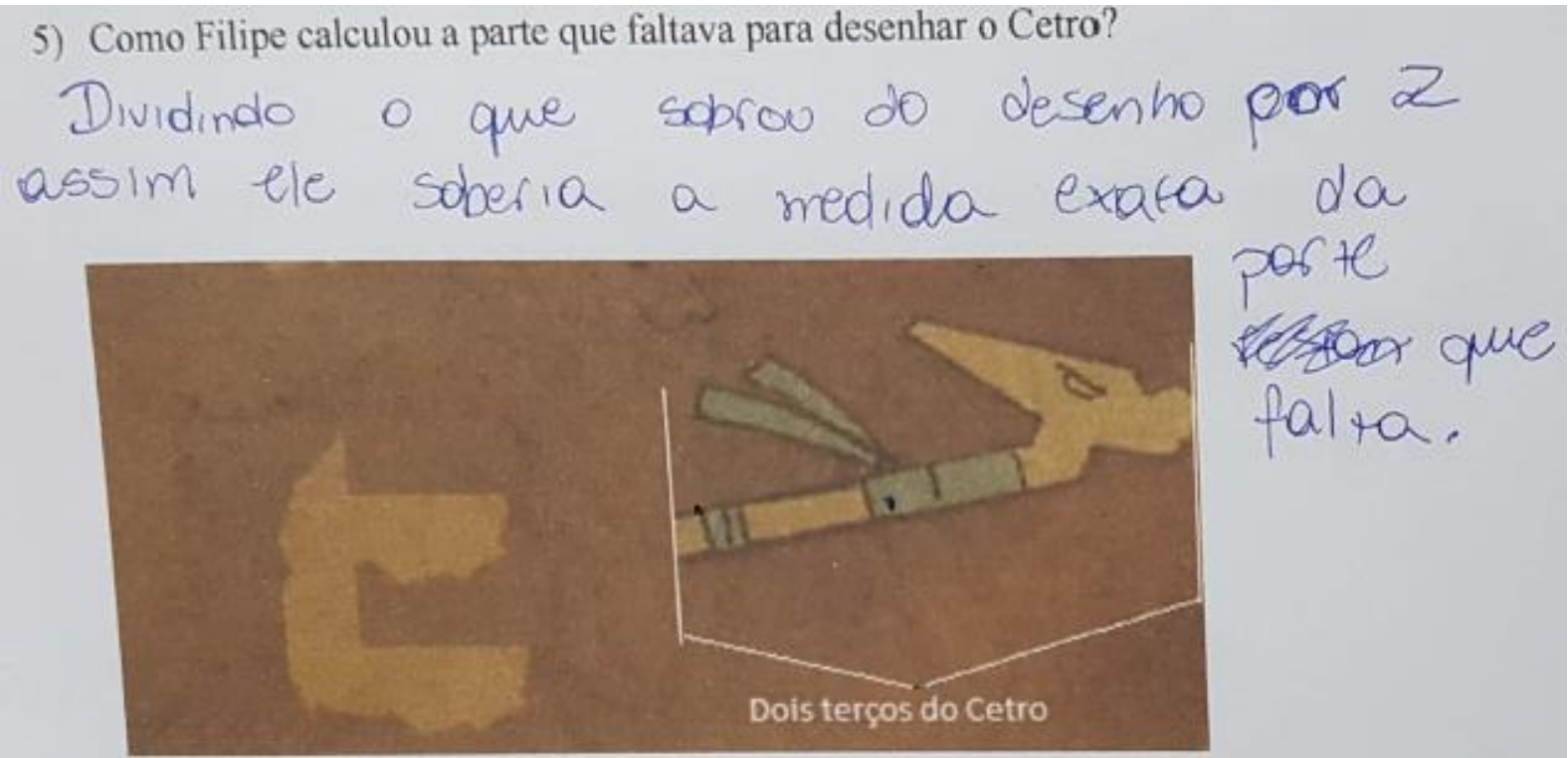

6) Desenhe o restante do Cetro que falta para que Filipe continue sua jornada pelas pirâmides do Egito.

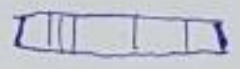

Fonte: Autor

A aluna $\mathrm{S}$ desenvolveu uma ideia que até então não havia aparecido nos outros alunos, ela pensou que se dividisse a quantidade de $\frac{2}{3}$ da figura por 2 , ela iria obter exatamente a medida que faltava, ou seja, $\frac{1}{3}$. Feito essa parte inicial a aluna conclui fazendo o desenho conforme mostra a figura, da quantidade que ela acredita representar exatamente a terça parte que falta.

\section{Discussão das questões 5 e 6}

A discussão das questões 5 e 6 seguiu com a colaboração em grupos de 2 ou mais alunos para a validação de suas respostas. Os alunos discutiram essa questão por pelo menos 5 minutos antes de prosseguirmos. Passado o momento da discussão o aluno B fez a sua resolução da questão na lousa. Trazendo para o grupo inteiro a sua resolução, os alunos participaram e discutiram ativamente buscando a melhor forma de fazer as divisões e o desenho pedido na questão. Abaixo a solução do aluno B na lousa. 
Figura 51 - Resolução lousa questões 5 e 6 aluno B

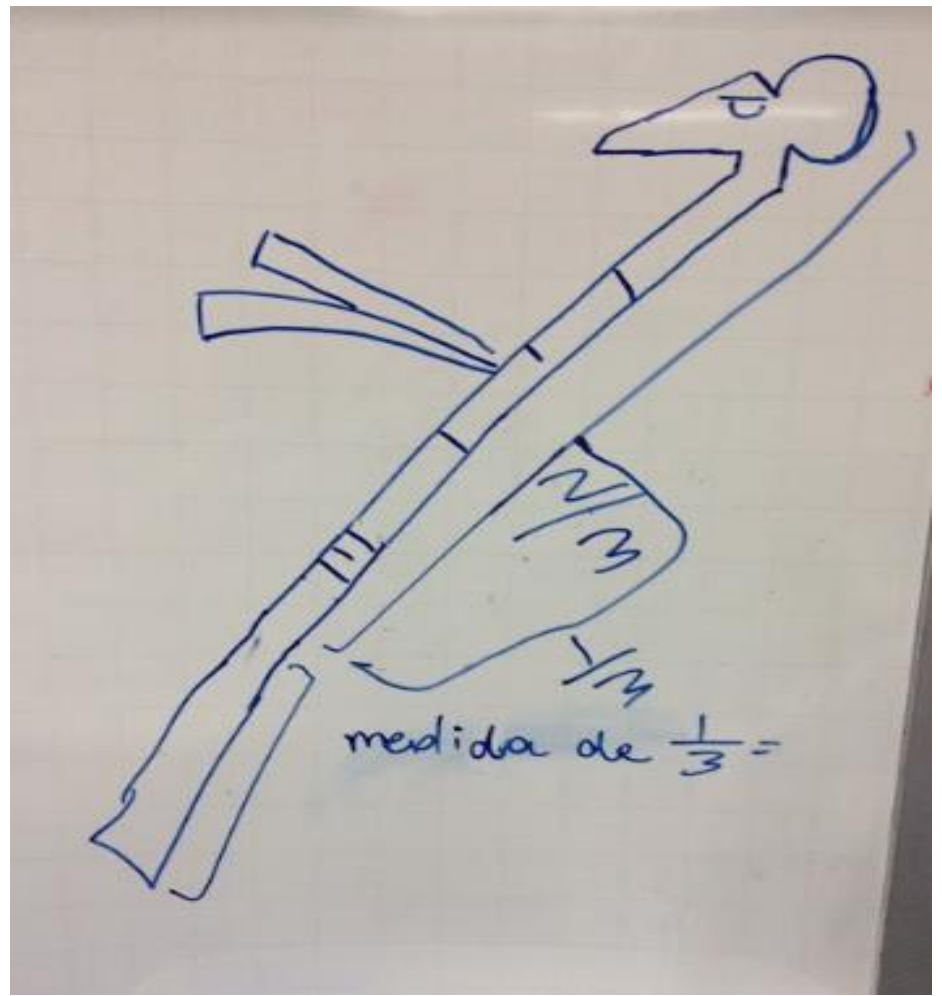

Fonte: Autor

Mostramos a seguir a descrição do áudio da explicação das questões 5 e 6 pelo aluno B:

Aluno B - a gente tem que achar a medida de um terço, então a gente vai dividir esses dois terços no meio.

$\mathrm{R}$ - Vocês viram que a ideia dele foi dividir dois terços ao meio, mais alguém teve essa ideia?

Aluno B - Aí ficaria mais ou menos aqui, então esse é o tamanho de um terço, então a gente adiciona esse tamanho de um terço no desenho.

A ideia que o aluno B defendeu foi a de que bastaria fazer a divisão do desenho da figura em duas partes, para então encontrarmos a parte da figura que falta, que nesse caso particular seria exatamente o tamanho de $\frac{1}{3}$. Os alunos participaram ativamente dessa discussão auxiliando aqueles que não haviam entendido e buscando outras ideias para resolver o problema posterior. 


\section{Questões 7 e 8}

As questões 7 e 8 foram adaptadas de questões utilizadas nos estudos de Silva (2005) e que tem como principal característica o uso da situação quociente na resolução e no significado das frações. Muitos alunos desenvolveram respostas parecidas em diferentes notações de números racionais, colocaremos nas imagens abaixo algumas das resoluções dos alunos e posteriormente a discussão das questões com o grupo e com a sala. Colocaremos primeiramente as questões 7 e 8 depois as resoluções dos alunos.

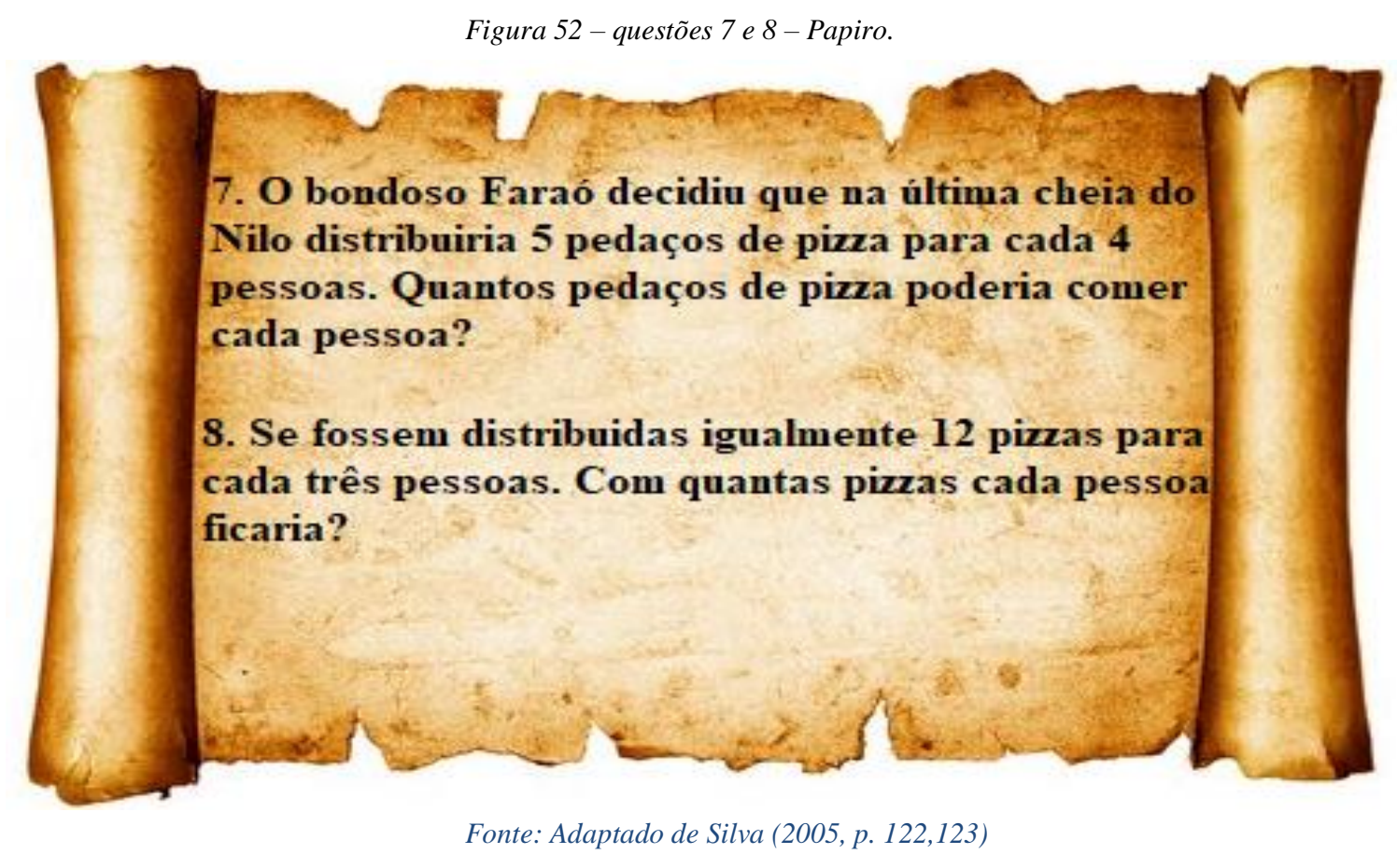

$\mathrm{Na}$ imagem acima vemos as questões 7 e 8 que os alunos precisaram responder. A grande maioria dos alunos trouxe uma nova questão para essas questões que dizia se de fato existia pizza no Egito antigo. Mesmo não sendo o alvo do estudo desse trabalho fiz uma pesquisa para rápida para que os alunos soubessem que apesar de não ter o mesmo nome, no Egito já existia sim princípios da culinária da pizza. Bona (2010) afirma o seguinte "Se examinarmos a origem histórica da pizza verificaremos que, do Egito à antiga Roma, foi criada uma série de iguarias que recordam, quer na sua composição quer em seu cozimento, a atual pizza". Com isso os alunos compreenderam uma nova história que até então era desconhecida por eles. 
Os alunos tiveram estratégias parecidas para resolver as questões 7 e 8, abaixo algumas imagens da resolução dos alunos e posteriormente a discussão das questões.

Figura 53 - Resolução das questões 7 e 8 -Aluna $L$

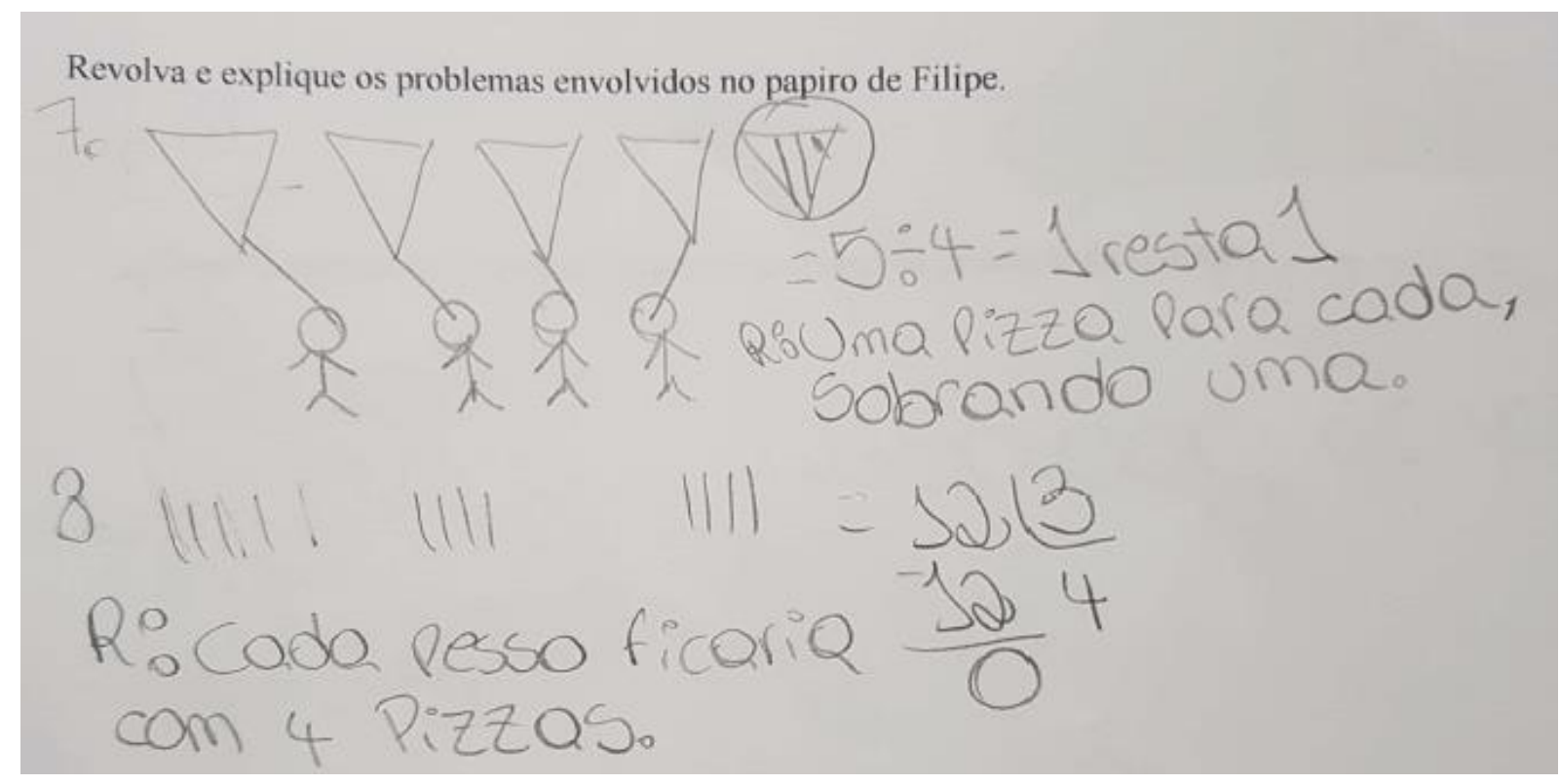

Fonte: Autor

Na resolução da questão 7, a aluna L considerou as opções em que cada pessoa ficaria exatamente com um pedaço de pizza, restando assim um pedaço que sobraria e ninguém o comeria. Quando a aluna responde a questão de número 8, utilizando o recurso da divisão de 12 por 4 , resultando assim o número 3, ou seja, na situação mencionada no enunciado e na resposta construída pela aluna L, cada pessoa ficaria com 4 pizzas. Seguindo um raciocínio parecido, mas sem deixar sobrar nenhum pedaço de pizza, o aluno $\mathrm{C}$ responde à questão conforme a imagem abaixo. 
Figura 54 - Resolução da questões 7 e 8 - Aluna C

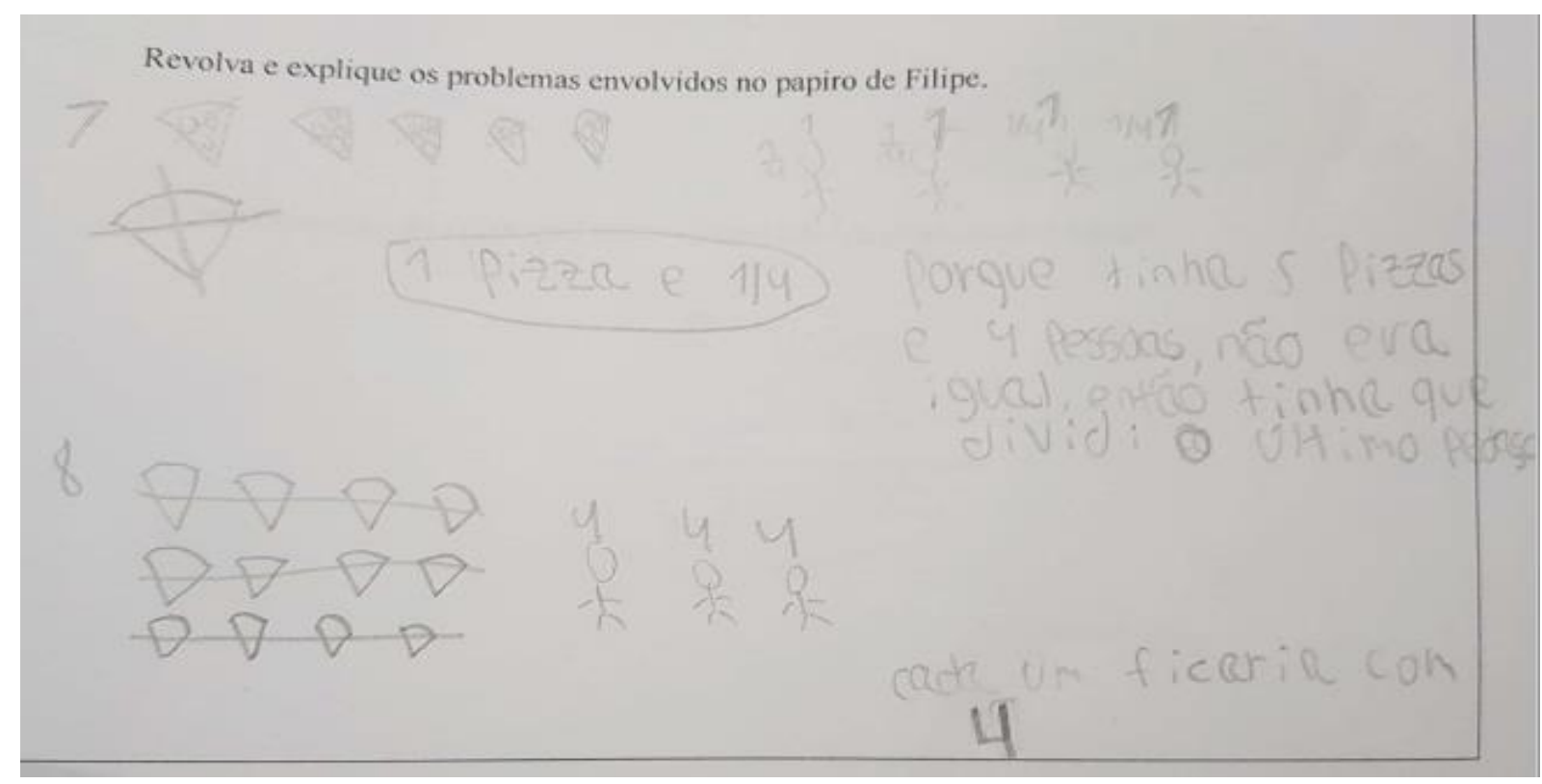

Fonte: Autor

Na resposta da questão 7 desenvolvida pelo aluno C observam-se ideias parecidas com as da aluna L. No entanto, quando sobra um pedaço de pizza o aluno o divide por

quatro resultando em $\frac{1}{4}$, ou seja, para ele cada pessoa deveria comer um pedaço de pizza e um quarto de um pedaço de pizza. Já na questão de número 8, o aluno desenvolve um raciocínio diferente do desenvolvido pela aluna L. O aluno, por seu turno, C faz os desenhos indicando a quantidade total de pizzas e depois as divide igualmente para que consiga visualizar com quantas pizzas cada pessoa irá ficar. Com isso, ele chega ao resultado 4 , como o da aluna $\mathrm{L}$.

Os alunos se envolveram bastante na discussão conforme mostraremos a seguir.

\section{Discussão das questões 7 e 8}

Para discutir as resoluções e os raciocínios desenvolvidos nas questões 7 e 8, os alunos sentarem-se em grupos de dois ou mais, buscando mostrar as possíveis resposta e validar, ou não, seu pensamento na resposta da questão. As discussões foram feitas com a sala inteira e o aluno D resolveu as questões na lousa conforme a figura abaixo. 
Figura 55 - Resolução das questões 7 e 8 na lousa - Aluno D

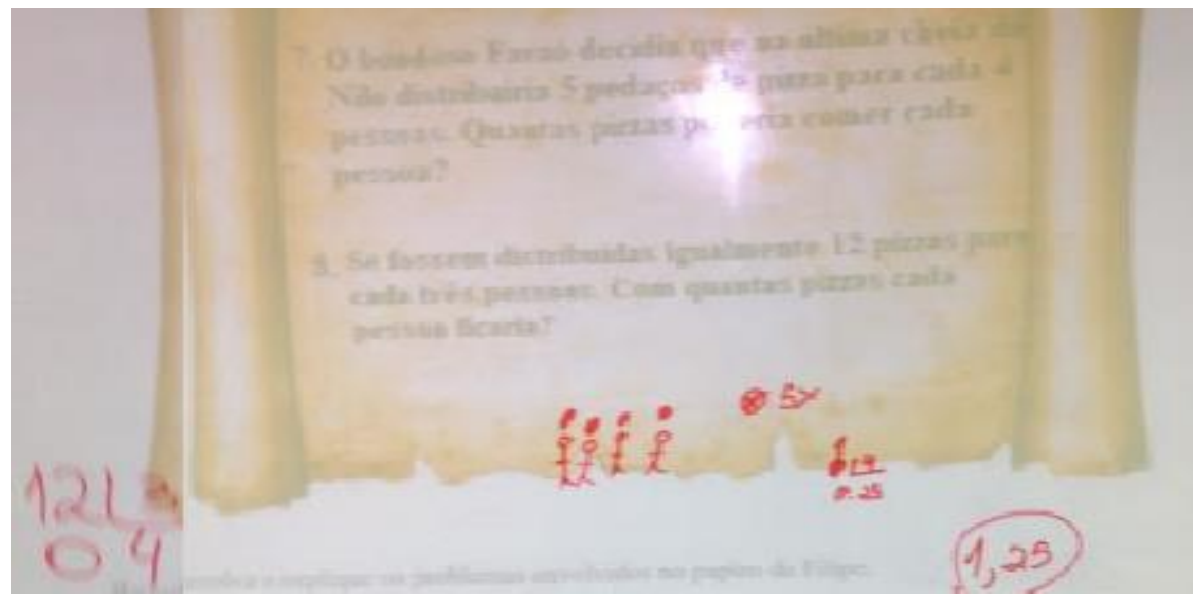

Fonte: Autor.

Para melhor fundamentarmos a resposta do aluno D faremos a descrição do áudio de sua resolução na lousa com participação dos outros alunos.

Aluno D - Então ó, tínha quatro pessoinhas, e tinha cinco pedaços de pizza, vamos distribuir um pedaço de pizza para cada, aí sobra um pedacinho de pizza, ai você vai dividir esse pedacinho em quatro partes, ai vai dar um quarto.

Tinha 12 pizzas para as três pessoas você divide aí da quatro, então são quatro pizzas para cada uma das três pessoas.

Durante a discussão e a apresentação da resposta os alunos se envolveram bastante, mostrando seu raciocínio e tentando colocar em prática o que haviam pensando para resolver cada questão.

\section{Questão9}

Como mencionado na metodologia a questão 9 visa discutir o conceito de razão através de um problema que motive os alunos a pensar. Essa questão foi extraída dos estudos de Silva (2005) e modificada para fazer parte da narrativa desenvolvida na sequência didática. A questão gerou muitas dúvidas dos alunos por causa do nome 
"escala" que aparece no enunciado. Veremos algumas resoluções propostas pelos alunos nas imagens que seguirão.

Figura 56 - Resolução da questão 9 - Aluno $G$

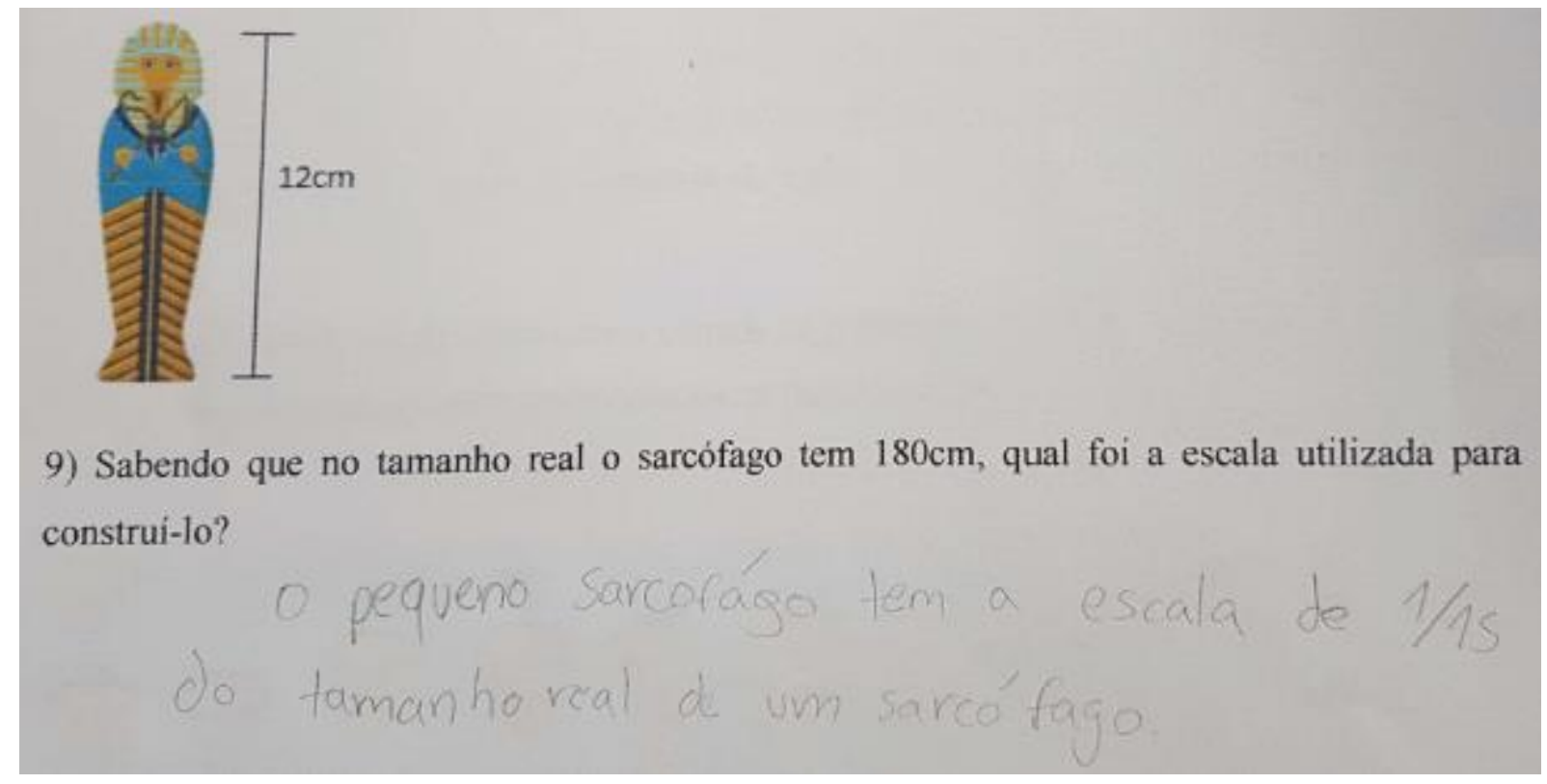

Fonte: Autor

Para resolver a essa questão os alunos fizeram um procedimento parecido, eles queriam dividir e comparar tamanhos para descobrir a escala. $\mathrm{O}$ aluno $\mathrm{G}$, por exemplo, em sua resolução do exercício faz uso da razão de um para quinze como podemos ver na imagem acima. Ele não escreve a palavra razão diretamente, mas pela resposta escrita do aluno podemos verificar que o mesmo fazia bom uso da ideia de razão sem mencionar o nome razão. Agora mostraremos outra resolução da mesma questão proposta pelo aluno F, conforme a imagem abaixo. 
Figura 57 - Resolução da questão 9 - Aluno F

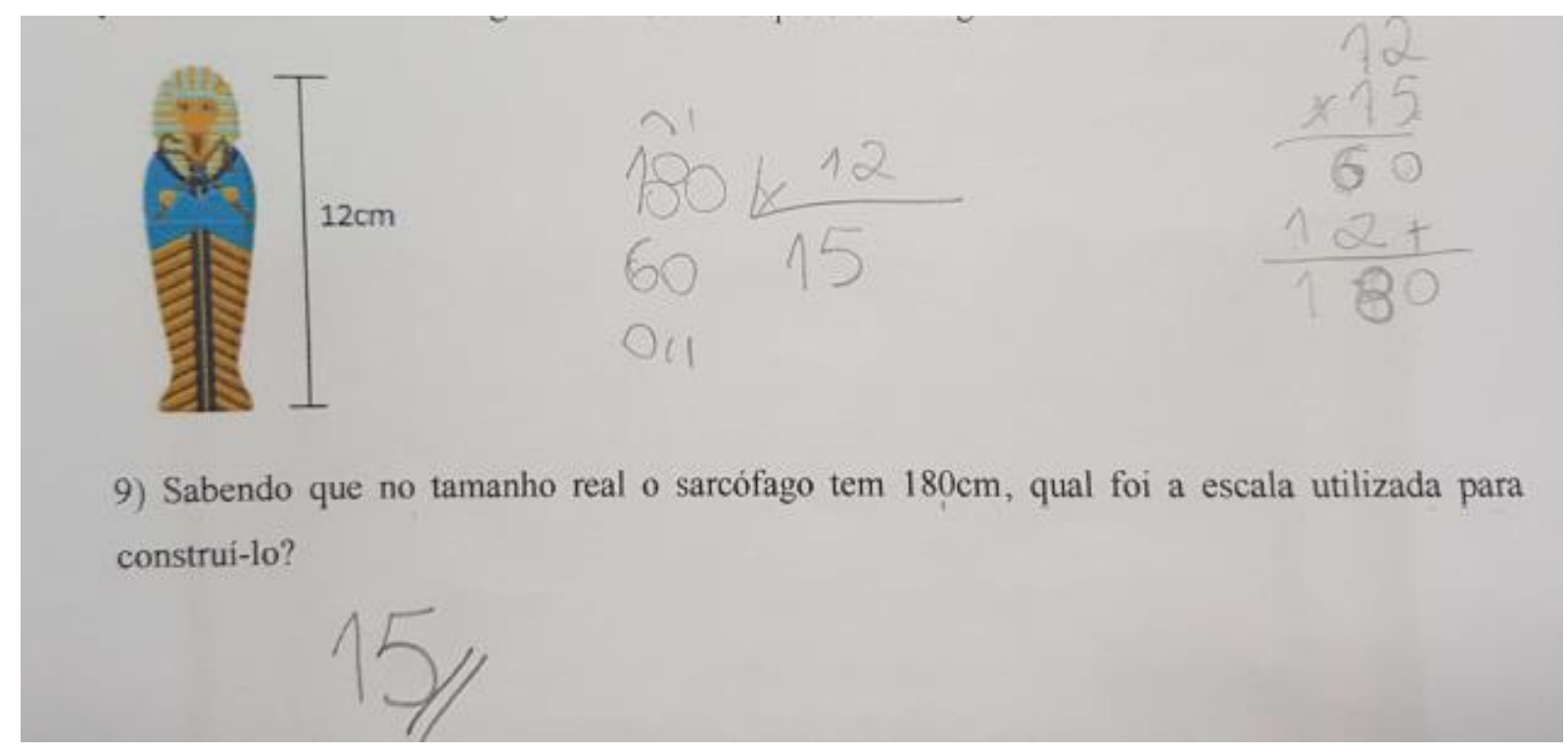

Fonte: Autor

Diferente do aluno G, o aluno F fez uma divisão entre os números presentes no enunciado da questão e o resultado dessa divisão deveria ser a resposta a pergunta, que no caso foi a resposta de 15 . O aluno não apresentou mais razões para a sua resposta, ficando assim para iniciar as discussões em grupo.

\section{Discussão da questão 9}

Como a questão 9 trouxe para a sala de aula um nome que até então parecia desconhecido para muitos alunos, ela trouxe também muita discussão em grupos por parte dos alunos. Após fazer a divisão dos grupos, os alunos começaram a discutir e pensar uma resposta única em um período de 10 minutos. Durante esse tempo notamos a importância em determinar alguns nomes antes de passar uma questão que o contenha, ou, omitir esse nome para que não causasse tantas confusões na resolução da questão. Depois da discussão em grupos um aluno foi até a lousa para explicar o seu raciocínio e tentar convencer a sala de aula do seu pensamento. Abaixo mostramos a descrição do áudio da resolução da questão 9 na lousa pelo aluno G.

Aluno G - O normal dele é $180 \mathrm{~cm}$, então como o tamanho do pequeno é $12 \mathrm{~cm}$, então a gente divide para saber quantas vezes o 12 vai caber no 180. Então a escala é, a escala do pequeno é essa. 
$\mathrm{O}$ aluno $\mathrm{G}$ desenvolveu de maneira clara a sua resposta e conseguiu fazer com que seus colegas também compreendessem o que ele estava explicando.

\section{Questão 10}

A última questão da sequência também foi retirada dos estudos de Silva (2005) e tinha como objetivo incentivar o aluno a pensar sobre o conceito de operador dentro de frações em que o aluno deveria transformar grandezas pela ação de dois operadores fracionários. Os alunos deveriam então buscar a solução através de uma operação entre frações.

Mostramos abaixo algumas imagens contendo soluções dos alunos.

Figura 58 - Resolução da quesgtão 10 - Aluno H

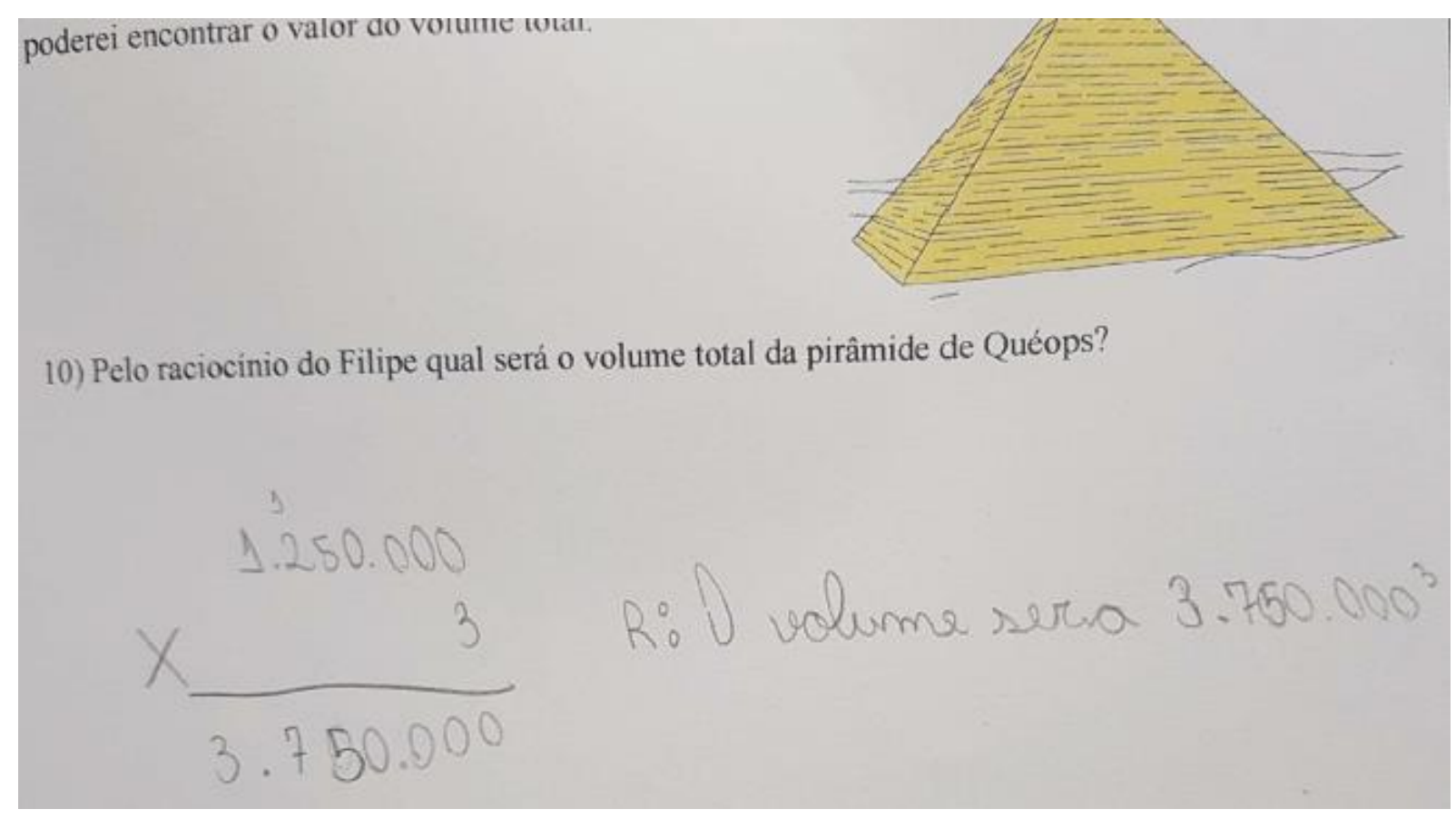

Fonte: Autor

Vemos na imagem acima que o aluno $\mathrm{H}$ desenvolveu sua resposta multiplicando o valor do enunciado por 3. Como no enunciado consta a informação de que o personagem sabia que o valor da terça parte do volume da pirâmide era $1.250 .000 \mathrm{~m}^{3}$, para encontrar o valor total bastaria pela resolução do aluno $\mathrm{H}$, multiplicar isso por 3 para obtermos o resultado da questão. Outros alunos seguiram raciocínios semelhantes ao do aluno $\mathrm{H}$, evidenciando a possibilidade de trabalharmos com mais questões que demandem esse tipo 
de raciocínio por parte dos alunos. Na imagem abaixo veremos a solução proposta pelo aluno L.

Figura 59 - Resolução da questão 10 - Aluno L

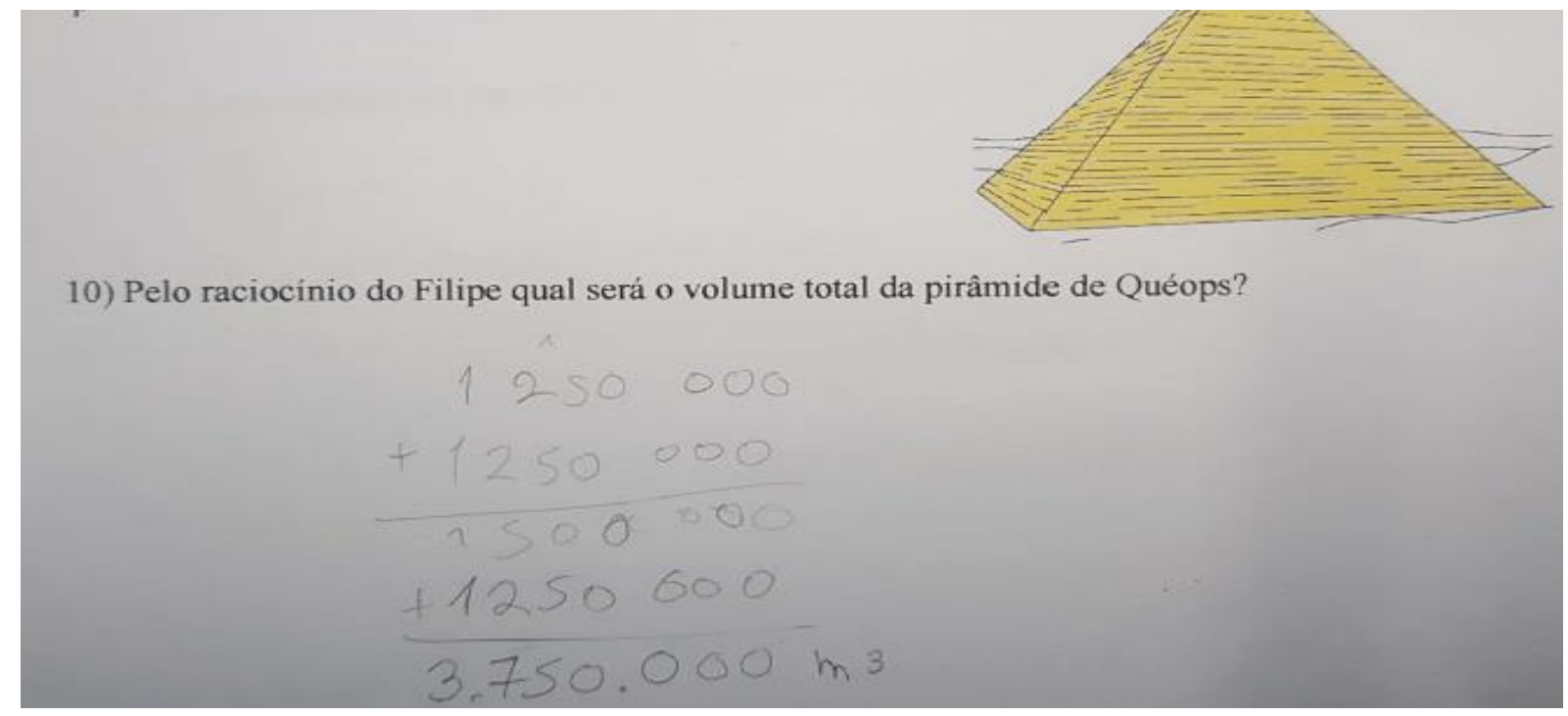

Fonte: Autor

Diferente do aluno H, o aluno L usa outro tipo de resolução da questão 10. Sabendo que o volume da terça parte da pirâmide era de $1.250 .000 \mathrm{~m}^{3}$, ele resolveu somar $\mathrm{o}$ valor de $1.250 .000 \mathrm{~m}^{3}$ três vezes para chegar ao resultado final. Na prática, a resposta terminou sendo a mesma, com raciocínio desenvolvido através de meios diferentes.

\section{Discussão da questão 10}

Na última questão da sequência didática os alunos tiveram menos tempo para fazer a discussão, eles sentaram-se em grupos de dois ou mais alunos e usaram um período de aproximadamente 4 minutos. Depois de discutirem em seus grupos a aluna L foi na lousa fazer a resolução do exercício 10. Mostraremos a descrição do áudio da resolução da aluna L, bem como a participação dos alunos na resolução da questão.

Aluna L - Eu dividi esse número por 3.

Aluno S - Multiplicar, multiplicar.

Aluno B - Não era só multiplicar por 3? 
Aluna L - Eu multipliquei esse número por 3. A aluna L havia respondido da maneira correta o exercício 10 , mas na hora em que teve que explicar seu raciocínio na lousa ficou nervosa e confundiu a forma como havia construído a sua resposta. 


\section{CONSIDERAÇÕES FINAIS}

Buscamos através desse estudo aplicar uma sequência didática no fundamental II com uso de contextualizações com narrativas históricas que pudessem motivar o aluno a partir para a situação de ação utilizando as ideias da teoria das situações didáticas, propostas por Guy Brousseau, juntamente com algumas questões dos estudos já realizados por Silva (2005). Através das pesquisas históricas que foram desenvolvidas nesse estudo, percebemos algumas ideias para criar narrativas históricas em que possamos de alguma forma trazer para o aluno as relações da construção do conhecimento de frações que já existia muito antes do que eles poderiam imaginar.

Entre erros e acertos, aprendemos que é muito importante que o aluno possa desenvolver o seu pensamento, descrever o seu raciocínio, estando certo ou não. Os momentos em que os alunos precisariam fazer uso das fases das situações didáticas propostas por BROUSSEU (2008) (devolução, ação, formulação, validação e institucionalização) foram realizados, mas acreditamos que a fase da institucionalização acabou sendo prejudicada devido ao tempo das aulas e a alguns prazos decorrentes do dia a dia de uma escola.

A sequência didática foi um elemento motivador para os alunos, eles se envolveram prontamente e tentaram resolver os problemas da narrativa histórica que foi apresentada. Assim percebemos que o uso de narrativas contribui bastante como fator de motivação dos alunos, e que é importante que os professores construam narrativas para motivar os alunos a participar da resolução dos problemas propostos em uma aula ou até mesmo em uma sequência.

As frações têm uma linda história construída, que não é utilizada em sala de aula. Acreditamos que os professores possam buscar elementos históricos para construir narrativas e assim levar para os alunos histórias encantadoras com desafios que os motivem e os façam perceber aos poucos a importância da matemática em seu cotidiano.

Concluímos, assim, que é possível criar uma sequência didática baseada em uma narrativa com elementos históricos que contribua para a motivação dos alunos e para seu aprendizado. 


\section{REFERÊNCIA BIBLIOGRÁFICA}

ALMEIDA, M. Origens da Matemática - Vol. 2: A Pré-História da Matemática - O Neolítico e o Alvorecer da História. Parana: Progressiva, 2011.

BARTHÉlemy, G. 2500 Anos de Matemática. São Paulo: Instituto Piaget, 1999.

BECK, Vinicius Carvalho . A matemática no Egito Antigo. Artigo acadêmico, 2015.

BEZERRA, F. Introdução do Conceito de Número Fracionário e de suas Representações: Uma abordagem criativa para a sala de aula. 2001. Dissertação (Mestrado em Matemática). Pontificia Unuversidade Católica. São Paulo.

BOYER, Carl B. História da matemática. São Paulo: Edgard Blücher, 2010.

BRASIL. Ministério da Educação. Base Nacional Comum Curricular: Matemática do Ensino. Brasília. Ano?

BRASIL. Ministério da Educação. Guia de Livros Didáticos PNLD 2015 Ensino Médio: Matemática. Brasília: MEC, 2015.

BRASIL. Ministério da Educação. Secretaria de Educação. Média e Tecnológica. Parâmetros Curriculares Nacionais (Ensino Médio). Brasília: MEC, 2000.

Brolezzi e Monteiro. Números para quê? Governo do Estado de São Paulo. 2003.

Cervantes, M. B. P. de. Uma formação continuada sobre as frações. São Paulo: UNIBAN, 2010.

ClARAS, A. F.; PINTO, N. B. O Movimento Da Matemática Moderna E As Iniciativas De Formação Docente (Anais). Guarulhos: Educere, 2008.

CROSBY, Alfred W. A mensuração da realidade: a quantificação e a sociedade ocidental. Tradução de Vera Ribeiro. São Paulo: UNESP, 1999.

DIRK, J. Struik. História concisa das matemáticas. Lisboa: Gradiva, 1997. 
DRUCK, I. F. Frações: Uma análise de dificuldades conceituais. Instituto de Matemática e Estatística, São Paulo: USP, 2004.

DUVAL, R. Registres de representation sémiotique et fonctionnement cognitif de la pensée. Annales de Didactique et de Sciences Cognitives 5. IREM de Strasbourg, 1993.

EIGENHEER, Bertoni; Nilza. A Construção do Conhecimento sobre Número Fracionário. São Paulo: Estatística, 1994 e 2005.

FERNANDES, Nilga Velloso. Didática Um Instrumento Necessário. Rio de Janeiro. (editora?) 2001.

GILLINGS, R. Mathematics in the time of the pharaohs. New York: Dover Publications, 1982.

HILTON, P. Do We Still Need Fractions in the Elementary Curriculum? In: Proceedings of the IV International Congress on Mathematical Education. Boston: Birkhäuser, pp. 37-41, 1980.

HOGBEN, Lancelot. Maravilhas da Matemática: Influência e Função da Matemática nos Conhecimentos Humanos. V.1. São Paulo: Globo, 1958.

JESS, L. C. Frações em um livro didático na $5^{\mathbf{a}}$ e $6^{\mathbf{a}}$ séries: Uma aproximação através da história da Matemática. 2004. Dissertação (Mestrado em Educação) Universidade Federeal do Paraná. Curitiba.

KIEREN, T. On the mathematical, cognitive, and instructional foundations of rational numbers. In R. Lesh (ed.) Number and measurement: Paper from a research workshop. Columbus, Ohio: ERIC/MEAC, 1975.

MACHADO, N. J. Matemática e educação: alegorias, tecnologias, jogo, poesia. In Nilson José Machado. (Coleção questões da nossa época ; v.43). 6. ed. São Paulo: Cortez, 2012.

MERLINI, V. L. O conceito de fração em seus diferentes significados: um estudo diagnóstico com alunos de $5^{\mathrm{a}}$ e $6^{\mathrm{a}}$ séries do Ensino Fundamental. 2005. Dissertação (Mestrado em Matemática) São Paulo: Pontifícia Universidade Católica de São Paulo. 
MIORIM, M. A. O Ensino de Matemática: Evolução e Modernização. 1995. Tese (Doutorado em Matemática). Faculdade de Educação. Instituto de Computação. Universidade de Campinas - Unicamp. Campinas..

MLODINOW, Leonard. A Janela de Euclides: a história da geometria das linhas paralelas ao hiperespaço. Tradução de Enézio E. de Almeida Filho. São Paulo: Geração Editorial, 2008.

MORAIS, Erica Siani. Heródoto e o Egito: tradução e comentário do livro das Histórias I. Campinas: [s.e.], 1999.

MOUTINHO, L. V. Fração e seus diferentes significados: um estudo com alunos das $4^{\text {a }}$ e $8^{a}$ séries do ensino fundamental. 2005. Dissertação (Mestrado em Matemática). Pontifícia Universidade Católica. São Paulo.

NUNES, T. Diferentes Significados de Frações e sua Influência sobre o ensino e a aprendizagem. Anais do $8^{\circ}$ Encontro Nacional de Educação Matemática. Recife: Sociedade Brasileira de Educação Matemática, 2004.

NUNES, T. et al. Educação Matemática: números e operações. São Paulo: Cortez, 2005.

NUNES, T.; Bryant, P. Crianças fazendo matemática. Porto Alegre: Artes Médicas, 1997.

OLIVEIRA, Tatiana Laiz Freitas da Fonseca de. História do sistema de numeração. Curitiba, Monografia, Universidade Tuiuti do Paraná, 2004.

PAIS, L. C. Didática da Matemática: uma análise da influência francesa. Belo Horizonte: Autêntica, 2002.

PIRES, C. M. C. Currículos de Matemática: da organização linear à ideia de rede. FTD: São Paulo, 2000.

POLIGICCHIO, A. G. Teatro: materialização da narrativa matemática. 2011. 148 f. Dissertação (Mestrado - Programa de Pós-Graduação em Educação. Área de Concentração: Ensino de Ciências e Matemática) - Universidade de São Paulo, 2011. 
POMMER, M. W. 2008, Brousseau e a ideia de Situação Didática, SEMA, São Paulo, Brasil. Ano 2008.

PONTE, J. P. Investigar, ensinar e aprender. Actas do ProfMat 2003 (CD-ROM, pp. 25-39). Lisboa: APM, 2003.

PONTE, João Pedro da; BROCARDO, Joana; OLIVEIRA, Hélia. Investigações Matemáticas na Sala de Aula. Belo Horizonte: Autêntica, 2003.

ROQUE, T. História da Matemática: uma visão crítica, desfazendo mitos e lendas. Rio de Janeirio: Zahar, 2012.

SANTOS, A. O conceito de fração em seus diferentes significados: um estudo diagnóstico junto a professores que atuam no Ensino Fundamental. 2005. Dissertação (Mestrado em Matemática). Pontifícia Universidade Católica. São Paulo.

SCHONFELD, Alan. What Do We Know About Mathematics Curricula? Journal of Mathematical Behavior 13, 1994.

SILVA, M. J. F. Investigando saberes de professores do ensino Fundamental com enfoque em números fracionários para a quinta série. 301 f. Tese de doutorado. PUC/SP, São Paulo, Brasil, 2005.

SILVA, M. J. F.; ALMOUlOUD, S. A. As Operações com Números Racionais e seus Significados a partir da Concepção Parte-todo. Rio Claro: BOLEMA, 2008.

SMITH, David Eugene. History of Mathematics. v. 1. Boston: Ginn and Co, 1925.

SOUZA M. L V. Fração E Seus Diferentes Significados. In Anais do VII encontro paulista de educação matemática (VII) São Paulo: EMEP, data ?

STRUIK, D.J. História concisa da matemática. Lisboa: Gradiva, 1992.

TEIXEIRA, A. M. O professor, o ensino de fração e o livro didático: um estudo investigativo. 2008. Dissertação (Mestrado em Educação / Matemática) - Pontifícia Universidade Católica. São Paulo. 
VIANNA, Carlos Roberto. A hora da fração: pequena sociologia dos vampiros na educação matemática. Bolema, Rio Claro: São Paulo, ano 21, n 31, pp.161-181, 2008.

ZABAlA, A. A Prática Educativa: Como Ensinar.Porto Alegre: Editora Artmed, 1998.

\section{Bibiografia eletrônica}

ABNT, Associação Brasileira de Normas Técnicas, 1977 - Arredondamento. Disponível em: < http:/www.ebah.com.br/content/ABAAAgPAwAD/abnt-nbr-58911977>. Acesso: 05/07/2017 ás 15:00.

BARASUOL, Fabiana Fagundes. A matemática da pré-história ao antigo Egito. UNIrevista. Minas Gerais. v.1, n. 2, abril. 2006. Disponível em: < http://www.unirevista.unisinos.br/_pdf/UNIrev_Barasuol.pdf>. Acesso em: Ago, 2014.

BOSE, A. Did you know: The history of Egyptian mathematics - Part II. 2016. Disponível em: < http://arindambose.com/?p=737> . Acesso em 05/02/2017

BRASIL. Base Nacional Comum Curricular, textos introdutórios. Disponível em: < http://basenacionalcomum.mec.gov.br/\#/site/conhecaTextosIntrodutorios>. Acesso em 28 Jan 2015.

CAMISA, E. 2014 - Cálculo da taxa PTAX. Disponível em: <http://slideplayer.com.br/slide/3654202/> Acessado: 05/07/2017 ás 16h00.

FAZENDA, S. 2002. Notas do Tesouro Nacional - Disponível em: <http://www.tesouro.fazenda.gov.br/documents/10180/378339/Metodologia+de+C\%EF \%BF\%BDlculo.pdf/9667c47f-b247-4e17-b2cd-2992f0381d69 Acessado dia 02/02/2017.>Acesso: 05/07/2017 ás 18h00. 
FORTUNA, M. E. 2016. Um em cada três postos da capital já aumentaram o preço dos combustíveis. Disponível em: <https://gauchazh.clicrbs.com.br/portoalegre/noticia/2016/01/um-em-cada-tres-postos-da-capital-ja-aumentou-preco-dagasolina-cj5w6oohq1dpjxbj00ta67jkb.html. > Acesso em: 05/07/2017

GERONIMO, Rafael Rix; FUMIKAZU, Saito. O papiro de Rhind: um estudo preliminar. Revista de produção discente em educação matemática. São Paulo. v.1, n. 1, 2012. Disponível em: <http://revistas.pucsp.br/index.php/pdemat/article/view/9228/6847>. Acesso em: 23 Jun, 2016.

HISTÓRIA DO MUNDO. http://historiadomundo.uol.com.br/arabe/arabes.htm

LOPES, A. J. (2004) Reflexões sobre o ensino de frações no currículo de matemática. Disponível em: <http://www.matematicahoje.com.br/telas/autor/artigos/. Acesso em: Ago. 2008.

LUCHETTA, J. O. V. (2008) Papiro Rhind. Disponível em <http://www.matematica.br/historia/prhind.html >.

LUMA, V. (2012). Receita de bolo de chocolate. Disponível em: $<$ http://gshow.globo.com/receitas-gshow/receita/bolo-de-chocolate503e93bac5a64550c1000053.html> Acesso em: 05/08/2017 ás 19h27.

MAX, J. (2014) - Odômetro Volkswagen UP. Disponível em:< http://www.autorealidade.com.br/2014/02/as-impressoes-sobre-o-volkswagen-up.html> Acessado em: 28/06/2017 ás 17h56.

REIS, Clenilson dos; MIRANDA, Henrique S.; JACOBSEN, Simone. A história da matemática no Egito. Disponível em: < mtuliop.googlepages.com/Egito.pdf.>. Acesso em: 19 Jul. 2008. 
ROQUE, C. Resumo dos PCN. Disponível em: < https://rcolacique.files.wordpress.com/2012/02/parc3a2metros-curriculares-nacionaisresumo.pdf>. Acesso em: 14 Jul. 2016.

SECOM, M. C. (2014). Manual de Comunicação da Secom. Disponível em: <https://www12.senado.leg.br/manualdecomunicacao/redacao-e-estilo/estilo/numero> Acessado: 21/05/2017 ás 17 h00.

VICTORIA, L. (2012). Receita de bolo de chocolate. Disponível em: <http://gshow.globo.com/receitas-gshow/receita/bolo-de-chocolate-503e93bac5a64550c1000053.html> Acesso em: 07/05/2017 ás 21h00.

WIKIMEDIA. $\quad 322 . \quad$ Plimpton. Disponível $<$ http://www.math.ubc.ca/ cass/courses/m446-03/pl322/pl322.htm>. Acesso em 09/08/2017. 1800 BCE.

WIKIPEDIA. François Viéte. Flórida: Wikimedia Foundation, 2017. Disponível em: <https://pt.wikipedia.org/w/index.php?title=Fran\%C3\%A7ois_Vi\%C3\%A8te\&oldid=4 9676827>. Acesso em: 25 ago. 2017.

WIKIQUOTE. Simon Stevin. (2017, October 6). Wikiquot. Disponível em: <https://en.wikiquote.org/w/index.php?title=Simon_Stevin\&oldid=2299289.> Acessado em 01/09/2017

WOLFRAMALPHA, (2017). Cálculo de um sistema de equações. Disponível em: http://www.wolframalpha.com . Acessado em 09/08/2017 - ás 12 h25.

YALE. Babilonian Colection. Ybc 7289 - S.a. Disponível em: < http://it.stlawu.edu/ dmelvill/mesomath/tablets/YBC7289.html > Acesso em 10/07/2017. 


\section{Anexos}

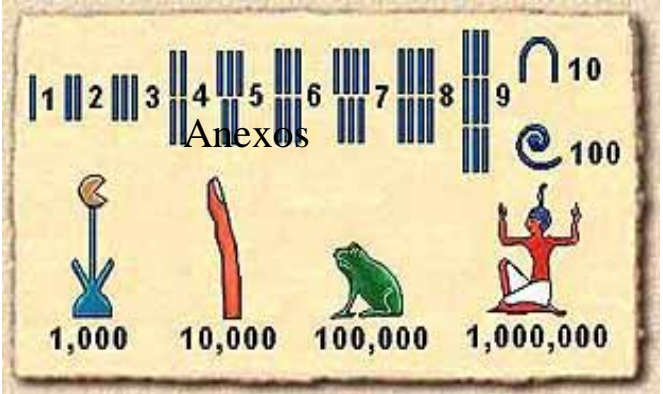

$\underline{\text { Por dentro das pirâmides do Egito }}$

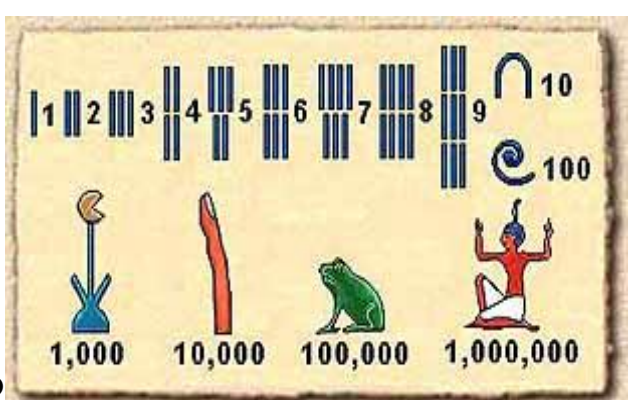

No dia 21 de dezembro de 2012, Filipe Raphael Mattos viajou para o Egito para conhecer as pirâmides pessoalmente e tirar suas conclusões. Filipe havia se formado em Arqueologia no ano de 2011 pela Universidade Federal do Maranhão (UFM) e gostaria de conhecer o mundo afora para colocar em prática o que havia aprendido na faculdade. Uma das coisas que mais intrigavam Filipe era a pirâmide de Quéops, ele acreditava que poderia encontrar mais segredos dentro da pirâmide do Egito e com isso mostrar a sua teoria pelo mundo.

Quando Filipe chegou próximo à entrada da pirâmide viu alguns sinais que chamaram a sua atenção, esses sinais estão representados na imagem abaixo.

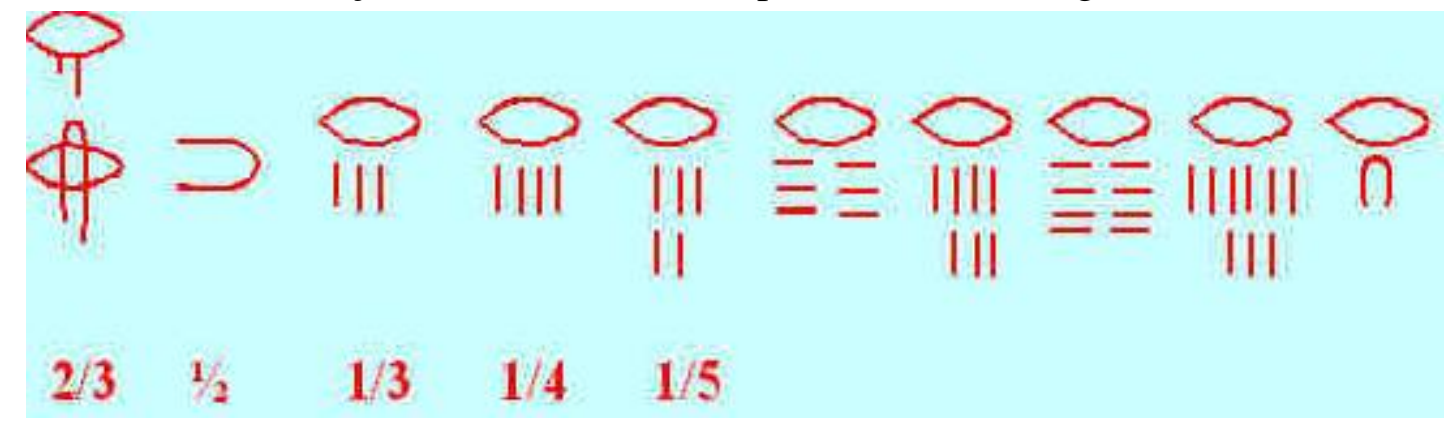

1) Tente explicar os padrões na imagem acima e completar o que falta na imagem.

Após sua entrada na pirâmide de Quéops Filipe percebeu uma imagem pequena no canto de uma das paredes que tinha alguns desenhos e uma frase escrita em árabe egípcio.
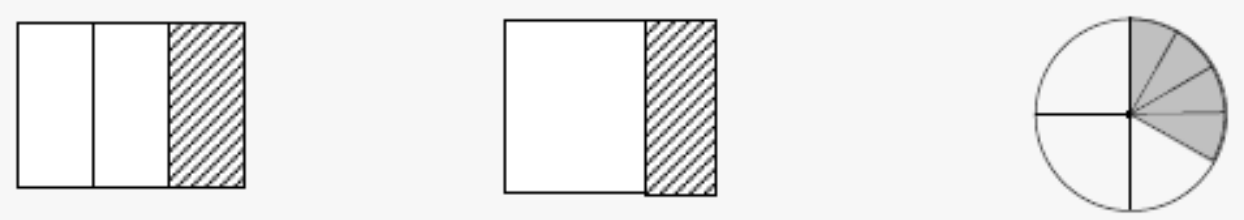

كل من يحلد الأرقام الكسرية في هذه الصورة قد تستمر من خلال أسعرار كيوبس. 
Como Filipe havia estudado muito as línguas antigas ele conseguiu entender o que estava escrito e fez a seguinte tradução "Quem identificar os números fracionários nessa imagem poderá continuar através dos segredos de Quéops”

2) Quais são os números fracionários que podemos identificar nessas imagens? Explique como chegou a essa conclusão.

Filipe acreditava que poderia desvendar mais coisas dentro da pirâmide de Quéops, por isso continuou caminhando tentando encontrar algo novo para sua pesquisa como arqueólogo. Olhando atentamente as paredes internas da pirâmide ele percebeu um detalhe que ninguém havia reparado, uma das imagens do lado de dentro da pirâmide estava incompleta, o desenho que estava aparecendo era somente um terço do desenho que deveria aparecer de fato. Sendo assim Filipe tirou uma foto da imagem e resolveu refazer o desenho para mostrar a todos a sua habilidade em reconstruir imagens antigas.

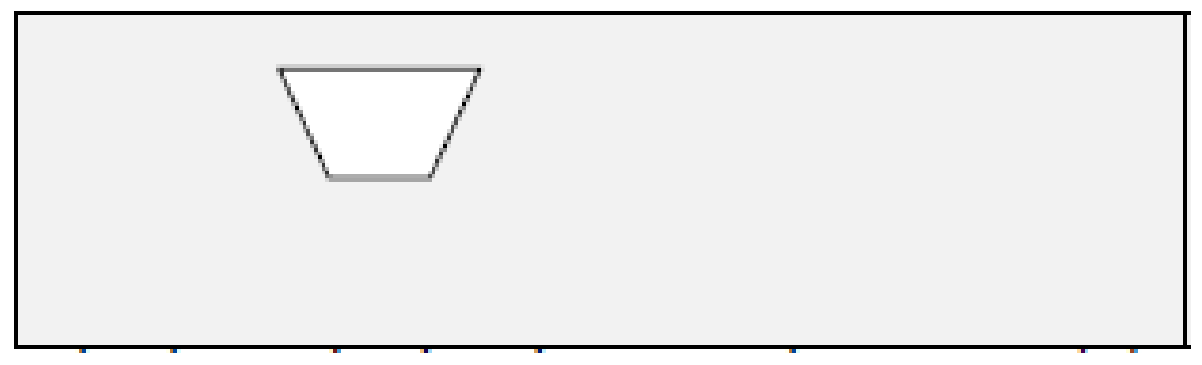

3) Se essa imagem tem um terço da imagem original, você deve completa-la para que ela volte a ter o tamanho original.

Filipe viu uma entrada estranha dentro da pirâmide, algo como um túnel que parecia ser em linha reta e levar a algum lugar desconhecido, ele não pensou duas vezes e resolveu se arriscar pelo caminho, dentro desse túnel haviam algumas marcações de distâncias que 
Filipe não conseguiu identificar. Essas marcações poderiam determinar o quanto Filipe já havia andado e o quanto faltava para ele andar. Observe os detalhes na imagem abaixo.

4) Considerando o tamanho total do túnel em que o Filipe estava, qual parte do caminho faltava ser percorrida pelo Filipe?

Chegando ao final do túnel Filipe encontrou mais um problema que precisava ser resolvido urgentemente. O Cetro do Faraó estava incompleto em seu desenho na parede dentro da pirâmide, ele acreditava que o tempo poderia ser a causa desse mal. Para que não ficasse faltando uma parte desse Cetro Filipe resolveu desenhar a parte que faltava, mas para isso ele precisaria da medida exata, pois não se pode errar com os Faraós.

5) Como Filipe calculou a parte que faltava para desenhar o Cetro?

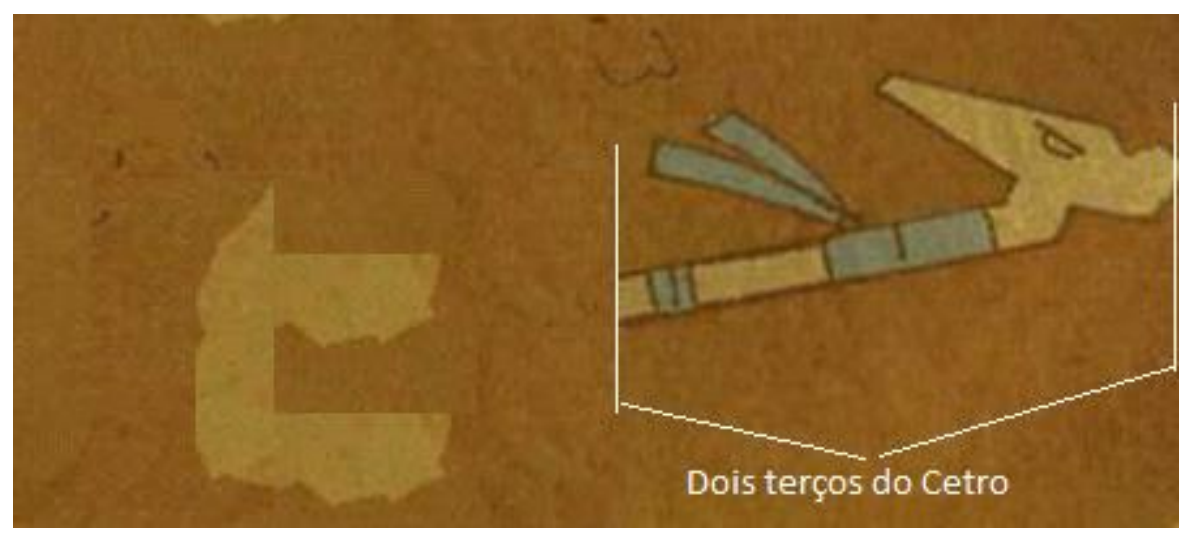

6) Desenhe o restante do Cetro que falta para que Filipe continue sua jornada pelas pirâmides do Egito.

Depois de quatro horas andando pela pirâmide Filipe resolveu sentar-se pois estava se sentindo cansado. Ele ficou imaginando a hora de contar para todos as descobertas que havia feito na pirâmide de Quéops. Enquanto pensava Filipe pensou ter visto um pedaço de papel jogado ao chão, mas na verdade o que ele realmente estava vendo era um papiro, ele ficou entusiasmado para ver o que havia escrito naquele papiro e para sua alegria no 
papiro tinham dois problemas que não tinham sido resolvidos pelos egípcios da época. Observe atentamente os problemas do papiro e tente resolvê-los.

Revolva e explique os problemas envolvidos no papiro de Filipe.

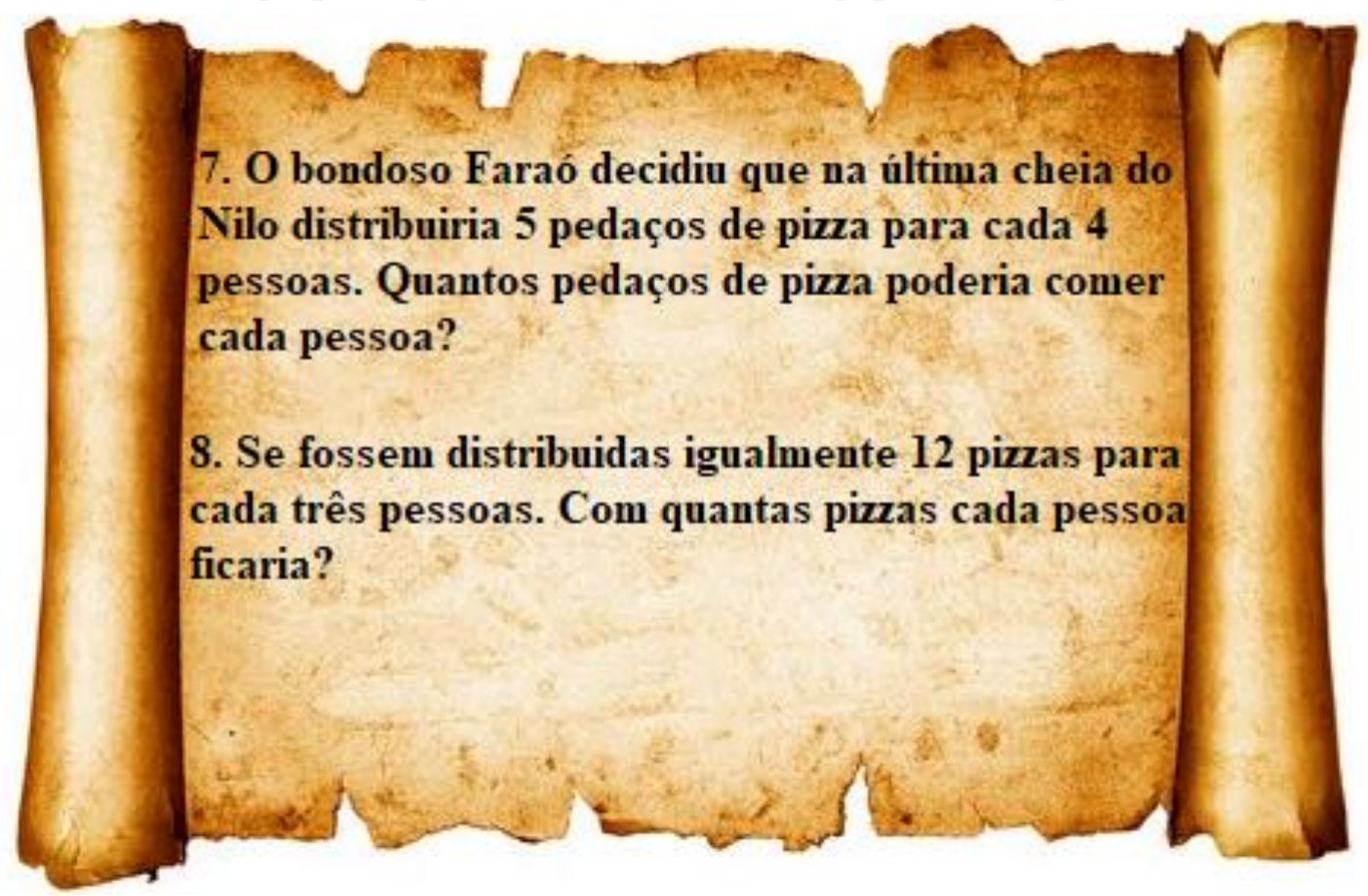

Depois de tantos problemas desafiadores, Filipe resolveu que deveria voltar para seu quarto de hotel e descansar, pois, ele ainda tem muitos lugares para conhecer e muitas coisas para descobrir. Na saída da pirâmide Filipe recebeu um pequeno sarcófago e ficou agradecido pelo presente. Ele tirou uma régua do bolso e viu que o sarcófago tinha $12 \mathrm{~cm}$ de altura.

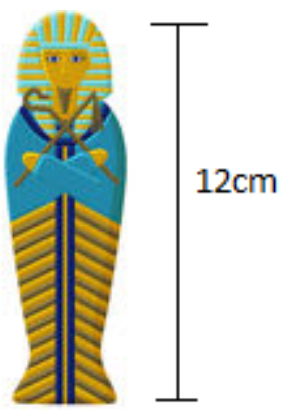

9) Sabendo que no tamanho real o sarcófago tem $180 \mathrm{~cm}$, qual foi a escala utilizada para construí-lo? 
No caminho para o hotel Filipe estava pensando em qual seria o volume da pirâmide de Quéops, e se alguém já teria feito esse cálculo tão intrigante. Ele continuou pensando e tentou criar um raciocínio da seguinte maneira. Se um terço dessa pirâmide tiver o volume de $1.250 .000 \mathrm{~m}^{3}$ poderei encontrar o valor do volume total.

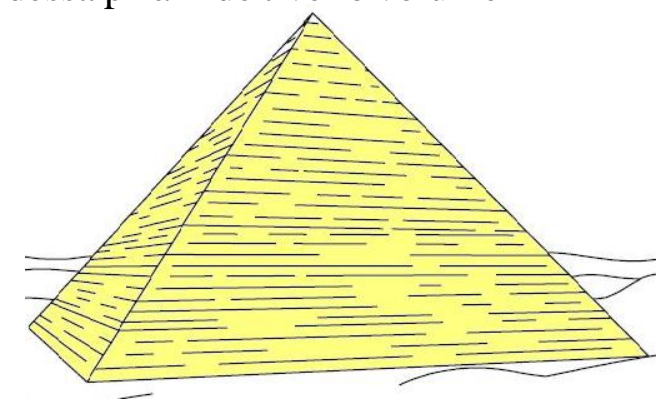

10) Pelo raciocínio do Filipe qual será o volume total da pirâmide de Quéops? 